This is a non peer-reviewed preprint submitted to EarthArxiv.

\title{
Decadal Evaluation of the AIRPACT Regional Air Quality Forecast System in the Pacific Northwest from 2009-2018
}

Jordan A. Munson ${ }^{1 \#, ~ J o e ~ V a u g h a n ~}{ }^{1}$, Brian Lamb ${ }^{1}$, and Yunha Lee ${ }^{1 *}$

${ }^{1}$ Laboratory for Atmospheric Research Civil and Environmental Engineering, Washington

5 State University, Pullman, 99163, United States

\#now at Wisconsin Department of Natural Resources, Madison, WI 53707-7921

*now at Center for Advanced Systems Understanding, Helmholtz-Zentrum Dresden-

Rossendorf, Dresden, Germany

10

Correspondence to: Yunha Lee (y.lee@hzdr.de)

Abstract. The Air Indicator Report for Public Awareness and Community Tracking (AIRPACT) is a comprehensive, automated air quality forecast system that provides 48-hr in-advance air quality over the Pacific Northwest region (http://lar.wsu.edu/airpact/). Since

15 2001, the AIRPACT forecasting system has been successfully operated by Washington State University, with the financial support from the Northwest International Air Quality and Environmental Science consortium (NW-AIRQUEST). AIRPACT consists of the Sparse Matrix Operator Kernel Emissions (SMOKE) model to provide temporal and spatial emissions, the Community Multiscale Air Quality (CMAQ) model to simulate hourly ozone, particulate

20 matter and related precursor concentrations over the Pacific Northwest region, and the Weather Research and Forecasting (WRF) model to simulate meteorology fields which are inputs for CMAQ: WRF is run by University of Washington and their outputs are transferred to Washington State University. AIRPACT is one of the longest operational regional air quality forecast system in the US that is based on a chemical transport modeling. In this

25 paper, we have evaluated AIRPACT forecasts for the last ten years (2009-2018) against quality-controlled EPA Air Quality System observations, with particular focus on examining how overall air quality forecast skill has changed as the AIRPACT system has evolved. During this period, AIRPACT has been intermittently updated with improved physical and chemical processes as well as newer emissions and higher resolution model domains. Our evaluation

30 results show that AIRPACT's skill at forecasting ozone $\left(\mathrm{O}_{3}\right)$ has improved over time. However, the fine particulate matter $\left(\mathrm{PM}_{2.5}\right)$, forecast performance has decreased over time. 
This is a non peer-reviewed preprint submitted to EarthArxiv.

The $\mathrm{PM}_{2.5}$ forecasts in the most recent version of AIRPACT were underpredicted to a larger degree than the previous version, partly because elevated $\mathrm{PM}_{2.5}$ concentrations during the wildfire season in the years 2015 and 2018 were underestimated. In order to improve overall air quality forecast accuracy, our future efforts should focus on building a more

5 reliable forecast system to handle extreme air quality events in combination with using new techniques for data-assimilation, ensemble forecasting, and statistical post-processing. 
This is a non peer-reviewed preprint submitted to EarthArxiv.

\section{Introduction}

Ambient air pollution is responsible for almost 3 million deaths each year globally, making it a major concern for public health (WHO, 2016). In recent years, air pollution has received public attention, as many cities, particularly in developing countries, experienced dangerous

5 levels of air pollution that caused a serious health burden. In the US, air pollution has greatly improved over time due to the Clean Air Act (CAA) implemented by the U.S. Environmental Protection Agency (U.S. EPA) (U.S. EPA, 2015a). Regulatory policy has been controlling outdoor air pollution effectively; however, it is not realistic to eliminate air pollution entirely, and pollutants are transported in the ambient air for days or weeks (depending on the 10 species), which makes air pollution a global problem. Some pollutants can be harmful even at ambient concentrations, especially for sensitive groups such as children (Neidell, 2004). Therefore, to protect public health from outdoor air pollution more effectively, a proactive action, such as advising a sensitive population group about upcoming air quality information, might be necessary.

Ozone and particulate matter with a diameter less than $2.5 \mu \mathrm{m}\left(\mathrm{PM}_{2.5}\right)$, are criteria pollutants that are regulated under the CAA as their adverse health impact on the public. According to Fann et al. (2012), $\mathrm{PM}_{2.5}$ pollution was responsible for 130,000 deaths in 2005 within the U.S. and ozone pollution for 4,700 deaths. Informing the public with ozone and particulate matter forecasts would be a proactive step towards preventing sickness and death related to air pollution.

Since 2001, the Laboratory for Atmospheric Research at Washington State University has operated the AIRPACT (Air Indicator Report for Public Awareness and Community Tracking) air quality forecast system successfully for Pacific Northwest (PNW)(Mass et al., 2003; Vaughan et al., 2004; Mahmud, 2005; Chen, et al., 2008). Currently, the modeling

25 components in AIRPACT include the WRF (Weather Research and Forecasting) meteorology model, SMOKE (Sparse Matrix Operator Kernel for Emissions) emission processing tool, and CMAQ (Community Multiscale Air Quality) chemical transport model along with chemical boundary conditions provided via the NCAR Whole Atmosphere Community Climate Model (WACCM; https://www.acom.ucar.edu/waccm/forecast/): WRF-based meteorology 
This is a non peer-reviewed preprint submitted to EarthArxiv.

forecasts have been operated by Prof. Cliff Mass at University of Washington and delivered to Washington State University daily. NW-AIRQUEST (Northwest International Air Quality and Environmental Science consortium) has provided financial support to AIRPACT with the goal of protecting human health and other values by protecting air quality. NW-AIRQUEST is

5 a group including federal, state, local and tribal air quality agencies (e.g., US EPA Region 10, the WA Department of Ecology, the Oregon Department of Environmental Quality and the Idaho Department of Environmental Quality, and the Puget Sound Clean Air Agency, among others).

AIRPACT predicts several air pollutants including surface ozone and PM2.5 to 1)

10 assist state and local air quality managements to make short-term and long-term plans to improve air quality in their jurisdictions and 2) forewarn the public, especially during the extreme air pollution events such as wildfires, so that they can make informed decisions on their activities. Along with the surface air pollution levels, AIRPACT also reports hourly air pollutant emissions, chemical boundary conditions used in AIRPACT, and observations in

15 handy visualizations to enable the public to understand the information easily. All our AIRPACT products are freely available via our website (http://lar.wsu.edu/airpact/).

The PNW region experiences various air quality events including stratospheric ozone intrusions, primarily in spring, prescribed agricultural burning in spring and fall, wildfires in summer and fall, and residential wood burning in winter. Wildfire smoke causes notoriously

20 poor AQ during summers in the region. The PNW region is also influenced by long-range transport of air pollutants from Asia (Jaffe et al., 1999). Extreme air pollution events such as stratospheric ozone intrusion and wildfires makes air quality forecasting challenging. As AIRPACT is based a 3-D gridded air quality model, our forecasts are also subject to uncertainties in input datasets (e.g., emissions, chemical boundary conditions and 25 meteorology) and from parameterizations of sub-grid scale and complex physical and chemical processes. Thus, our group has constantly evaluated our forecasts against observations and have modified AIRPACT system to provide more accurate forecasts to the public. As a routine process, AIRPACT is evaluated daily against AIRNOW (pre-qualitycontrol) observations, and performance statistics are published online. AIRPACT underwent

30 more thorough evaluations against the surface observation networks and satellite products; 
This is a non peer-reviewed preprint submitted to EarthArxiv.

for example, Chen et al. (2008) evaluated the AIRPACT version 3 against EPA's Air Quality System observations (AQS), IMPROVES and SWACCA during August-November 2004; Herron-Thorpe et al. (2010) evaluated the tropospheric NO2 column of AIRPACT version 3 against the OMI/Aura satellite NO2 products from March 2007 to August 2008; and Herron-

5 Thorpe et al. (2014) performed a comprehensive evaluation of AIRPACT version 3 for the 2007 and 2008 wildfire season using a suite of surface and satellite observations (i.e., EPA's AQS, AQUA-MODIS aerosol optical depth, OMI tropospheric $\mathrm{NO}_{2}$, AIRS CO, and CALIOP aerosols). However, there has not been a long term, multi-year evaluation study using AIRPACT.

In this paper, we have evaluated AIRPACT ozone and $\mathrm{PM}_{2.5}$ forecasts from the last 10 years (2009 to 2018) against the EPA's AQS observations, with a primary focus on how the AIRPACT forecast skill has progressed as our modeling system went through the major updates. Our archived data is limited to hourly ozone and $\mathrm{PM}_{2.5}$ and basic meteorology data at EPA AQS sites, because we were not able to save all AIRPACT forecast products due to data

15 storage costs; each day of forecast data takes many gigabytes of space. The meteorology evaluation is provided in the supplementary materials as the evaluation is limited because of large gaps in meteorological output during 2009-2012.

During the 2009-2018 period, AIRPACT underwent two major updates: from version 3 (hereafter, AP-3) to version 4 (hereafter, AP-4) and to version 5 (hereafter, AP-5). Table 1

20 provides a summary of each AIRPACT version. Note that we provide only model version number for WRF, CMAQ, and SMOKE. Please refer the details of updates made to each model in the relevant developer group, using the version number. Given that each major AIRPACT update involved many minor updates and we have not maintained access to older AIRPACT models, our analysis is mainly focused on describing the changes in forecast skills among the

25 AIRPACT versions and, when possible, we provide a potential cause for such changes.

\section{The AIRPACT Air Quality Forecast System}

Our AIRPACT system simulates hourly $\mathrm{O}_{3}$ and PM2.5 and related precursor levels over the PNW region, and consists of WRF, SMOKE, and CMAQ. The WRF forecasts used in AIRPACT 
This is a non peer-reviewed preprint submitted to EarthArxiv.

are generated daily by the University of Washington (UW); the specific details of the WRF model setup are available at this website (https://atmos.washington.edu/wrfrt/info.html). With the completion of the WRF forecast at the UW, the MCIP (Meteorology-Chemistry Interface Processor) preprocessor is run to extract WRF output fields for transfer to WSU,

5 where the MCIP meteorology files are used as input both for SMOKE emissions processing and for CMAQ chemical transport model, which results in the AQ forecast. As supplementary information, we have provided the list of publications related to AIRPACT from Laboratory for Atmospheric Research, Washington State University.

The current version, AP-5, uses SMOKE v3.5.1, CMAQ v5.0.2, and WRF v3.7.1 over a 10 domain that includes the entirety of Washington, Oregon, and Idaho and the adjoining parts of Canada, western Montana, and small northern sections of California, Nevada, and Utah. The AP-5 modeling system is depicted in S-Fig. 1. The model horizontal grid spans 285 columns west to east, spans 258 rows south to north, with grid cells of $4 \mathrm{~km} \mathrm{x} 4 \mathrm{~km}$ and with 37 vertical layers, the lowest of which is $\sim 40$ meters deep. The AP-4 system used CMAQ

15 v4.7.1, SMOKE v2.7 and v3.5, and WRF v3.4.1 and v3.5. AP-4 used the same domain and horizontal grid as AP-5, but with only 21 vertical layers. The AP-3 system used CMAQ v4.6, SMOKE v2.1, and WRF v3.1.1 with $12 \mathrm{~km} \times 12 \mathrm{~km}$ grid cells and 21 vertical layers. AP-3 had a slightly larger domain that extended further north (see S-Fig. 2). The number of vertical layers in AP-5 was changed from 21 layers to 37 layers in order to better resolve the

20 tropopause and to better capture stratospheric ozone intrusion events. Note that the WRF meteorology from UW provided 37 vertical layers for AP-3 and AP-4, but layer collapsing in MCIP had condensed those to 21 layers for AIRPACT to control CMAQ computing time.

Throughout the last three versions of AIRPACT, the CMAQ model has been updated with an available newer version (see Table 1). One of the significant updates occurred in AP-

25 5, which uses 1) CMAQ 5.0.2 that has an improvement in particulate matter (PM) speciation (i.e., separated the old term "PMother" into 12 more PM categories) and 2) the carbon bond gas-phase mechanism (CB05) instead of SAPRC99. The latter change was based on the two main findings from Luechen et al. (2008): CB05 is faster than SAPRC99, which helps to reduce CMAQ computing time, and it tends to predict lower ozone concentrations than 30 SAPRC99 on average. AIRPACT with SAPRC99 tended to overpredict ozone values, so the 
This is a non peer-reviewed preprint submitted to EarthArxiv.

switch to CB05 was in part an attempt to reduce ozone overprediction.

The AIRPACT system includes a comprehensive set of emissions, including mobile, non-mobile, biogenic and fire sources, that account for spatial and temporal variation (see the details in Table 1). Different emissions types and inputs are combined and assigned to 5 grid cells using SMOKE. To handle mobile emissions, AIRPACT used the MOBILE6 model in AP-3 and in AP-4 but switched partway through AP-4 to MOVES. MOVES was developed in response to concerns from the National Research Council that the MOBILE6 model was insufficient and was designed to be more adaptive and easier to use (Koupal, Cumberworth, Michaels, Beardsley, \& Brzezinski, 2003); the EPA no longer uses MOBILE6 and no longer 10 accepts the use of that model for regulatory analysis. MOVES emissions are based on modes, which is a method within MOVES to characterize local emissions on a finer scale than the MOBILE6 vehicle emissions which are based solely on a regional patterns. Thus these modes in MOVES allow a finer definition of emissions (Beardsley, Warila, Dolce, \& Koupal, 2009). MOVES is the currently maintained model and gets updated with newer emissions and 15 activity data (U.S. EPA, 2016a).

Non-mobile emissions for AIRPACT are gathered from state emissions inventory reports and the National Emissions Inventory (NEI). The NEI is a product produced by the EPA that contains an estimate of criteria air pollutant emissions; a new NEI version is released every three years (U.S. EPA, 2015b). To maintain emissions up-to-date, the NEI

20 inventory used in AIRPACT has been updated when a newer NEI was released. States release their own emissions inventories which allow partial updates to emissions. AIRPACT currently uses the 2014 NEIv2 with some local modifications or updates provided by AIRQUEST member agencies.

For biogenic emissions, the Biogenic Emissions Inventory System (BEIS3) (Vukovich $25 \&$ Pierce, 2002) was used in AP-3 but it was replaced with the Model of Emissions of Gases and Aerosols from Nature (MEGAN) (Guenther et al., 2006) starting with AP-4. The dataset in the BEIS3 model used a 1-km grid and was normalized by season (Chen et al., 2008). The emissions factors used in BEIS3 were based on a land use cover database for North America. Although MEGAN is designed to be used as a global emissions model for terrestrial aerosols 
This is a non peer-reviewed preprint submitted to EarthArxiv.

and gases, we run MEGAN at 1-km resolution like BEIS3. According to Hogrefe et al., (2011), MEGAN can result in higher ozone concentrations because it predicts higher isoprene concentrations than BEIS3.

For wildfire emissions, AIRPACT has used the USDA Forest Service BlueSky systems.

5 The original process depended on the USDA Forest Service BlueSky forecasts, which provided wildfire emissions and plume rise directly to AIRPACT. Several years later, the BlueSky Framework was installed and operated independently, allowing multiple options as to how emissions would be generated; the Framework offers options for each of the various steps that determine fuels, consumption, timing, and finally emissions from fires (Larkin,

10 2016), resulting in CO, $\mathrm{PM}_{2.5}$, coarse PM, and heat flux projections. AIRPACT now uses the BlueSky Framework to acquire fire size and locations from SMARTFIRE, while emissions processing is streamlined through customized lookup tables and plume rise is calculated using the DEASCO3 method, which generates improved plume characterization.

BlueSky depends on SMARTFIRE (Satellite Mapping Automatic Reanalysis Tool for

15 Fire Incident Reconciliation) to characterize fires to be modeled. SMARTFIRE gathers fire information from NOAA's Hazard Mapping System (HMS) and fire perimeters from GeoMAC (Geospatial Multi- Agency Coordination, https://www.geomac.gov) and merges them into a compatible format (Larkin, 2016). Originally, SMARTFIRE also used wildfire Incident Status Report (ICS209) fire area; however, the electronic accessibility of ICS209 reports for

20 wildfires was transferred to an incompatible system (IRWIN). This has degraded the daily accuracy of SMARTFIRE results, especially when HMS misses fires in cloudy conditions.

As a forecast system, AIRPACT is constrained to using detected fires and thus must make assumptions. Detected fires are assumed to persist at their reported size for the twoday forecast, an assumption we refer to as 'persistence'; our inability to reflect fire

25 suppression, fire growth, or extinguishment by weather or fuel shortage, is a limitation.

\section{Results}

We have evaluated the AIRPACT surface ozone levels and surface $\mathrm{PM}_{2.5}$ concentrations at AQS sites during 2009-2018. We have also evaluated temperature, specific humidity, wind 
This is a non peer-reviewed preprint submitted to EarthArxiv.

speed and direction from WRF simulations from 2009-2018, but we present those results in S-Table 1 in the supplementary materials because of the large data gap in the archived meteorology data. We used daily maximum 8-hour average (DM8A) ozone levels and daily $24 \mathrm{hr}$ average $\mathrm{PM}_{2.5}$ concentrations in all the evaluations for this paper. For ozone and $\mathrm{PM}_{2.5}$

5 evaluation, we have categorized the AQS site by the location type (i.e., rural, suburban, or urban) in order to better capture any systematic forecast issues. We again note that this AIRPACT performance evaluation is limited to the common AQS sites for each species or variable, which means that if observations for a site are missing during any AIRPACT version, then we excluded that site. This reduces the number of monitoring sites, but it allows us to

10 make a fair comparison among different AIRPACT versions: total $26 \mathrm{AQS}$ sites for $\mathrm{O}_{3}$ and total 89 sites for PM2.5 (see S-Table 2 for the details of AQS sites used in this paper).

To evaluate the AIRPACT systems forecasting accuracy progress over the time span, we used several statistical measures including mean bias (MB), mean error (ME), root mean square error (RMSE), normalized mean bias (NMB), normalized mean error (NME),

15 fractional bias (FB), fractional error (FE), and correlation of determination $\left(\mathrm{r}^{2}\right)$. Although we present all these measures, we will mainly discuss meteorology evaluation using MB, RMSE or ME and ozone and PM2.5 evaluations using FB and FE, because of the benchmarks values available from those metrics: We obtained the benchmark values from Emery et al. (2001) for meteorology parameters and Thunis et al. (2011) for air quality parameters. Due to large

20 gaps in the AIRPACT MCIP archived data, especially from 2009 to 2012, the AP-3 period, we provide only a brief evaluation for the meteorology forecasts and their evaluation is moved to the supplementary material.

\subsection{Ozone evaluation}

Table 2 shows overall forecast performance by each AIRPACT version for DM8A ozone levels 25 at $26 \mathrm{AQS}$ sites where we have $\mathrm{O}_{3}$ measurements during the entire period (2009-2018) over the AIRPACT domain. The overall mean and $98^{\text {th }}$ percentile of measured DM8A $\mathrm{O}_{3}$ are 36 ppbv and 55 ppbv, while the forecast mean and $98^{\text {th }}$ percentile are 41 ppbv and 59 ppbv, respectively. The mean bias (MB) of AIRPACT $\mathrm{O}_{3}$ is 4.2 ppbv (fractional bias, $\mathrm{FB}$, of $12 \%$ ). Based on the goal benchmark value of $30 \%$ for FE and $\pm 15 \%$ for FB used by Thunis et al. 
This is a non peer-reviewed preprint submitted to EarthArxiv.

(2011), all versions of AIRPACT show satisfactory results. Comparing among the AIRPACT versions, AP-5 performed the best (MB of 2.6 ppbv and FB of 8.1\%) and AP-4 performed the worst (MB of 5.0 ppbv and FB of 14\%), however AP-4 shows the highest correlation of determination $\left(\mathrm{R}^{2}\right)$ value, 0.68 . From $\mathrm{AP}-3$ to $\mathrm{AP}-4$, most evaluation metrics values are quite

5 similar, which indicates reducing grid spacing from $12 \mathrm{~km}$ to $4 \mathrm{~km}$ did not help to improve $\mathrm{O}_{3}$ predictions. Updating to AP-5 shows noticeable improvements; all the bias terms are reduced by nearly a half and error terms are decreased by a few percent, even though the $A P-5$ version shows the lowest $\mathrm{R}^{2}$ value, 0.54 . Note that $\mathrm{O}_{3}$ evaluation at individual $A Q S$ site is presented in S-Table 3.

Figure 1 shows ratios of forecast to measured $\mathrm{DM} \mathrm{A} \mathrm{O}_{3}$ against the corresponding measured $\mathrm{O}_{3}$ levels at the $26 \mathrm{AQS}$ sites for each AIRPACT version. Note that a ratio of 1 means perfect agreement between the forecast and measurement. All AIRPACT versions performed well, mostly within a factor of two. AIRPACT shows better agreement in higher concentration regimes (over $30 \mathrm{ppbv}$ ) than in lower concentration regimes (below $30 \mathrm{ppbv}$ ). A systematic

15 overprediction in low concentration regimes was also reported by Chen et al. (2008), which evaluated the AIRPACT-3 during the two-month period (August and September) in 2004. This problem is also shown in other air quality models. For instance, the multi-model intercomparison study (i.e., Air Quality Model Evaluation International Initiative, AQMEII) on tropospheric ozone, presented by Im et al. (2015), found a similar systematic 20 overprediction in surface level ozone below $30 \mathrm{ppbv}$ from all participating air quality modeling systems over North America including WRF with CMAQ as is used in this study (see Figure 9b in Im et al., 2015).

To understand how AIRPACT's ability to forecast ozone has changed by seasons, we compared the observed and measured DM8A $\mathrm{O}_{3}$ distributions by season for each AIRPACT

25 version using a box plot (in Fig. 2). All AIRPACT versions overpredict $\mathrm{O}_{3}$ in all season, except for the AP-5 summer season (see the details of seasonal evaluation statistics in S-Table 4). The overprediction is worse during the low $\mathrm{O}_{3}$ season such as fall and winter (mean bias of 4.4-7.8 ppv with fractional bias of $13-26 \%$ ), compared to the high $\mathrm{O}_{3}$ seasons such as the spring and summer (mean bias of 2.1-5.5 ppbv with fractional bias of -4.5 to $12 \%$ ). The 30 systematic overprediction of $\mathrm{O}_{3}$ in the low concentration regime, shown in Fig. 1, should be 
This is a non peer-reviewed preprint submitted to EarthArxiv.

mostly from the fall and winter seasons, as their $\mathrm{O}_{3}$ levels are frequently below $30 \mathrm{ppbv}$. The observed highest $\mathrm{O}_{3}$ season is not well captured for all versions: AP-4 and AP-5 show the spring as the highest while the observation shows the summer; for AP-3 peaks during the summer while the observation during the spring.

Figure 3 shows the observed and simulated diurnal ozone profiles in summer for each AIRPACT version. All AIRPACT versions capture the observed diurnal patterns remarkably well $\left(R^{2}=0.94-0.96\right)$. The simulated max and min $O_{3}$ levels occurred at $1-2 \mathrm{pm}$ and 5-6 am, respectively, which are comparable to the observation within 1-2 hours difference. Our model peak time is earlier than the observation, which also occurs in other 3-D air quality modeling systems (see Figure $8 \mathrm{c}$ in Im et al., 2015). The simulated $\mathrm{O}_{3}$ max levels (45-49 ppbv) are simulated reasonably to the observation (43-47 ppbv), but our model tends to overpredict at other hours including the min levels, particularly worse during nighttime, by up to 10 ppbv. Unlike the summer $\mathrm{O}_{3}$ diurnal profiles, no AIRPACT versions capture well the observed diurnal patterns for winter season (see Fig. 4; $\mathrm{R}^{2}=0.11-0.20$ ) and all show severe

15 overprediction during nighttime up to $17 \mathrm{ppbv}$. AIRPACT shows the max $\mathrm{O}_{3}$ levels at $1 \mathrm{pm}$, which matches with the observation. However, the simulated min $\mathrm{O}_{3}$ levels peak at $5 \mathrm{pm}$ while the observed min levels peak at 6 am. The large gaps in nighttime $\mathrm{O}_{3}$ levels might be a common issue in air quality modeling as the multi-model inter-comparison studies by Im et al. (2015) and Solazzo et al. $(2012 ; 2013 a)$ also showed the same issue, which needs further

20 investigation into what causes such high $\mathrm{O}_{3}$ levels during the nighttime in winter.

It is important to understand what contributes to such large overprediction in low $\mathrm{O}_{3}$ regime in air quality models, but most studies have been focused on high $\mathrm{O}_{3}$ regime because a high $\mathrm{O}_{3}$ level is more of concern for air quality control managements and public health. Even though a further study is needed to find those contributing factors, we suspect that this 25 overprediction might be caused by the followings: 1) missing nighttime $\mathrm{NO}$ titration of $\mathrm{O}_{3}$, especially over urban areas where the observed 03 values often go zero but the models do not predict such low 03 values; 2) incorrect background level in the models; and 3) too weak boundary layer mixing at night.

To examine the forecast skills spatially for each AIRPACT version, the FB and FE 
This is a non peer-reviewed preprint submitted to EarthArxiv.

values of AIRPACT DM8A O $\mathrm{O}_{3}$ forecast performance are presented at individual AQS site in Fig. 5 and by sites grouped by location type (i.e., rural, suburban, and urban) in Fig. 6. To provide a clear picture of the overall change in FE from AP-3 to AP-5, we present the spatial distribution of FE difference in Fig. 7. The simulated DM8A $0_{3}$ levels at each AQS site span

5 from underestimates (down to the FB of $-9 \%$ ) to overestimates (up to the FB of 25\%) with the FE range of $10-35 \%$. Most sites show overprediction, which changed little by the AIRPACT versions. However, the updates made to AIRPACT over the decadal period does improve the forecast performance in several sites as shown in Figs. $6 \mathrm{f}$ and 7. The worst performance (highest FE) tends to occur at an urban site and the best performance (lowest

$10 \mathrm{FE}$ ) at a rural site, but we do not find any distinct difference in overall forecast performance for those groups. Figures $6 \mathrm{~d}$ and $6 \mathrm{e}$ show clearly that the model-to-observation agreement became worse from AP-3 to AP-4, despite the finer grid size applied in AP-4, and better from AP-4 to AP-5, likely because AP-5 adapted CB05 gas chemical mechanism that resulted in lower $\mathrm{O}_{3}$ level than the SAPRC mechanism and thus alleviated one $\mathrm{O}_{3}$ overprediction issue.

\section{$3.2 \quad \mathbf{P M}_{2.5}$ evaluation}

The evaluation statistical summary of AIRPACT daily $\mathrm{PM}_{2.5}$ forecasts at $89 \mathrm{AQS}$ sites for each AIRPACT version and entire 2009-2018 period are presented in Table 3. First of all, overall $\mathrm{PM}_{2.5}$ performance is roughly twice as poor compared to the overall $\mathrm{O}_{3}$ performance (e.g., the fractional error, $\mathrm{FE}$, of $\mathrm{O}_{3}$ and $\mathrm{PM}_{2.5}$ are $16 \%$ and $31 \%$, respectively). Over the major AIRPACT

20 updates, $\mathrm{PM}_{2.5}$ performance appears to get worse, unfortunately. For example, the FB of $\mathrm{PM}_{2.5}$ has been increased from $-4.5 \%$ to $-32 \%$, and for $\mathrm{FE}$, from $26 \%$ to $38 \%$. The coefficient of determination, $\mathrm{R}^{2}$, is above 0.5 for all versions except for AP-4. Even though AP- 5 shows the worst performance of $\mathrm{PM}_{2.5}$ compared to previous versions, it still meets the criteria benchmark of FB, which is $\pm 60 \%$. The AP- 3 and AP- 4 meet the goal benchmark of FB which

25 is $\pm 30 \%$. The PM2.5 evaluation at individual AQS site is presented in S-Table 5.

The ratios of forecast to measured daily $\mathrm{PM}_{2.5}$ concentrations against the corresponding measured concentrations for each version are shown in Fig. 8. The daily $\mathrm{PM}_{2.5}$ data points are rather equally distributed around 1 in AP-3 but started to move below 1 in the newer versions. AP-5 shows that many data points (shown as yellow colors in Fig. 8) are 
This is a non peer-reviewed preprint submitted to EarthArxiv.

noticeably below 1, which reflects an underprediction issue in that version. AP-5 also has several extremely poor forecasts (i.e., ratio $>3$ or ratio $<0.3$ ), especially for the regime of $\mathrm{PM}_{2.5}$ above $10 \mu \mathrm{g} \mathrm{m}^{-3}$.

Daily PM2.5 forecast skills by each season is presented in Fig. 9. Model $\mathrm{PM}_{2.5}$ is 5 generally underestimated in all seasons, particularly worse during summer. Based on the benchmark values, AP-3 performed well for all seasons (FB values $< \pm 30 \%$ ). AP-4 also meets the benchmark goal for all seasons except for summer that has the FB value of $-57 \%$. In the case of AP-5, fall and winter forecasts were good but spring and summer do not meet the benchmark goals (i.e., $-41 \%$ and $-70 \%$, respectively): summer does not even meet the criteria

10 benchmark value $( \pm 60 \%)$. The poor PM2.5 forecasts during summer seasons in AP-5 might be partly due to missing the large observed $\mathrm{PM}_{2.5}$ spikes during the summer of 2015 and 2018, which is shown in time series plots of monthly mean PM2.5 concentrations by AQS sites (grouped by rural, suburban, and urban) in S-Fig. 3. Air quality forecasts over PNW seem to be the most challenging during summer season (wildfire season in PNW) because

15 wildfires can result in large $\mathrm{PM}_{2.5}$ spikes and poor air quality in a region with otherwise good air quality: the area-burn time-series plot in S-Figure 4 shows the similar pattern as PM2.5, which indicates the influence of wildfires on the spikes.

To show how the $\mathrm{PM}_{2.5}$ forecast performed spatially for each AIRPACT major updates, we present the FB and FE values of daily $\mathrm{PM}_{2.5}$ evaluation in a spatial distribution (Fig. 10) 20 and in a scatter plot (Fig. 11). The spatial distribution of FE difference from AP-3 to AP-5 at individual site is shown in Fig. 12. AIRPACT $\mathrm{PM}_{2.5}$ performance ranges from underestimates (down to the FB of -126\%) to overestimates (up to the FB of 84\%), with the FE range of 32134\%. As shown in Fig. 10, it tends to underpredict daily $\mathrm{PM}_{2.5}$ across the model domain, particularly at rural areas. Unlike $\mathrm{O}_{3}$, the daily $\mathrm{PM}_{2.5}$ performance shows a distinct difference

25 in overall forecast performance by site location type: rural (total 25 sites), suburban (total 34 sites), and urban (total 30 sites). The sites showing overestimates are primarily urban and suburban areas (e.g., Seattle WA and Portland OR), although some urban and suburban sites are underpredicted. Compared to the rural sites, urban and suburban sites have larger FE values. As shown in Figs. 11 and 12, the AIRPACT's PM 2.5 FE has increased with each 30 major update; the differences of FE from AP-3 to AP-5 (in Fig. 12) are positive over most 
This is a non peer-reviewed preprint submitted to EarthArxiv.

sites. This worsening of FE in AP-5 could be attributed to a) the summer of 2015 and 2018 where our model missed large PM2.5 concentrations from wildfires and b) use of the monthly mean chemical boundary condition during February 2, 2018 to October 31, 2018 because the MOZART4 from NCAR was discontinued; otherwise, it is likely that AP-5 may

5 have a similar performance as previous versions, if not better.

\section{Conclusion}

Since May 2001, the Laboratory for Atmospheric Research (LAR) group at Washington State University has been operating the AIRPACT air quality forecast system that predicts immediate future air quality over the PNW region. Currently, we are running the AIRPACT

10 version 5 (AP-5) which forecasts the next 48 hours of high-resolution air quality over the PNW region. Our AIRPACT system comprises three main models: WRF meteorology model, SMOKE emission processing tool, and CMAQ chemical transport model. The CMAQ simulations in AIRPACT use a comprehensive set of emissions that is based on up-to-date emission inventories (i.e., EPA's NEI2014v2 and new state emission inventories) and

15 emission models such as MOVES mobile emission model, MEGAN biogenic emission model, and BlueSky fire emission model.

In this paper, we have evaluated the last 10 years of archived AIRPACT forecast data, from 2009 to 2018, against the EPA's AQS monitoring sites. Our evaluation is limited to the forecast products at the EPA's AQS sites. Over this time period, the AIRPACT system went

20 through two major updates that resulted in system version change: from AP-3 (2007 to 2012) to AP-4 (2013 to 2015) and to AP-5 (2016 to present). The major updates made to the AIRPACT system include: a) incorporating newer model versions for CMAQ, WRF, and SMOKE; b) switching to a different chemical mechanism (e.g., from SAPRC99 to CB05) or to a different sub-model (from MOBILE6 to MOVES; from BEIS to MEGAN); c) using finer

25 horizontal and vertical grids; and d) adapting newer input dataset such as emission inventories and chemical boundary conditions (see the details in Table 1).

AIRPACT $\mathrm{O}_{3}$ forecasting has improved over time. Between AP-3 and AP-4 there are minimal forecast skill differences; however, the update to AP-5 showed notable improvements. AP-5 is improved from AP-3 and AP-4 according to all statistical metrics 
This is a non peer-reviewed preprint submitted to EarthArxiv.

used, excluding $\mathrm{R}^{2}$. In AP-5, the MB and FB are nearly twice as good compared to either preceding version. The switch to CB05 gas chemical mechanism from SAPRC99 lowered the forecasted $\mathrm{O}_{3}$ levels and thus lessened AIRPACT's tendency to overpredict $\mathrm{O}_{3}$, which likely explains the better performance of AP-5. For all versions of AIRPACT, the FB and FE have

5 met the goal benchmark values (i.e., $\mathrm{FB}$ of $\pm 15 \%$ and $\mathrm{FE}$ of $\pm 30 \%$ ) for $\mathrm{O}_{3}$. We find that $\mathrm{O}_{3}$ levels above $30 \mathrm{ppbv}$ were forecasted with higher accuracy than levels below $30 \mathrm{ppbv}$ and $\mathrm{O}_{3}$ forecast performance is generally better in the summer than in the winter, including their diurnal cycles. All versions of AIRPACT struggle at forecasting wintertime $\mathrm{O}_{3}$, with constant overprediction, especially during the night.

Unlike the $\mathrm{O}_{3}$ forecast performance, as AIRPACT has progressed through versions, the $\mathrm{PM}_{2.5}$ forecast performance has worsened from slight overprediction (FB of 4.5\%) in AP-3 to large underprediction (FB of $-32 \%$ ) in AP-5. The poor performance of $\mathrm{PM}_{2.5}$ in AP-5 was likely due to the large underpredictions during spring and summer that are contributed by missing wildfires emissions and using monthly mean chemical boundary condition.

15 However, all versions of AIRPACT meet the criteria benchmark for FB of $\pm 60 \%$.

It is important to understand that our comparisons between different AIRPACT versions are not based on the same period and thus the changes in forecast skills over time are also influenced by the changes in extreme air quality events such as stratospheric ozone intrusion and wildfires. For example, the significant underprediction of $\mathrm{PM}_{2.5}$ in AP-5 is 20 attributed to the summers of 2015 and 2018; where the AP-5 forecast severely underpredicted large $\mathrm{PM}_{2.5}$ concentrations due to wildfires. The PM2.5 underprediction in summer 2018 were largely due to missing smoke from Canadian fires in the chemical boundary conditions: we were using archived monthly mean chemical boundary conditions as MOZART was no longer available and it was before our transition to WACCM. This

25 suggests that a more reliable forecast system to handle extreme air quality events may improve overall forecast accuracy.

This multi-year evaluation provides a unique opportunity to examine how a regional air quality system has evolved over the last 10 years, particularly how the substantial science advances and technical updates applied to the system have affected air quality forecast 
This is a non peer-reviewed preprint submitted to EarthArxiv.

ability. Even though our long-term evaluation reveals that some major updates such as reducing grid size did not improve the forecast skills, the updates made to the system have been based on the latest science, to the best of our knowledge, and thus AIRPACT has evolved into a more advanced air quality forecast system over time. Compared to the substantial

5 efforts went into the AIRPACT updates, our forecast accuracy has improved little, which reflects the challenges in improving forecast skills in the current AIRPACT system that is based on 3-D air quality modeling alone. This finding suggests the need to consider new approaches including data-assimilation, ensemble forecasting, and statistical postprocessing that accounts for systematic model errors and sub-grid processes.

Beardsley, M., Warila, J., Dolce, G., \& Koupal, J. (2009). Air Pollution Emissions from Highway Vehicles: What MOVES Tells Us.

Chen, J., Vaughan, J., Avise, J., O’Neill, S., \& Lamb, B. (2008). Enhancement and evaluation of the AIRPACT ozone and PM 2.5 forecast system for the Pacific Northwest. Journal of Geophysical Research, 113(D14). https://doi.org/10.1029/2007JD009554

Emery, C., Tai, E., \& Yarwood, G. (2001). Enhanced meteorological modeling and performance evaluation for two Texas ozone episodes. Prepared for the Texas natural resource conservation commission, by ENVIRON International Corporation.

Fann, N., Lamson, A. D., Anenberg, S. C., Wesson, K., Risley, D., \& Hubbell, B. J. (2012). Estimating the National Public Health Burden Associated with Exposure to Ambient PM2.5 and Ozone. Risk Analysis, 32(1), 81-95. https://doi.org/10.1111/j.15396924.2011.01630.x

Guenther, A., Karl, T., Harley, P., Wiedinmyer, C., Palmer, P. I., \& Geron, C. (2006). Estimates of global terrestrial isoprene emissions using MEGAN (Model of Emissions of Gases and Aerosols from Nature). Atmospheric Chemistry and Physics, 6(11), 3181-3210.

Herron-Thorpe, F. L., Lamb, B. K., Mount, G. H., \& Vaughan, J. K. (2010). Evaluation of a regional air quality forecast model for tropospheric NO2 columns using the OMI/Aura satellite tropospheric NO2 product. Atmos. Chem. Phys., 16.

Herron-Thorpe, F. L., Mount, G. H., Emmons, L. K., Lamb, B. K., Jaffe, D. A., Wigder, N. L., Chung, S. H., Zhang, R., Woelfle, M. D., \& Vaughan, J. K. (2014). Air quality simulations of wildfires in the Pacific Northwest evaluated with surface and satellite observations during the summers of 2007 and 2008. Atmospheric Chemistry and Physics, 14(22), 12533-12551. https://doi.org/10.5194/acp-14-12533-2014

Hogrefe, C., Isukapalli, S. S., Tang, X., Georgopoulos, P. G., He, S., Zalewsky, E. E., Hao, W., Ku, J.-Y., Key, T., \& Sistla, G. (2011). Impact of biogenic emission uncertainties on the 
This is a non peer-reviewed preprint submitted to EarthArxiv.

simulated response of ozone and fine particulate matter to anthropogenic emission reductions. Journal of the Air \& Waste Management Association (1995), 61(1), 92-108.

Im, U., Bianconi, R., Solazzo, E., Kioutsioukis, I., Badia, A., Balzarini, A., Baró, R., Bellasio, R., Brunner, D., Chemel, C., Curci, G., Flemming, J., Forkel, R., Giordano, L., JiménezGuerrero, P., Hirtl, M., Hodzic, A., Honzak, L., Jorba, O., ... Galmarini, S. (2015). Evaluation of operational on-line-coupled regional air quality models over Europe and North America in the context of AQMEII phase 2. Part I: Ozone. Atmospheric Environment, 115, 404-420. https://doi.org/10.1016/j.atmosenv.2014.09.042

Jaffe, D., Anderson, T., Covert, D., Kotchenruther, R., Trost, B., Danielson, J., Simpson, W., Berntsen, T., Karlsdottir, S., Blake, D., Harris, J., Carmichael, G., \& Uno, I. (1999). Transport of Asian air pollution to North America. Geophysical Research Letters, 26(6), 711-714. https://doi.org/10.1029/1999GL900100

Koupal, J., Cumberworth, M., Michaels, H., Beardsley, M., \& Brzezinski, D. (2003). Design and Implementation of MOVES: EPA's New Generation Mobile Source Emission Model. 15.

Larkin, S. (2016, November 9). Wildland Fire Assessment Tools: SmartFire and BlueSky. http://www.westar.org/Docs/EEworkshop/Larkin.pdf

Luecken, D. J., Phillips, S., Sarwar, G., \& Jang, C. (2008). Effects of using the CB05 vs. SAPRC99 vs. CB4 chemical mechanism on model predictions: Ozone and gas-phase photochemical precursor concentrations. Atmospheric Environment, 42(23), 58055820. https://doi.org/10.1016/j.atmosenv.2007.08.056

Mahmud, A. (2005). EVALUATION OF THE AIRPACT2 AIR QUALITY FORECAST SYSTEM FOR THE PACIFIC NORTHWEST [Washington State University]. https://research.libraries.wsu.edu/xmlui/bitstream/handle/2376/402/a_mahmud _091605.pdf?sequence $=1$

25 Mass, C. F., Albright, M., Ovens, D., Steed, R., Maciver, M., Grimit, E., Eckel, T., Lamb, B., Vaughan, J., Westrick, K., Storck, P., Colman, B., Hill, C., Maykut, N., Gilroy, M., Ferguson, S. A., Yetter, J., Sierchio, J. M., Bowman, C., ... Brown, W. (2003). Regional Environmental Prediction Over the Pacific Northwest. Bulletin of the American Meteorological Society, 84(10), 1353-1366. https://doi.org/10.1175/BAMS-84-101353

Neidell, M. (2004). Air pollution, health, and socio-economic status: the effect of outdoor air quality on childhood asthma. Journal of Health Economics, 23(6), 1209-1236. https://doi.org/10.1016/j.jhealeco.2004.05.002

Thunis, P., Georgieva, E., \& Galmarini, S. (2011). A procedure for air quality models benchmarking, Version 2.

US EPA. (2015a, May 29). The Clean Air Act - Highlights of the 1990 Amendments [Overviews and Factsheets]. US EPA. https://www.epa.gov/clean-air-act-overview/clean-airact-highlights-1990-amendments

US EPA, O. (2015b, June 2). National Emissions Inventory (NEI) [Policies and Guidance]. US EPA. $\quad$ https://www.epa.gov/air-emissions-inventories/national-emissionsinventory-nei 
This is a non peer-reviewed preprint submitted to EarthArxiv.

US EPA, O. (2016, June 1). Description and History of the MOBILE Highway Vehicle Emission Factor Model [Overviews and Factsheets]. US EPA. https://www.epa.gov/moves/description-and-history-mobile-highway-vehicleemission-factor-model

5 Vaughan, J., Lamb, B., Frei, C., Wilson, R., Bowman, C., Figueroa-Kaminsky, C., Otterson, S., Boyer, M., Mass, C., Albright, M., Koenig, J., Collingwood, A., Gilroy, M., \& Maykut, N. (2004). A Numerical Daily Air Quality Forecast System for The Pacific Northwest. Bulletin of the American Meteorological Society, 85(4), 549-562. https://doi.org/10.1175/BAMS-85-4-549

10 Vukovich, J. M., \& Pierce, T. (2002). Implementation of BEIS3 within the SMOKE modeling framework. Proceedings of the 11th International Emissions Inventory Conference, Atlanta, Georgia, 15-18.

WHO. (2016). WHO / Ambient air pollution: A global assessment of exposure and burden of disease. WHO. http://www.who.int/phe/publications/air-pollution-global-

15 assessment/en/

\section{Acknowledgements}

This work has been supported by the NW-AIRQUEST consortium of air quality agencies in 20 the Pacific Northwest. 
This is a non peer-reviewed preprint submitted to EarthArxiv.

\section{Decadal Evaluation of the AIRPACT Regional Air Quality Forecast System in the Pacific Northwest from 2009-2018}

Jordan A. Munson ${ }^{1 \#, ~ J o e ~ V a u g h a n ~}{ }^{1}$, Brian Lamb ${ }^{1}$, and Yunha Lee ${ }^{1 *}$

${ }^{1}$ Laboratory for Atmospheric Research Civil and Environmental Engineering, Washington State University, Pullman, 99163, United States

\#now at Wisconsin Department of Natural Resources, Madison, WI 53707-7921

*now at Center for Advanced Systems Understanding, Helmholtz-Zentrum Dresden-

Rossendorf, Dresden, Germany

Correspondence to: Yunha Lee (y.lee@hzdr.de)

Figures and Tables are presented in this document. 
This is a non peer-reviewed preprint submitted to EarthArxiv.

Table 1. Description of the AIRPACT systems used from 2009 to 2018

\begin{tabular}{|c|c|c|c|}
\hline Category & $\begin{array}{l}\text { AIRPACT-3 } \\
\text { (AP-3) }\end{array}$ & $\begin{array}{l}\text { AIRPACT-4 } \\
\text { (AP-4) }\end{array}$ & $\begin{array}{l}\text { AIRPACT-5 } \\
\text { (AP-5) }\end{array}$ \\
\hline Duration & 2007- Dec 2012 & Jan 2013 - Dec 2015 & Jan 2016 - Current \\
\hline Horizontal grid size & $12-\mathrm{km}$ & $4-\mathrm{km}$ & $4-\mathrm{km}$ \\
\hline Number of vertical layers & 21 & 21 & 37 \\
\hline Meteorology model & $\begin{array}{l}\text { MM5 3.7.3 (before } \\
\text { April 2008), } \\
\text { WRF v3.1.1 }\end{array}$ & WRF v3.4.1, v3.5 & WRF v3.6.1, v3.7.1 \\
\hline $\mathrm{MCIP}$ & v3.3 & v3.6 & v3.6 \\
\hline SMOKE emission tool & v2.1 & v2.7, v3.5 & v3.5.1 \\
\hline CMAQ version & v4.6 & v4.7.1 & v5.0.2 \\
\hline $\begin{array}{l}\text { Mass Adjustment } \\
\text { (CMAQ) }\end{array}$ & denrate & yamo & yamo \\
\hline Gas-Phase Mechanism & SAPRC99 & SAPRC99 & CB05 \\
\hline $\begin{array}{l}\text { Non-mobile } \\
\text { Anthropogenic } \\
\text { Emissions }\end{array}$ & $\begin{array}{l}2005 \text { from Ecology, } \\
\text { IDEQ, ODEQ }\end{array}$ & $\begin{array}{c}2007-2008 \text { from } \\
\text { Ecology, IDEQ, ODEQ }\end{array}$ & NEI 2014v2 \\
\hline Mobile Emissions & MOBILE6 & MOBILE6, MOVES & MOVES 2010b \\
\hline Fire Emissions & BlueSky & $\begin{array}{l}\text { SMARTFirev1/BlueSky } \\
\text { SMARTFire v2, } \\
\text { BlueSky 3.5.1 (2014 } \\
\text { and later) }\end{array}$ & $\begin{array}{c}\text { SMARTFire v2, } \\
\text { BlueSky 3.5.1 }\end{array}$ \\
\hline Biogenic Emissions & BEIS-3 & MEGAN v2.0.4 & MEGAN v2.1 \\
\hline Boundary Conditions & $\begin{array}{l}\text { MOPITT CO Assimilated } \\
\text { MOZART-4 Forecast } \\
\text { from LOUISA Emmons } \\
\text { of NCAR }\end{array}$ & $\begin{array}{c}\text { MOPITT CO } \\
\text { Assimilated MOZART- } \\
4 \text { Forecast from } \\
\text { LOUISA Emmons of } \\
\text { NCAR }\end{array}$ & $\begin{array}{l}\text { MOZART4 ceased Jan } \\
\text { 2018, since then } \\
\text { Monthly averaged } \\
\text { from } 2014\end{array}$ \\
\hline
\end{tabular}


This is a non peer-reviewed preprint submitted to EarthArxiv.

Table 2. Statistical results of daily maximum 8-hour average (DM8A) ozone performance at the EPA AQS sites in the AIRPACT domain that from 2009 to 2018. Values shown are for the entire duration of the corresponding AIRPACT version.

\begin{tabular}{ccccccccccccc}
\hline \multicolumn{1}{c}{ Forecast } & \multicolumn{1}{c}{ Observation } & & & & & & & \\
$\begin{array}{c}\text { AIRPACT } \\
\text { Version }\end{array}$ & $\begin{array}{c}\text { Mean } \\
{[\mathrm{ppb}]}\end{array}$ & $\begin{array}{c}\text { 98th } \\
{[\mathrm{ppb}]}\end{array}$ & $\begin{array}{c}\text { Mean } \\
{[\mathrm{ppb}]}\end{array}$ & $\begin{array}{c}\text { 98th } \\
{[\mathrm{ppb}]}\end{array}$ & $\begin{array}{c}\mathrm{Mppb}] \\
{[\mathrm{ppb}]}\end{array}$ & $\begin{array}{c}\mathrm{FB} \\
{[\%]}\end{array}$ & $\begin{array}{c}\mathrm{FE} \\
{[\%]}\end{array}$ & $\begin{array}{c}\text { NMB } \\
{[\%]}\end{array}$ & $\begin{array}{c}\text { NME } \\
{[\%]}\end{array}$ & $\begin{array}{c}\text { RMSE } \\
{[\mathrm{ppb}]}\end{array}$ & $\begin{array}{c}\text { R2 } \\
{[-]}\end{array}$ \\
\hline AP-3 & 40 & 57 & 36 & 52 & 4.7 & 5.7 & 14 & 17 & 13 & 16 & 7.1 & 0.67 \\
AP-4 & 42 & 63 & 37 & 55 & 5.0 & 6.0 & 14 & 17 & 14 & 16 & 7.7 & 0.68 \\
AP-5 & 40 & 56 & 37 & 56 & 2.6 & 4.9 & 8.1 & 14 & 7.0 & 13 & 6.8 & 0.54 \\
Overall & 41 & 59 & 36 & 55 & 4.2 & 5.6 & 12 & 16 & 11 & 15 & 7.2 & 0.62 \\
\hline
\end{tabular}


This is a non peer-reviewed preprint submitted to EarthArxiv.

Table 3. Same as Table 2 but for daily $\mathrm{PM}_{2.5}$ concentrations

\begin{tabular}{|c|c|c|c|c|c|c|c|c|c|c|c|c|}
\hline \multirow[b]{2}{*}{$\begin{array}{l}\text { AIRPACT } \\
\text { Version }\end{array}$} & \multicolumn{2}{|c|}{ Forecast } & \multicolumn{2}{|c|}{ Observation } & \multirow[b]{2}{*}{$\begin{array}{c}\mathrm{MB} \\
{\left[\mu \mathrm{g} \mathrm{m}^{-3}\right]}\end{array}$} & \multirow[b]{2}{*}{$\begin{array}{c}\mathrm{ME} \\
{\left[\mu \mathrm{g} \mathrm{m}^{-3}\right]}\end{array}$} & \multirow[b]{2}{*}{$\begin{array}{l}\text { FB } \\
{[\%]}\end{array}$} & \multirow[b]{2}{*}{$\begin{array}{l}\mathrm{FE} \\
{[\%]}\end{array}$} & \multirow[b]{2}{*}{$\begin{array}{c}\text { NMB } \\
{[\%]}\end{array}$} & \multirow[b]{2}{*}{$\begin{array}{l}\text { NME } \\
{[\%]}\end{array}$} & \multirow[b]{2}{*}{$\begin{array}{c}\text { RMSE } \\
{\left[\mu \mathrm{g} \mathrm{m}^{-3}\right]}\end{array}$} & \multirow[b]{2}{*}{$\begin{array}{l}\text { R2 } \\
{[-]}\end{array}$} \\
\hline & $\begin{array}{c}\text { Mean } \\
{\left[\mu \mathrm{g} \mathrm{m}^{-3}\right]}\end{array}$ & $\begin{array}{c}\text { 98th } \\
{\left[\mu \mathrm{g} \mathrm{m}^{-3}\right]}\end{array}$ & $\begin{array}{c}\text { Mean } \\
{\left[\mu \mathrm{g} \mathrm{m}^{-3}\right]}\end{array}$ & $\begin{array}{c}\text { 98th } \\
{\left[\mu \mathrm{g} \mathrm{m}^{-3}\right]}\end{array}$ & & & & & & & & \\
\hline AP-3 & 6.8 & 19.1 & 7.0 & 16.8 & -0.2 & 1.9 & -4.5 & 26 & -2.5 & 27 & 2.6 & 0.59 \\
\hline AP-4 & 6.5 & 18.0 & 7.7 & 20.6 & -1.3 & 2.1 & -18 & 28 & -16 & 27 & 3.7 & 0.48 \\
\hline AP-5 & 6.0 & 18.4 & 7.8 & 30.4 & -1.8 & 2.7 & -32 & 38 & -23 & 34 & 5.8 & 0.55 \\
\hline Overall & 6.5 & 18.3 & 7.5 & 20.6 & -1.0 & 2.2 & -17 & 31 & -13 & 29 & 4.2 & 0.53 \\
\hline
\end{tabular}


This is a non peer-reviewed preprint submitted to EarthArxiv.

Table 4. Summary of forecast verification metrics for ozone and $\mathrm{PM}_{2.5}$ air quality index (AQI). FAR stands for False Alarm Ratio and POD for Probability of Detection. AQI rows are based on the full spectrum of AQI values, whereas the unit value rows are based on a single value ceiling.

\begin{tabular}{|c|c|c|c|c|c|}
\hline & Species & Metric & AP-3 & AP-4 & AP-5 \\
\hline \multirow{4}{*}{$0^{m}$} & \multirow{2}{*}{$A Q I$} & FAR & 0.035 & 0.10 & 0.02 \\
\hline & & POD & 1.0 & 0.99 & 0.98 \\
\hline & \multirow{2}{*}{$>27$ ppb } & FAR & 0.91 & 0.80 & 0.83 \\
\hline & & POD & 0.96 & 0.89 & 0.75 \\
\hline \multirow{4}{*}{ 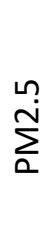 } & \multirow{2}{*}{ AQI } & FAR & 0.043 & 0.034 & 0.024 \\
\hline & & POD & 0.96 & 0.93 & 0.93 \\
\hline & \multirow{2}{*}{$>6 \mu \mathrm{g} \mathrm{m}^{-3}$} & FAR & 0.21 & 0.076 & 0.054 \\
\hline & & POD & 0.76 & 0.72 & 0.80 \\
\hline
\end{tabular}

The FAR has an ideal value of zero, and the POD has an ideal value of one. The FAR describes how often the forecast predicted a higher AQI than observations. The POD describes how often the forecast predicted a lower AQI than observation. 
This is a non peer-reviewed preprint submitted to EarthArxiv.

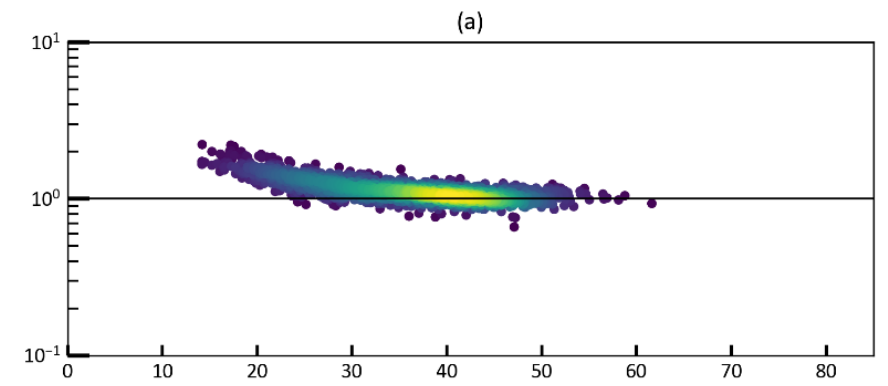

(b)
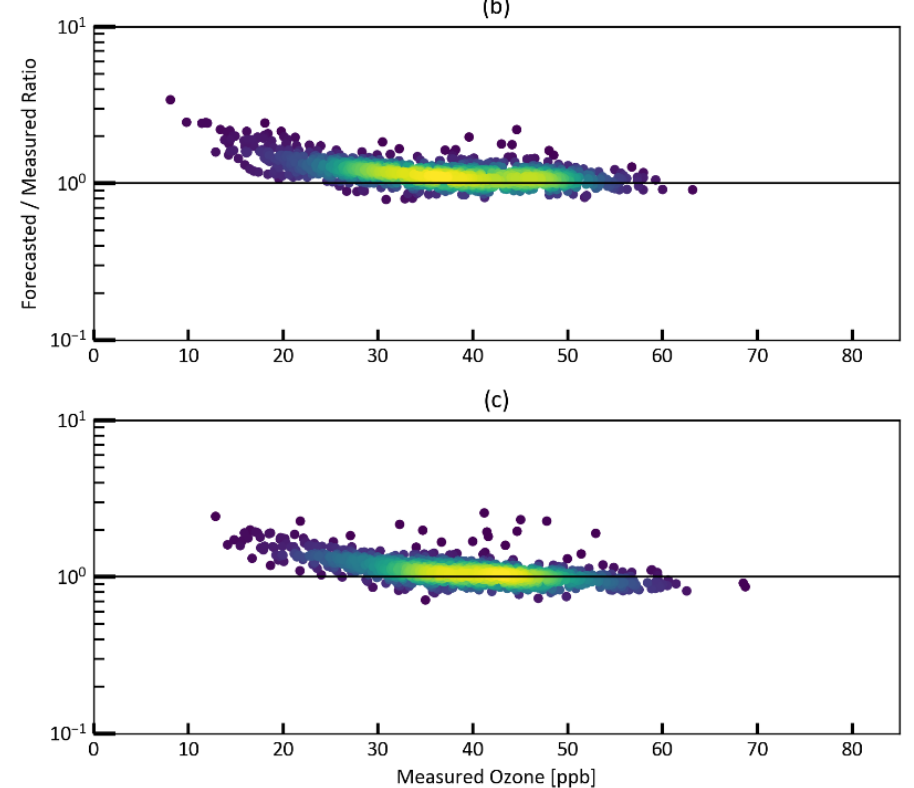

Figure1. Ratio of forecasted to measured DM8A ozone against measured values for AP-3 (a), AP-4 (b), and AP-5 (c). 
This is a non peer-reviewed preprint submitted to EarthArxiv.

(a) AP-3

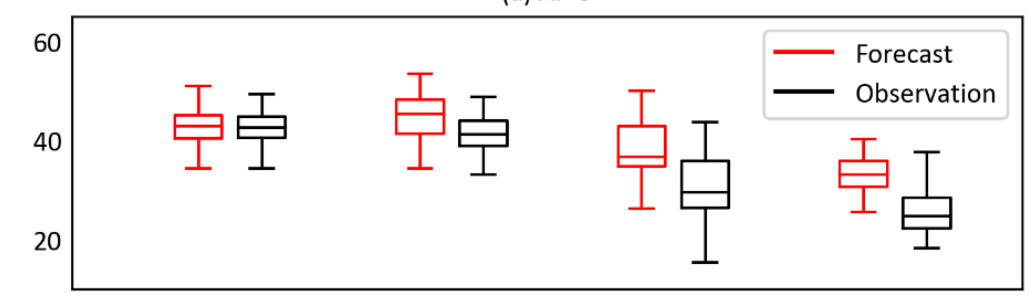

(b) AP-4

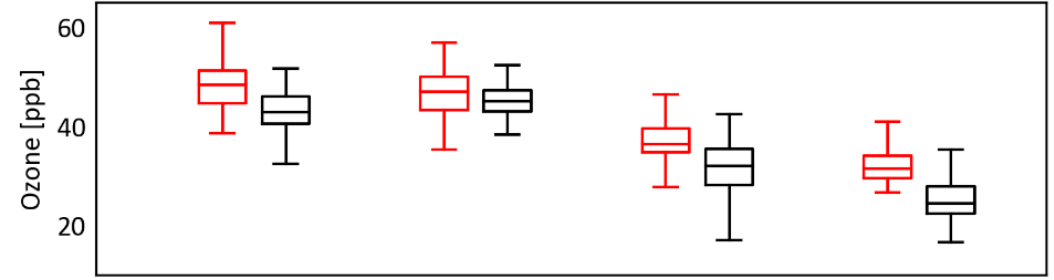

(c) AP-5

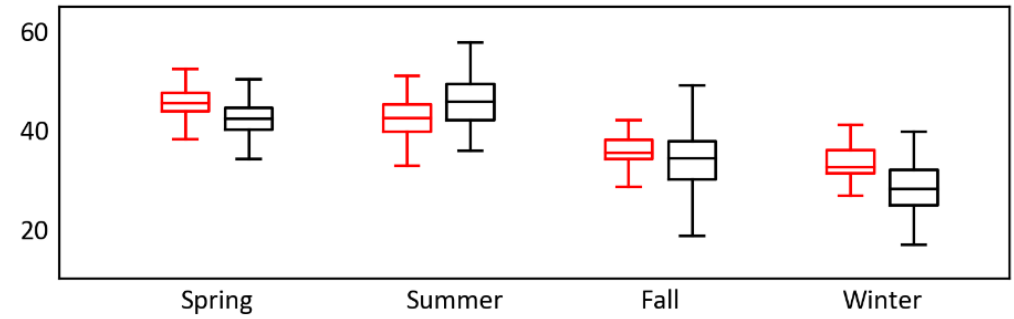

Figure 2. Boxplots of the AIRPACT MD8A ozone during AP-3 (a), AP-4 (b), and AP-5 (c). Within the plots the top whisker, top line, middle line, bottom line, and bottom whisker represent the $4^{\text {th }}$ quartile, $3^{\text {rd }}$ quartile, median, $2^{\text {nd }}$ quartile, and $1^{\text {st }}$ quartile respectively. 
This is a non peer-reviewed preprint submitted to EarthArxiv.

(a) AP-3

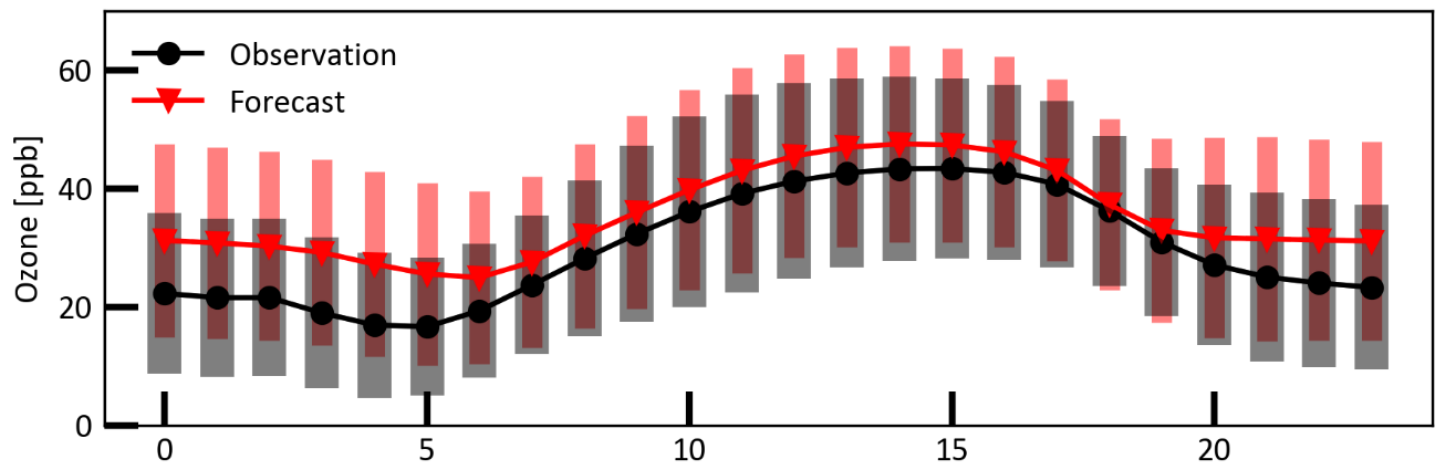

(b) AP-4

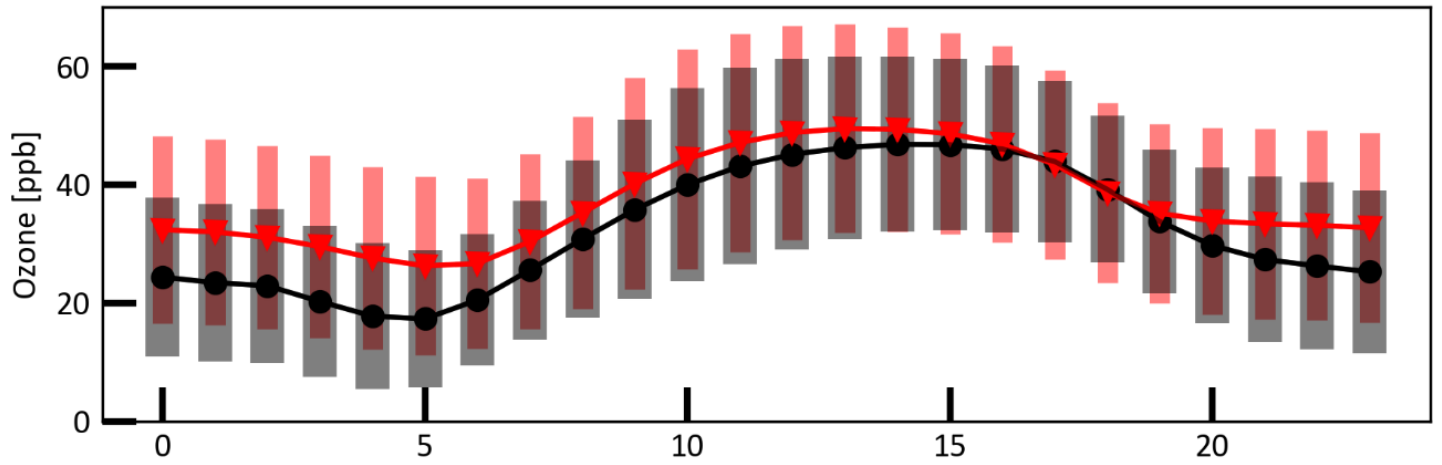

(c) AP-5

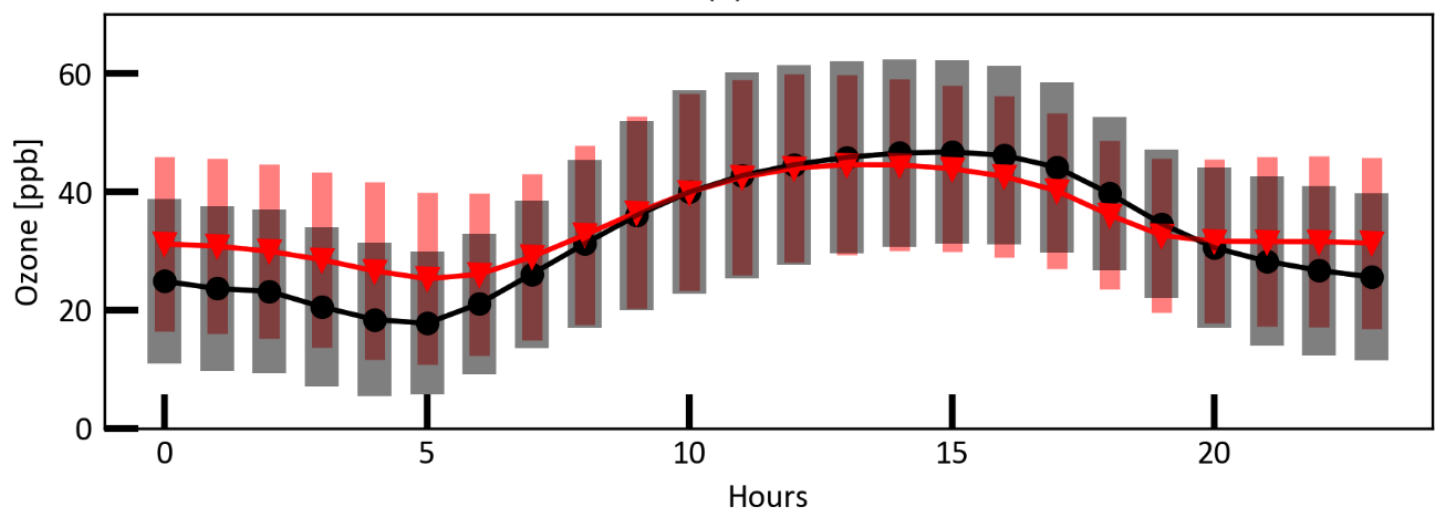

Figure 3. Observed and simulated summertime diurnal ozone concentrations at 26 common sites for AP-3 (a), AP-4 (b), and AP-5 (c). The lines represent average concentration while the shaded boxes are standard deviation. 
This is a non peer-reviewed preprint submitted to EarthArxiv.

(a) AP-3

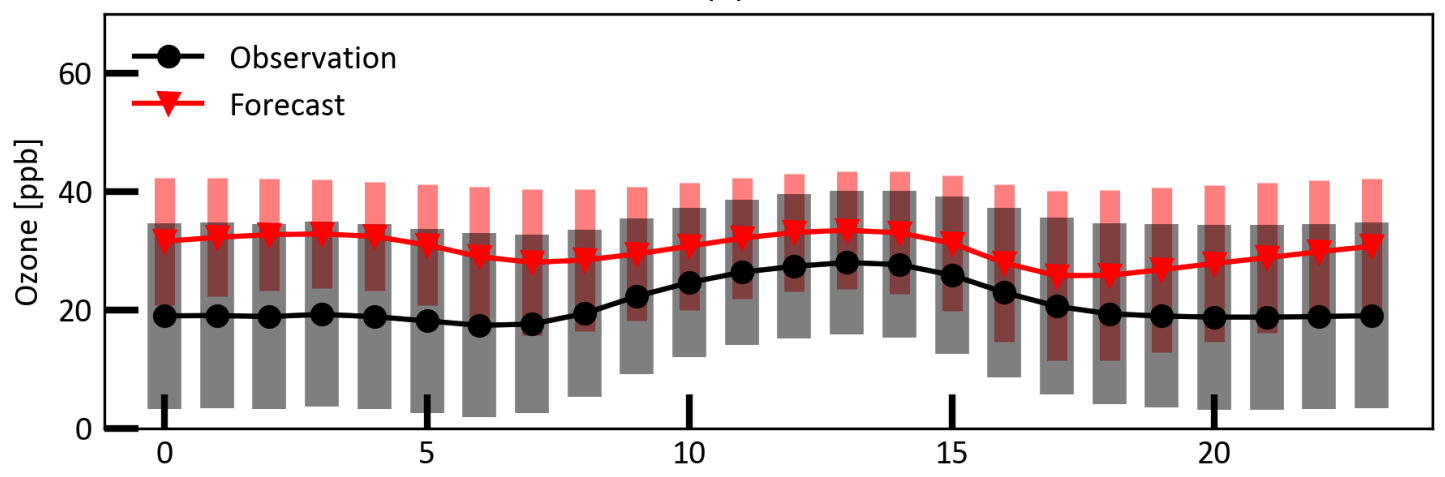

(b) AP-4

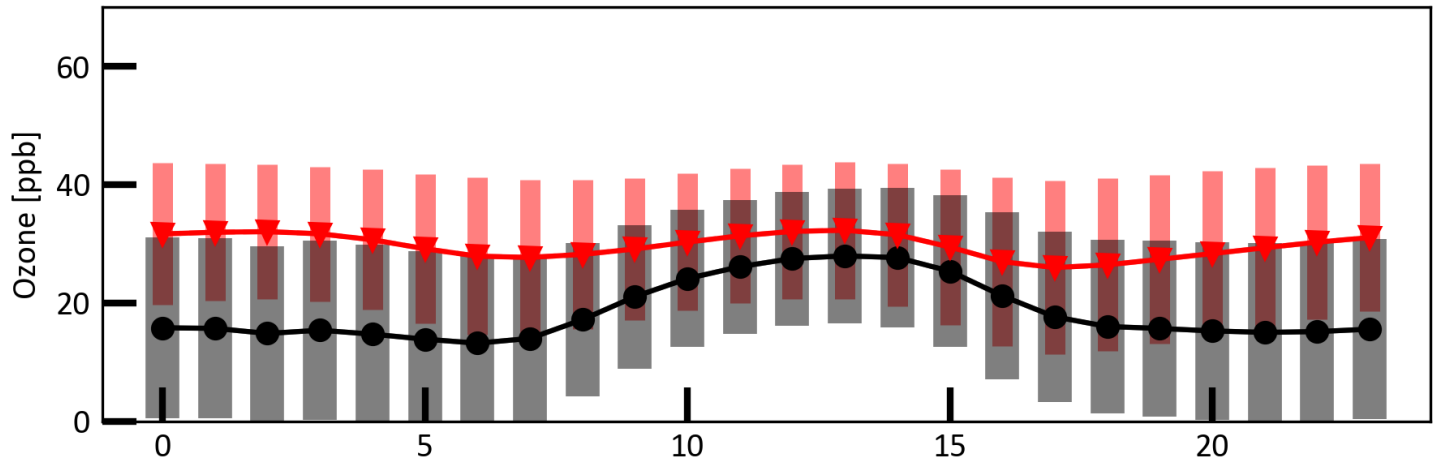

(c) AP-5

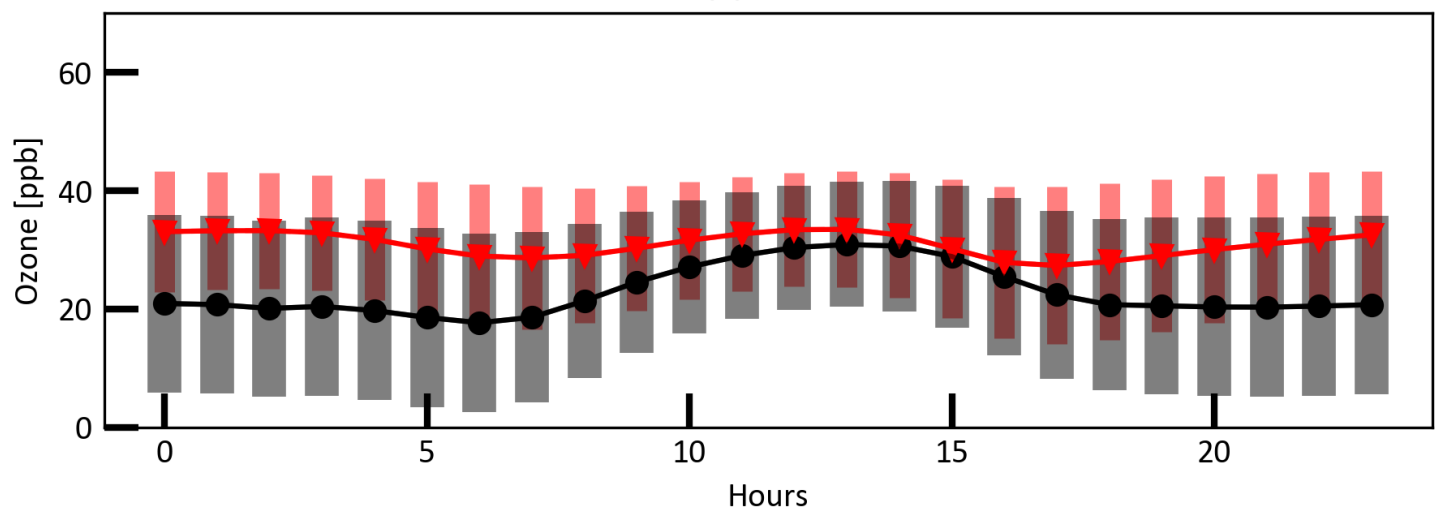

Figure 4. Observed and simulated wintertime diurnal ozone concentrations at 26 common sites for AP-3 (a), AP-4 (b), and AP-5 (c). The lines represent average concentration while the shaded boxes are standard deviation. 
(a)
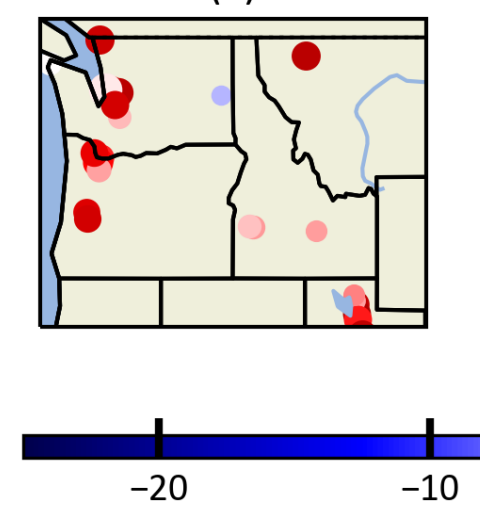

(b)

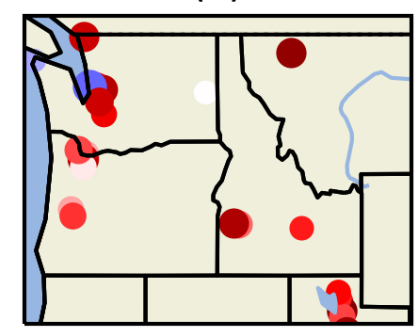

FB [\%] (c)
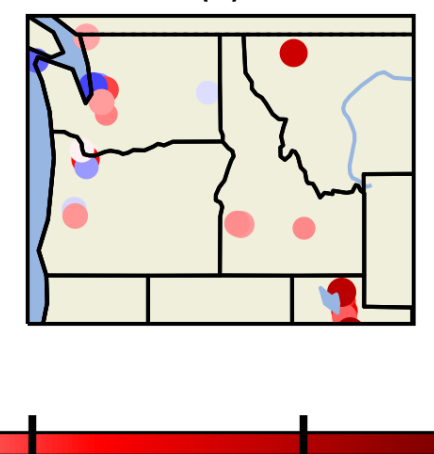

10

Figure 5. Spatial distribution of DM8A ozone fractional bias (FB) and fractional error (FE) of AP-3 (a), AP-4 (b), and AP-5 (c). At each monitor site, FB is represented by color bar and $\mathrm{FE}$ is represented by circle size. 
This is a non peer-reviewed preprint submitted to EarthArxiv.

(a) Fractional Bias

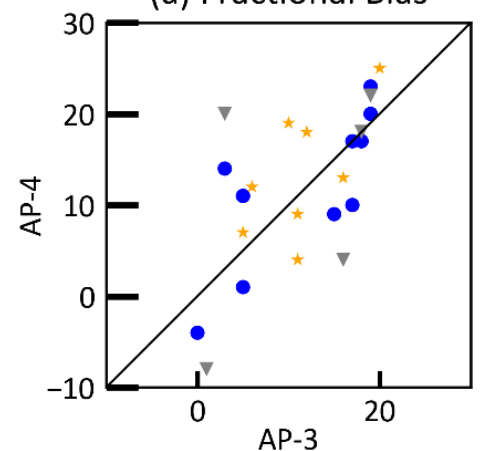

(d) Fractional Error

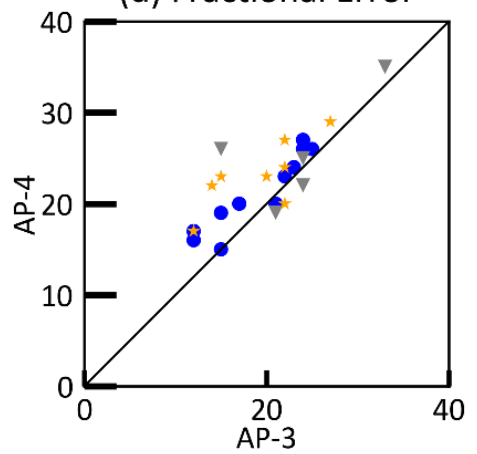

(b) Fractional Bias

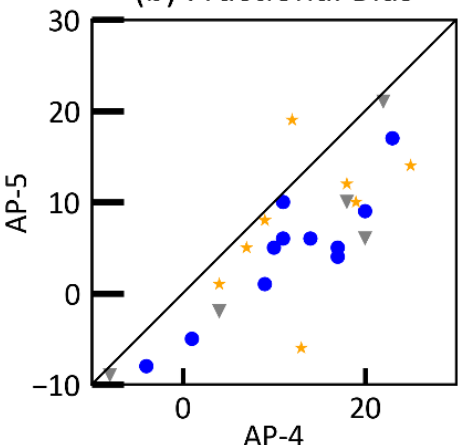

(e) Fractional Error

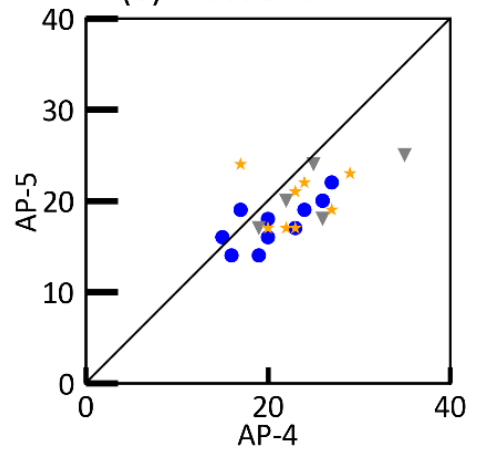

(c) Fractional Bias

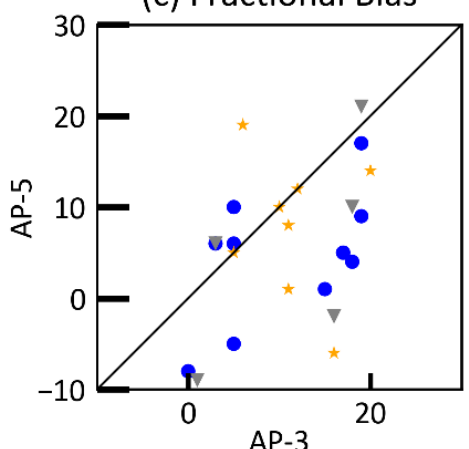

(f) Fractional Error

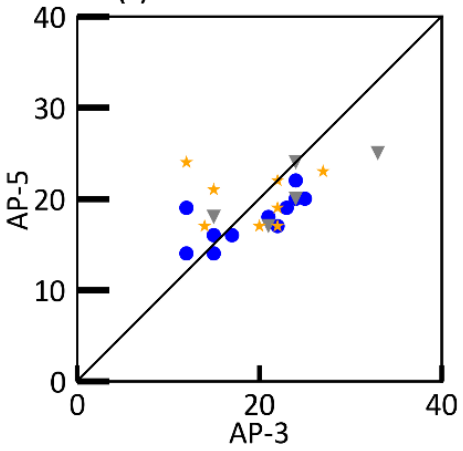

- Rural $\nabla$ Urban * Suburban

Figure 6. DM8A ozone scatter plots of fractional bias (FB) and fractional error (FE) between two AIRPACT versions at monitor sites. Blue, orange, and grey circles represent rural, suburban and urban sites, in respectively.

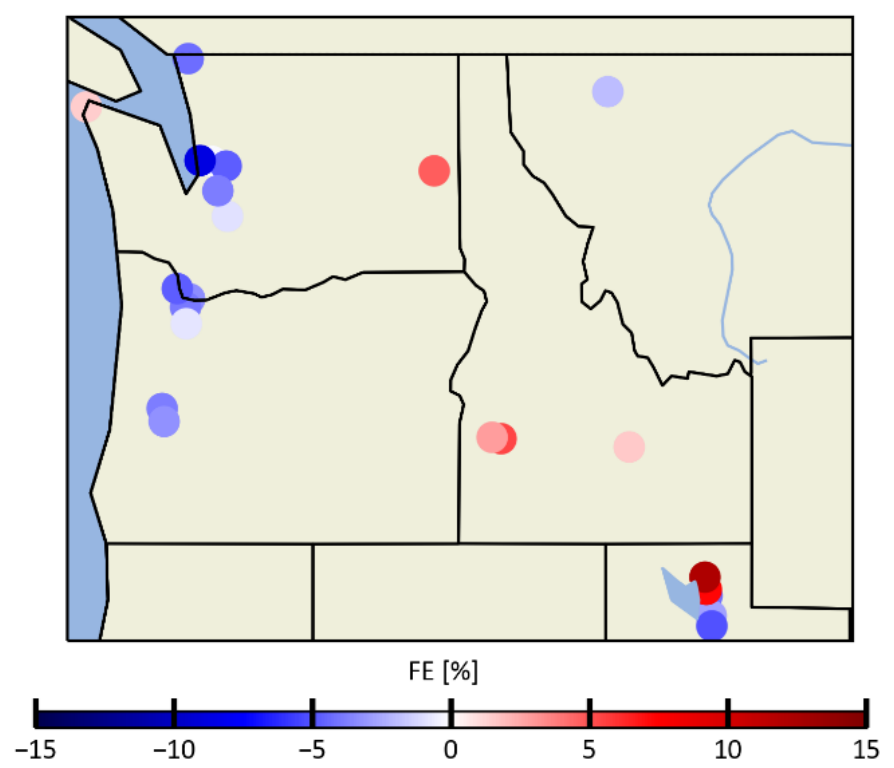


This is a non peer-reviewed preprint submitted to EarthArxiv.

Figure 7. Spatial distribution of DM8A Ozone fractional bias (FE) difference between AP-5 and AP-3 At each monitor site, FE is represented by color bar.

(a)

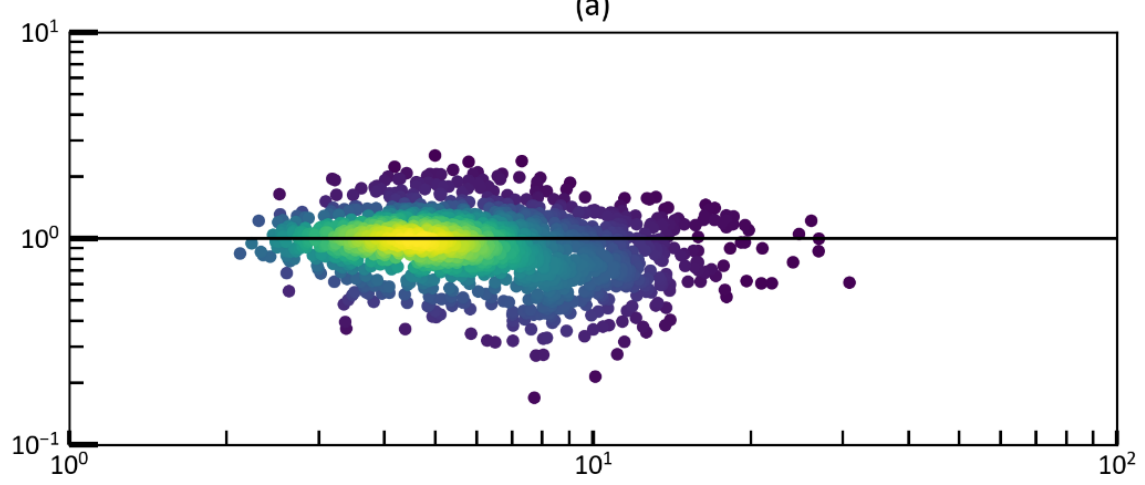

(b)

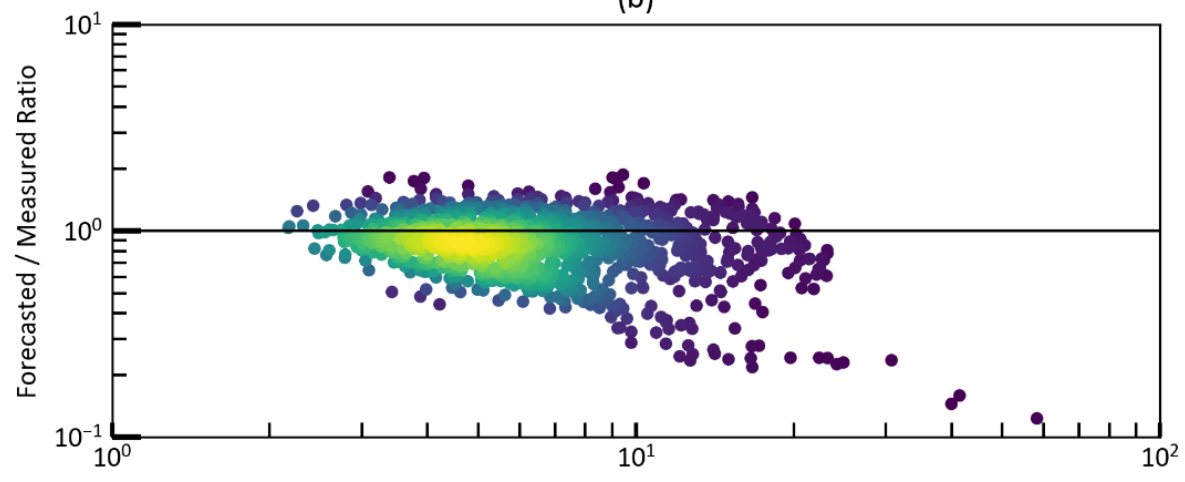

(c)

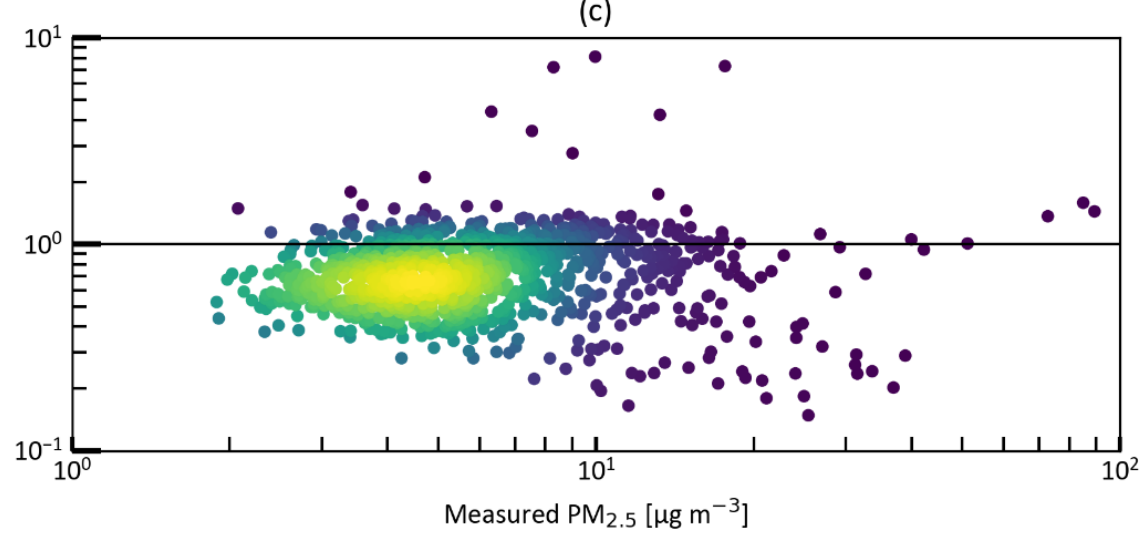

Figure 8. Ratio of forecasted to measured daily $\mathrm{PM}_{2.5}$ against measured values for AP-3 (a), AP-4 (b), and AP-5 (c). 
This is a non peer-reviewed preprint submitted to EarthArxiv.

(a) AP-3

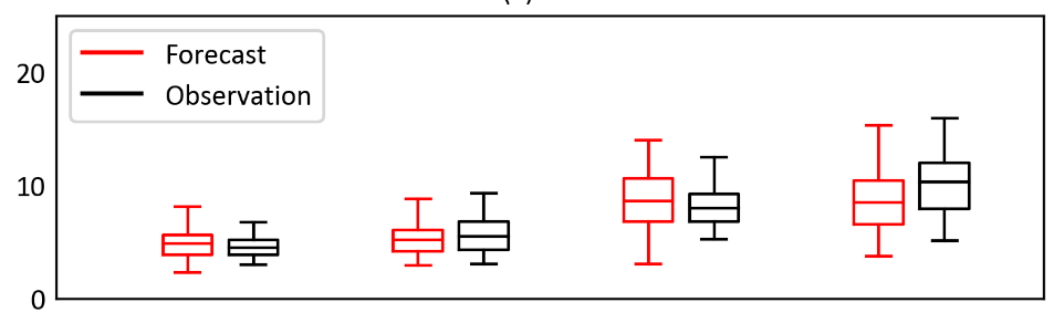

(b) AP-4

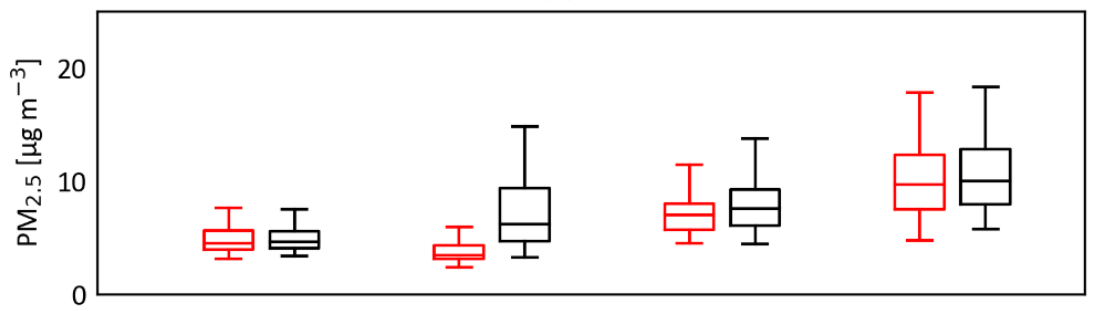

(c) AP-5

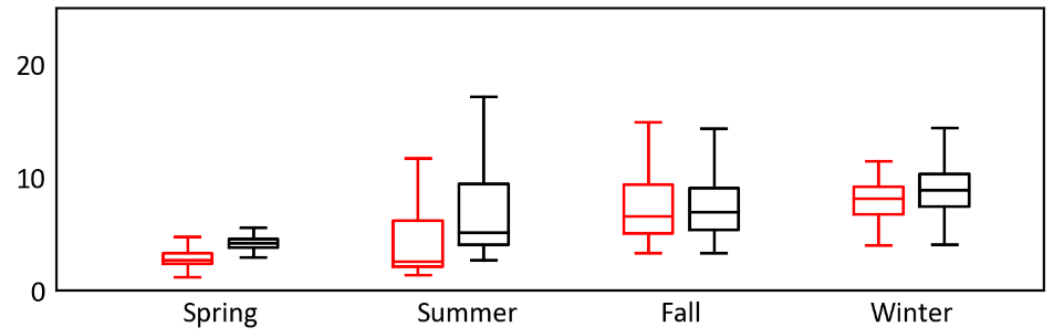

Figure 9. Boxplots of the AIRPACT daily $\mathrm{PM}_{2.5}$ average during AP-3 (a), AP-4 (b), and AP-5 (c). Within the plots the top whisker, top line, middle line, bottom line, and bottom whisker represent the $4^{\text {th }}$ quartile, $3^{\text {rd }}$ quartile, median, $2^{\text {nd }}$ quartile, and $1^{\text {st }}$ quartile respectively.

(a)

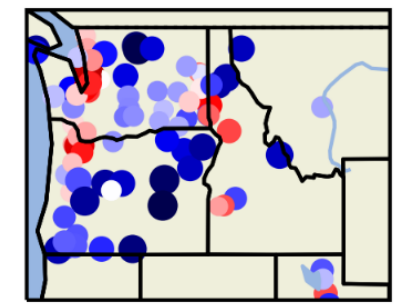

(c)

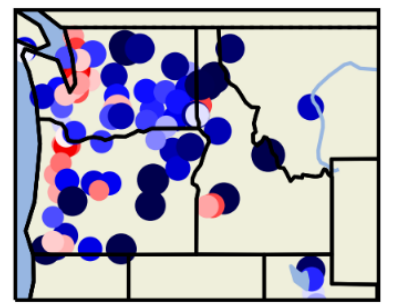

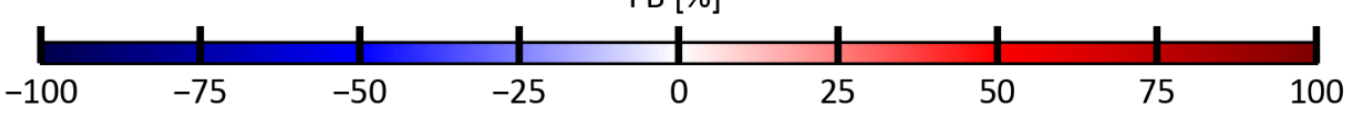

(b)

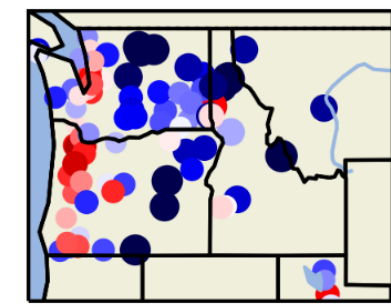

$\mathrm{FB}[\%]$

- 50

- 75

100

- 125

Figure 10. Spatial distribution of daily PM2.5 fractional bias (FB) and fractional error (FE) of AP-3 (a), AP-4 (b), and AP-5 (c). At each monitor site, FB is represented by color bar and $\mathrm{FE}$ is represented by circle size. 
This is a non peer-reviewed preprint submitted to EarthArxiv.

(a) Fractional Bias

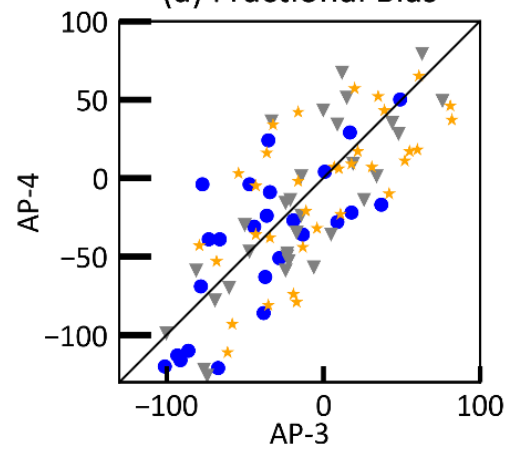

(d) Fractional Error

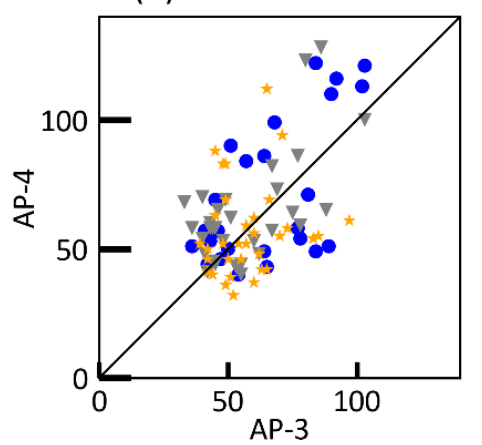

(b) Fractional Bias

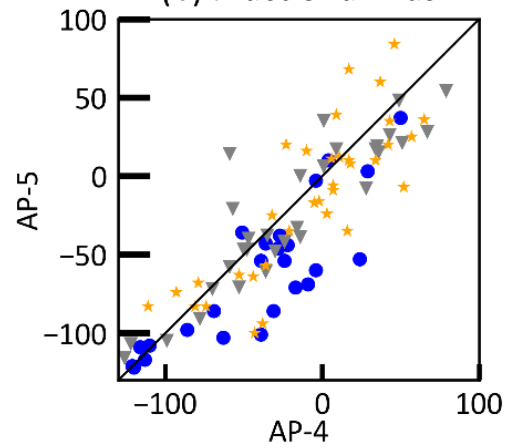

(e) Fractional Error

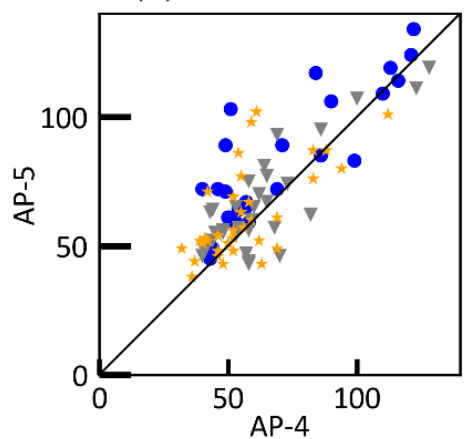

(c) Fractional Bias

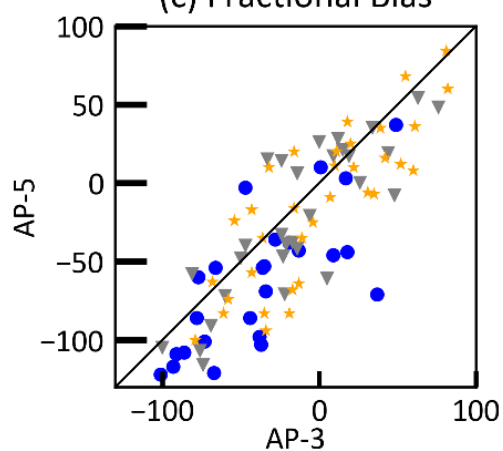

(f) Fractional Error

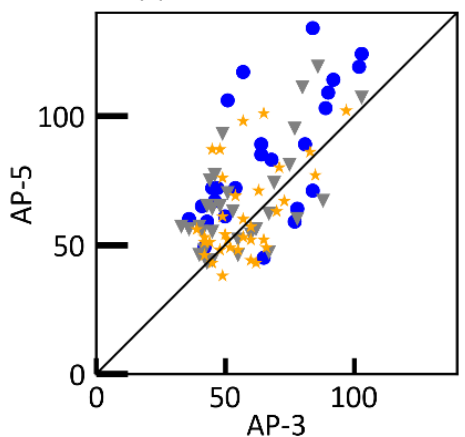

- Rural $\vee$ Urban * Suburban

Figure 11. $\mathrm{PM}_{2.5}$ scatter plots of fractional bias (FB) and fractional error (FE) between two AIRPACT versions at monitor sites. Blue, orange, and grey circles represent rural, suburban and urban sites, in respectively.

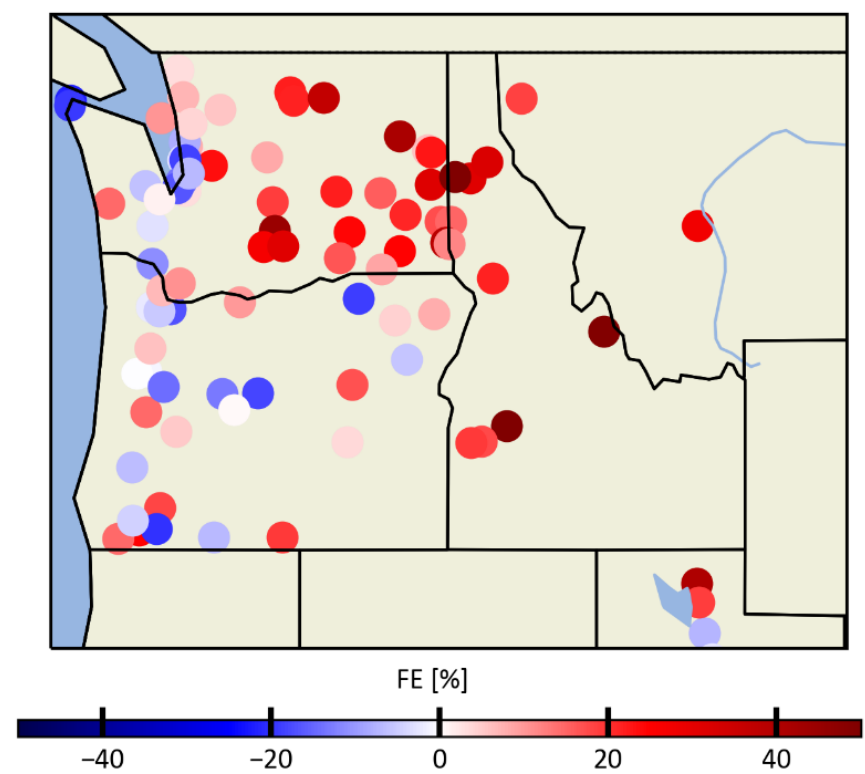


This is a non peer-reviewed preprint submitted to EarthArxiv.

Figure 12. Spatial distribution of daily $\mathrm{PM}_{2.5}$ fractional bias (FE) difference between AP-5 and AP-3 at each monitor site, FE is represented by color bar. 
This is a non peer-reviewed preprint submitted to EarthArxiv.

Supplementary materials

\section{Decadal Evaluation of the AIRPACT Regional Air Quality Forecast System in the Pacific Northwest from 2009-2018}

Jordan A. Munson ${ }^{1 \#, ~ J o e ~ V a u g h a n ~}{ }^{1}$, Brian Lamb ${ }^{1}$, and Yunha Lee ${ }^{1 *}$

${ }^{1}$ Laboratory for Atmospheric Research Civil and Environmental Engineering, Washington State University, Pullman, 99163, United States

\#now at Wisconsin Department of Natural Resources, Madison, WI 53707-7921

*now at Center for Advanced Systems Understanding, Helmholtz-Zentrum DresdenRossendorf, Dresden, Germany

Correspondence to: Yunha Lee (y.lee@hzdr.de)

AIRPACT forecasting system has been using the Weather Research and Forecasting (WRF) model to simulate meteorology fields which are inputs for CMAQ. WRF is operated by University of Washington and their outputs are transferred to Washington State University to perform AIRPACT forecasts. The WRF model used in AIRPACT has been updating multiple times during 2009-2018, from WRF v3.1.1 to WRF v3.7.1 Compared to WRF v3.1.1 used in AP-3, WRF v3.4.1 used in AP-4 had a newer YSU PBL scheme, which improved nighttime eddy diffusivity and thus surface temperature predictions (Hu, Klein, \& Xue, 2013). WRF v3.4.1 was replaced with WRF v3.5 during AP-4, but these WRF updates made little change in AIRPACT forecast: it is based on the previous work done in our group, but not published. With the update to WRF v3.6.1 used for the early period of AP-5 (from WRF v3.5 in AP-4), the land surface model component of WRF was changed from the Noah Land Surface Model (NOAH) to the NOAH Multi Physics (NOAH MP) model. NOAH MP handles vegetation differently, with separate top and bottom canopies, and has a more in depth hydrologic component, allowing a more accurate representation of the surface when covered in snow (Niu et al., 2011).

Due to the long-term storage issues, we lost some archived meteorology forecasts, which hinder the portion of the meteorology analysis. We still evaluated WRF performances against the observation at EPA AQS sites, which are compared to two sets of benchmark values: simple case benchmark from Emery et al. (2001) and complex case benchmark from McNally et al. (2009) (shown in S-Table 1). First of all, specific humidity and wind direction are well within the simple case benchmark values for all three AIRPACT versions. Wind speed performance are slightly worse than the simple MB benchmark values (i.e., $-0.5 \mathrm{~m} \mathrm{~s}^{-}$ 
This is a non peer-reviewed preprint submitted to EarthArxiv.

1) but is well within the RMSE benchmark (i.e., $\pm 2 \mathrm{~m} \mathrm{~s}^{-1}$ ). Temperature is shown to be the least satisfactory, as it even falls out of the complex case MB benchmark value (i.e., $\pm 2.0 \mathrm{~K}$ ) before the AP-5 period.

Updates made into the WRF model does not necessarily improve meteorology forecasts in all aspect. Based on the ME/RMSE values, wind speed and wind direction are improved approximately by $10-30 \%$ from AP-3 to AP-4 and by $0-15 \%$ from AP-4 to AP-5. Temperature and humidity are worsened approximately by $40-130 \%$ from AP-3 to AP-4, although it is improved by $30-60 \%$ from AP-4 to AP-5. The poor performance in temperature and humidity in AP-4, compared to AP-3, is rather unexpected as the grid resolution was changed from $12 \mathrm{~km} \times 12 \mathrm{~km}$ to $4 \mathrm{~km} \times 4 \mathrm{~km}$ along with other updates.

S-Table 1. Statistical results of WRF performance at EPA AQS sites in the AIRPACT domain from 2009 to 2018 that compared to the benchmark values obtained from Emery et al. (2001) and McNally et al. (2009). For the model values falling out of the benchmark, it is marked as red color.

\begin{tabular}{|c|c|c|c|c|c|c|}
\hline Parameter & & $\begin{array}{l}\text { Benchmark } \\
\text { (simple) }\end{array}$ & $\begin{array}{l}\text { Benchmark } \\
\text { (complex) }\end{array}$ & AP-3 & AP-4 & AP-5 \\
\hline \multirow{2}{*}{$\begin{array}{c}\text { Temperature } \\
\text { (Temp) }[\mathrm{K}]\end{array}$} & $\mathrm{MB}$ & $\leq \pm 0.5$ & $\leq \pm 2.0$ & -2.1 & -3.1 & -1.2 \\
\hline & $\mathrm{ME}$ & $\leq \pm 2$ & $\leq \pm 3.5$ & 2.3 & 3.3 & 1.2 \\
\hline \multirow{2}{*}{$\begin{array}{l}\text { Wind speed (WS) } \\
{\left[\mathrm{m} \mathrm{s}^{-1}\right]}\end{array}$} & $\mathrm{MB}$ & $\leq \pm 0.5$ & $\leq \pm 1.5$ & -0.64 & -0.52 & -0.58 \\
\hline & RMSE & $\leq \pm 2$ & $\leq \pm 2.5$ & 0.94 & 0.65 & 0.65 \\
\hline \multirow{3}{*}{$\begin{array}{l}\text { Wind Direction } \\
\text { (WD) [deg] }\end{array}$} & $\mathrm{MB}$ & $\leq \pm 10$ & $\mathrm{~N} / \mathrm{A}$ & -1.7 & -1.1 & 2.4 \\
\hline & $\mathrm{ME}$ & $\leq \pm 30$ & $\leq \pm 55$ & 9.2 & 8.4 & 7.1 \\
\hline & $\mathrm{MB}$ & $\leq \pm 1$ & $\mathrm{~N} / \mathrm{A}$ & 0.01 & -0.13 & -0.04 \\
\hline Humidity $\left[\mathrm{g} \mathrm{kg}^{-1}\right]$ & $\mathrm{ME}$ & $\leq \pm 2$ & $\mathrm{~N} / \mathrm{A}$ & 0.15 & 0.35 & 0.23 \\
\hline
\end{tabular}

S-Table 2. List of common AQS sites used.

\begin{tabular}{cccccc}
\hline Species & AQSID & Latitude & Longitude & Site Type & Site Name \\
\hline $\mathrm{O}_{3}$ & 530090013 & 48.29786 & -124.625 & RURAL & $\begin{array}{c}\text { CHEEKA PEAK } \\
\mathrm{O}_{3}\end{array}$ \\
$\mathrm{O}_{3}$ & 300298001 & 48.5103 & -113.997 & RURAL & GLACIER NATIONAL \\
$\mathrm{O}_{3}$ & 490571003 & 41.30361 & -111.988 & RARK \\
$\mathrm{O}_{3}$ & 160010010 & 43.6007 & -116.348 & URBAN AND CENTER & Harrisville \\
& 410090004 & 45.76853 & -122.772 & SITY Luke's Meridian \\
& & & & RURAL & SAUVIE ISLAND-SIS \\
\hline
\end{tabular}


This is a non peer-reviewed preprint submitted to EarthArxiv.

\begin{tabular}{|c|c|c|c|c|c|}
\hline $\mathrm{O}_{3}$ & 490490002 & 40.25361 & -111.663 & $\begin{array}{c}\text { URBAN AND CENTER } \\
\text { CITY }\end{array}$ & North Provo \\
\hline $\mathrm{O}_{3}$ & 530330017 & 47.49022 & -121.773 & RURAL & $\begin{array}{l}\text { NORTH BEND - } \\
\text { NORTH BEND WAY } \\
\text { CARUS }\end{array}$ \\
\hline $\mathrm{O}_{3}$ & 410050004 & 45.25928 & -122.588 & RURAL & $\begin{array}{c}\text { TRAILER/SPANGLER } \\
\text { RD }\end{array}$ \\
\hline $\mathrm{O}_{3}$ & 490495010 & 40.13634 & -111.661 & SUBURBAN & Spanish Fork \\
\hline $\mathrm{O}_{3}$ & 530630001 & 47.41645 & -117.53 & N/A & CHENEY - TURNBULL \\
\hline $\mathrm{O}_{3}$ & 530530012 & 46.7841 & -121.74 & RURAL & $\begin{array}{c}\text { MT RAINIER - } \\
\text { JACKSON VISITIORS } \\
\text { CENTER }\end{array}$ \\
\hline $\mathrm{O}_{3}$ & 410390060 & 44.02631 & -123.084 & $\begin{array}{c}\text { URBAN AND CENTER } \\
\text { CITY }\end{array}$ & $\begin{array}{l}\text { Eugene - AMAZON } \\
\text { PARK (EAP) }\end{array}$ \\
\hline $\mathrm{O}_{3}$ & 530330080 & 47.56824 & -122.309 & $\begin{array}{c}\text { URBAN AND CENTER } \\
\text { CITY }\end{array}$ & $\begin{array}{c}\text { SEATTLE - BEACON } \\
\text { HILL }\end{array}$ \\
\hline $\mathrm{O}_{3}$ & 410510080 & 45.49664 & -122.603 & SUBURBAN & $\begin{array}{c}\text { Portland - SE } \\
\text { Lafayette } \\
\text { ENUMCLAW - MUD }\end{array}$ \\
\hline $\mathrm{O}_{3}$ & 530330023 & 47.1411 & -121.938 & RURAL & $\begin{array}{l}\text { MTN (Army Corp of } \\
\text { Engineers site) }\end{array}$ \\
\hline $\mathrm{O}_{3}$ & 490110004 & 40.90297 & -111.884 & SUBURBAN & Bountiful Viewmont \\
\hline $\mathrm{O}_{3}$ & 530110011 & 45.61667 & -122.517 & SUBURBAN & $\begin{array}{l}\text { VANCOUVER - } \\
\text { BLAIRMONT DR }\end{array}$ \\
\hline $\mathrm{O}_{3}$ & 490030003 & 41.49271 & -112.019 & SUBURBAN & Brigham City \\
\hline $\mathrm{O}_{3}$ & 160010017 & 43.5776 & -116.178 & SUBURBAN & $\begin{array}{l}\text { SAMPLER LOCATED } \\
\text { ON SCHOOL ROOF- } \\
\text { TOP IN SUBURBAN } \\
\text { MOSTLY RESDNT'L } \\
\text { AREA }\end{array}$ \\
\hline $\mathrm{O}_{3}$ & 410391007 & 43.8345 & -123.035 & RURAL & Eugene - Saginaw \\
\hline $\mathrm{O}_{3}$ & 490353006 & 40.73639 & -111.872 & SUBURBAN & $\begin{array}{c}\text { Hawthorne } \\
\text { Craters of the Moon }\end{array}$ \\
\hline $\mathrm{O}_{3}$ & 160230101 & 43.46056 & -113.562 & RURAL & $\begin{array}{l}\text { National Monument, } \\
\text { Visitor Center }\end{array}$ \\
\hline $\mathrm{O}_{3}$ & 530730005 & 48.95074 & -122.554 & RURAL & CUSTER - LOOMIS \\
\hline $\mathrm{O}_{3}$ & 490570002 & 41.20632 & -111.976 & $\begin{array}{l}\text { URBAN AND CENTER } \\
\text { CITY }\end{array}$ & Ogden \\
\hline $\mathrm{O}_{3}$ & 530330010 & 47.5525 & -122.065 & SUBURBAN & $\begin{array}{l}\text { ISSAQUAH - LAKE } \\
\text { SAMMAMISH } \\
\text { (Wiithin Lake } \\
\text { Sammamish State } \\
\text { Park) }\end{array}$ \\
\hline $\mathrm{PM}_{2.5}$ & 530150015 & 46.13944 & -122.962 & SUBURBAN & $\begin{array}{l}\text { LONGVIEW - 30TH } \\
\text { AVE }\end{array}$ \\
\hline $\mathrm{PM}_{2.5}$ & 410610119 & 45.339 & -118.095 & $\begin{array}{c}\text { URBAN AND CENTER } \\
\text { CITY }\end{array}$ & $\begin{array}{l}\text { LA GRANDE ASH } \\
\text { STREET }\end{array}$ \\
\hline $\mathrm{PM}_{2.5}$ & 530610005 & 47.8064 & -122.317 & SUBURBAN & LYNNWOOD - 212TH \\
\hline $\mathrm{PM}_{2.5}$ & 160090010 & 47.31658 & -116.571 & $\begin{array}{c}\text { URBAN AND CENTER } \\
\text { CITY }\end{array}$ & $\begin{array}{l}\text { USFS AT CENTER AND } \\
\text { 9TH ST, ST. MARIES, } \\
\text { BENEWAH COUNTY. }\end{array}$ \\
\hline
\end{tabular}


This is a non peer-reviewed preprint submitted to EarthArxiv.

\begin{tabular}{|c|c|c|c|c|c|}
\hline $\mathrm{PM}_{2.5}$ & 410170120 & 44.06392 & -121.313 & $\begin{array}{c}\text { URBAN AND CENTER } \\
\text { CITY }\end{array}$ & $\begin{array}{c}\text { OPEN } \\
\text { FIELD/RESIDENTIAL } \\
\text { AREA BY DESCHUTES } \\
\text { RIVER. CITY PUMP } \\
\text { STATION. }\end{array}$ \\
\hline $\mathrm{PM}_{2.5}$ & 530470009 & 48.36451 & -120.121 & RURAL & TWISP - GLOVER ST \\
\hline $\mathrm{PM}_{2.5}$ & 530531018 & 47.14 & -122.3 & SUBURBAN & PUYALLUP - 128TH ST \\
\hline $\mathrm{PM}_{2.5}$ & 530330017 & 47.49022 & -121.773 & RURAL & $\begin{array}{l}\text { NORTH BEND - } \\
\text { NORTH BEND WAY } \\
\text { CARUS }\end{array}$ \\
\hline $\mathrm{PM}_{2.5}$ & 410050004 & 45.25928 & -122.588 & RURAL & $\begin{array}{c}\text { TRAILER/SPANGLER } \\
\text { RD }\end{array}$ \\
\hline $\mathrm{PM}_{2.5}$ & 410470041 & 44.94311 & -123.006 & $\begin{array}{c}\text { URBAN AND CENTER } \\
\text { CITY }\end{array}$ & $\begin{array}{l}\text { Salem - State } \\
\text { Hospital }\end{array}$ \\
\hline $\mathrm{PM}_{2.5}$ & 410390060 & 44.02631 & -123.084 & $\begin{array}{c}\text { URBAN AND CENTER } \\
\text { CITY }\end{array}$ & $\begin{array}{l}\text { Eugene - AMAZON } \\
\text { PARK (EAP) }\end{array}$ \\
\hline $\mathrm{PM}_{2.5}$ & 530330080 & 47.56824 & -122.309 & $\begin{array}{l}\text { URBAN AND CENTER } \\
\text { CITY }\end{array}$ & $\begin{array}{c}\text { SEATTLE - BEACON } \\
\text { HILL }\end{array}$ \\
\hline $\mathrm{PM}_{2.5}$ & 410510080 & 45.49664 & -122.603 & SUBURBAN & $\begin{array}{l}\text { Portland - SE } \\
\text { Lafayette } \\
\text { USFS COMPOUND }\end{array}$ \\
\hline $\mathrm{PM}_{2.5}$ & 160490002 & 45.93127 & -116.116 & RURAL & $\begin{array}{c}\text { ON EAST EDGE OF } \\
\text { TOWN }\end{array}$ \\
\hline $\mathrm{PM}_{2.5}$ & 530330057 & 47.55975 & -122.338 & SUBURBAN & $\begin{array}{l}\text { SEATTLE - } \\
\text { DUWAMISH }\end{array}$ \\
\hline $\mathrm{PM}_{2.5}$ & 530670013 & 47.0294 & -122.822 & SUBURBAN & LACEY - COLLEGE ST \\
\hline $\mathrm{PM}_{2.5}$ & 410670004 & 45.5285 & -122.972 & SUBURBAN & Hillsboro - Hare Field \\
\hline $\mathrm{PM}_{2.5}$ & 530530031 & 47.2656 & -122.386 & SUBURBAN & $\begin{array}{c}\text { TACOMA - } \\
\text { ALEXANDER AVE } \\
\text { R\&P } 1400 \text { PM2.5 }\end{array}$ \\
\hline $\mathrm{PM}_{2.5}$ & 160570005 & 46.72182 & -116.96 & RURAL & $\begin{array}{c}\text { TEOM. UNIVERSITY } \\
\text { OF IDAHO PLANT } \\
\text { SCIENCES SITE. } \\
\text { SUNSET PARK }\end{array}$ \\
\hline $\mathrm{PM}_{2.5}$ & 160690012 & 46.40835 & -116.993 & SUBURBAN & $\begin{array}{l}\text { LOCATION, BETWEEN } \\
\text { CITY CENTER AND } \\
\text { POTLACH CORP., }\end{array}$ \\
\hline $\mathrm{PM}_{2.5}$ & 410650007 & 45.60242 & -121.203 & $\begin{array}{c}\text { URBAN AND CENTER } \\
\text { CITY }\end{array}$ & $\begin{array}{c}\text { The Dalles - Cherry } \\
\text { Drive }\end{array}$ \\
\hline $\mathrm{PM}_{2.5}$ & 530770016 & 46.37543 & -120.729 & RURAL & $\begin{array}{c}\text { White Swan-Yakama } \\
\text { Tribe }\end{array}$ \\
\hline $\mathrm{PM}_{2.5}$ & 530330024 & 47.755 & -122.281 & SUBURBAN & $\begin{array}{l}\text { LAKE FOREST PARK } \\
\text { TOWNE CENTER }\end{array}$ \\
\hline $\mathrm{PM}_{2.5}$ & 490494001 & 40.34139 & -111.714 & SUBURBAN & Lindon \\
\hline $\mathrm{PM}_{2.5}$ & 530750006 & 47.23136 & -117.369 & $\begin{array}{c}\text { URBAN AND CENTER } \\
\text { CITY }\end{array}$ & $\begin{array}{c}\text { ROSALIA - JOSEPHINE } \\
\text { ST } \\
\text { SPOKANE - }\end{array}$ \\
\hline $\mathrm{PM}_{2.5}$ & 530650002 & 47.88528 & -117.989 & SUBURBAN & $\begin{array}{l}\text { WELLPINIT FORD RD } \\
\text { (SPOKANE TRIBE) }\end{array}$ \\
\hline $\mathrm{PM}_{2.5}$ & 410432002 & 44.3958 & -122.731 & RURAL & $\begin{array}{c}\text { Sweet Home - FD } \\
\text { (SFD) }\end{array}$ \\
\hline
\end{tabular}


This is a non peer-reviewed preprint submitted to EarthArxiv.

\begin{tabular}{|c|c|c|c|c|c|}
\hline $\mathrm{PM}_{2.5}$ & 530611007 & 48.05432 & -122.172 & SUBURBAN & $\begin{array}{l}\text { MARYSVILLE - 7TH } \\
\text { AVE (Marysville } \\
\text { Junior High) }\end{array}$ \\
\hline $\mathrm{PM}_{2.5}$ & 490490002 & 40.25361 & -111.663 & $\begin{array}{c}\text { URBAN AND CENTER } \\
\text { CITY }\end{array}$ & North Provo \\
\hline $\mathrm{PM}_{2.5}$ & 410010004 & 44.78822 & -117.845 & SUBURBAN & $\begin{array}{l}\text { US FOREST SERVICE } \\
\text { OFFICE - BAKER CITY }\end{array}$ \\
\hline $\mathrm{PM}_{2.5}$ & 410290133 & 42.31411 & -122.879 & $\begin{array}{c}\text { URBAN AND CENTER } \\
\text { CITY }\end{array}$ & $\begin{array}{l}\text { Medford - Grant \& } \\
\text { Belmont Sts. (MGB) }\end{array}$ \\
\hline $\mathrm{PM}_{2.5}$ & 530750005 & 46.8153 & -117.874 & RURAL & LACAROSSE - HILL ST \\
\hline $\mathrm{PM}_{2.5}$ & 410130100 & 44.29979 & -120.845 & RURAL & $\begin{array}{c}\text { Prineville - Davidson } \\
\text { Park }\end{array}$ \\
\hline $\mathrm{PM}_{2.5}$ & 410190002 & 43.2266 & -123.365 & SUBURBAN & $\begin{array}{c}\text { ROSEBURG, OR; BLM } \\
\text { OFFICE - RGV }\end{array}$ \\
\hline $\mathrm{PM}_{2.5}$ & 530630021 & 47.67248 & -117.365 & $\begin{array}{c}\text { URBAN AND CENTER } \\
\text { CITY }\end{array}$ & $\begin{array}{c}\text { SPOKANE - AUGUSTA } \\
\text { AVE }\end{array}$ \\
\hline $\mathrm{PM}_{2.5}$ & 490030003 & 41.49271 & -112.019 & SUBURBAN & Brigham City \\
\hline $\mathrm{PM}_{2.5}$ & 410590121 & 45.65223 & -118.823 & SUBURBAN & $\begin{array}{c}\text { Pendleton - McKay } \\
\text { Creek }\end{array}$ \\
\hline $\mathrm{PM}_{2.5}$ & 530272002 & 46.97228 & -123.832 & SUBURBAN & $\begin{array}{l}\text { ABERDEEN - } \\
\text { DIVISION ST }\end{array}$ \\
\hline $\mathrm{PM}_{2.5}$ & 410250003 & 43.58925 & -119.049 & $\begin{array}{c}\text { URBAN AND CENTER } \\
\text { CITY }\end{array}$ & $\begin{array}{c}\text { Burns - Washington } \\
\text { Park (BWS) }\end{array}$ \\
\hline $\mathrm{PM}_{2.5}$ & 530530029 & 47.1864 & -122.452 & SUBURBAN & TACOMA - L STREET \\
\hline $\mathrm{PM}_{2.5}$ & 410430009 & 44.61569 & -123.091 & $\begin{array}{c}\text { URBAN AND CENTER } \\
\text { CITY }\end{array}$ & $\begin{array}{l}\text { Albany - Caliapooia } \\
\text { School }\end{array}$ \\
\hline $\mathrm{PM}_{2.5}$ & 530610020 & 48.2469 & -121.603 & $\begin{array}{c}\text { URBAN AND CENTER } \\
\text { CITY }\end{array}$ & $\begin{array}{c}\text { DARRINGTON - FIR ST } \\
\text { (Darrington High } \\
\text { School) }\end{array}$ \\
\hline $\mathrm{PM}_{2.5}$ & 530331011 & 47.53091 & -122.321 & $\begin{array}{c}\text { URBAN AND CENTER } \\
\text { CITY }\end{array}$ & $\begin{array}{c}\text { SEATTLE - SOUTH } \\
\text { PARK \#2 }\end{array}$ \\
\hline $\mathrm{PM}_{2.5}$ & 530410004 & 46.66409 & -122.967 & $\begin{array}{c}\text { URBAN AND CENTER } \\
\text { CITY }\end{array}$ & $\begin{array}{c}\text { CHEHALIS - MARKET } \\
\text { BLVD }\end{array}$ \\
\hline $\mathrm{PM}_{2.5}$ & 530251002 & 47.1303 & -119.274 & $\begin{array}{c}\text { URBAN AND CENTER } \\
\text { CITY }\end{array}$ & $\begin{array}{l}\text { MOSES LAKE - } \\
\text { BALSAM ST }\end{array}$ \\
\hline $\mathrm{PM}_{2.5}$ & 160090011 & 47.33861 & -116.886 & RURAL & 0 \\
\hline $\mathrm{PM}_{2.5}$ & 410330114 & 42.43414 & -123.348 & SUBURBAN & $\begin{array}{l}\text { GRANTS PASS } \\
\text { PARKSIDE SCHOOL } \\
\text { PROVOLT, OR AT }\end{array}$ \\
\hline $\mathrm{PM}_{2.5}$ & 410330011 & 42.29009 & -123.232 & RURAL & $\begin{array}{l}\text { THE BLM SEED } \\
\text { ORCHARD }\end{array}$ \\
\hline $\mathrm{PM}_{2.5}$ & 490570002 & 41.20632 & -111.976 & $\begin{array}{c}\text { URBAN AND CENTER } \\
\text { CITY }\end{array}$ & Ogden \\
\hline $\mathrm{PM}_{2.5}$ & 160790017 & 47.53639 & -116.237 & $\begin{array}{c}\text { URBAN AND CENTER } \\
\text { CITY }\end{array}$ & 0 \\
\hline $\mathrm{PM}_{2.5}$ & 530370002 & 46.99364 & -120.545 & $\begin{array}{c}\text { URBAN AND CENTER } \\
\text { CITY }\end{array}$ & $\begin{array}{c}\text { ELLENSBURG - RUBY } \\
\text { ST }\end{array}$ \\
\hline $\mathrm{PM}_{2.5}$ & 410330036 & 42.1617 & -123.648 & RURAL & $\begin{array}{c}\text { Cave Junction - USFS } \\
\text { Office (CJFS) }\end{array}$ \\
\hline $\mathrm{PM}_{2.5}$ & 530330037 & 47.61311 & -122.202 & SUBURBAN & $\begin{array}{c}\text { BELLEVUE - } \\
\text { BELLEVUE WAY NE }\end{array}$ \\
\hline
\end{tabular}


This is a non peer-reviewed preprint submitted to EarthArxiv.

\begin{tabular}{|c|c|c|c|c|c|}
\hline $\mathrm{PM}_{2.5}$ & 410230002 & 44.418 & -118.951 & RURAL & $\begin{array}{l}\text { John Day Dayton } \\
\text { (JDD) }\end{array}$ \\
\hline $\mathrm{PM}_{2.5}$ & 160150001 & 43.82291 & -115.84 & RURAL & $\begin{array}{c}\text { SITE IS AT SHERRIF'S } \\
\text { OFFICE }\end{array}$ \\
\hline $\mathrm{PM}_{2.5}$ & 530090015 & 48.36606 & -124.61 & $\begin{array}{c}\text { URBAN AND CENTER } \\
\text { CITY }\end{array}$ & $\begin{array}{c}\text { Neah Bay 2-Makah } \\
\text { Tribe }\end{array}$ \\
\hline $\mathrm{PM}_{2.5}$ & 410290019 & 42.62323 & -122.81 & RURAL & $\begin{array}{c}\text { SHADY COVE School } \\
\text { (SCS) }\end{array}$ \\
\hline $\mathrm{PM}_{2.5}$ & 300490026 & 46.65876 & -112.013 & SUBURBAN & $\begin{array}{c}\text { ROSSITER PUMP } \\
\text { HOUSE }\end{array}$ \\
\hline $\mathrm{PM}_{2.5}$ & 530050002 & 46.21835 & -119.204 & $\begin{array}{c}\text { URBAN AND CENTER } \\
\text { CITY }\end{array}$ & $\begin{array}{l}\text { KENNEWICK - } \\
\text { METALINE }\end{array}$ \\
\hline $\mathrm{PM}_{2.5}$ & 530030004 & 46.42542 & -117.06 & SUBURBAN & $\begin{array}{c}\text { CLARKSTON - 13TH } \\
\text { ST }\end{array}$ \\
\hline $\mathrm{PM}_{2.5}$ & 530310003 & 48.12919 & -122.779 & SUBURBAN & $\begin{array}{l}\text { Port Townsend-San } \\
\text { Juan }\end{array}$ \\
\hline $\mathrm{PM}_{2.5}$ & 300530018 & 48.39155 & -115.553 & $\begin{array}{c}\text { URBAN AND CENTER } \\
\text { CITY }\end{array}$ & $\begin{array}{l}\text { Libby Courthouse } \\
\text { Annex }\end{array}$ \\
\hline $\mathrm{PM}_{2.5}$ & 530770009 & 46.59806 & -120.499 & $\begin{array}{l}\text { URBAN AND CENTER } \\
\text { CITY }\end{array}$ & YAKIMA - 4TH AVE \\
\hline $\mathrm{PM}_{2.5}$ & 530130002 & 46.318 & -117.985 & RURAL & DAYTON - W MAIN \\
\hline $\mathrm{PM}_{2.5}$ & 410170004 & 44.2921 & -121.556 & RURAL & $\begin{array}{c}\text { Sisters Forest Service } \\
\text { Station (SFS) }\end{array}$ \\
\hline $\mathrm{PM}_{2.5}$ & 490353006 & 40.73639 & -111.872 & SUBURBAN & Hawthorne \\
\hline $\mathrm{PM}_{2.5}$ & 530570015 & 48.4102 & -122.338 & SUBURBAN & $\begin{array}{c}\text { MT VERNON - 2ND } \\
\text { AVE }\end{array}$ \\
\hline $\mathrm{PM}_{2.5}$ & 530730015 & 48.76278 & -122.44 & SUBURBAN & $\begin{array}{c}\text { BELLINGHAM - YEW } \\
\text { STREET }\end{array}$ \\
\hline $\mathrm{PM}_{2.5}$ & 530470010 & 48.47724 & -120.191 & RURAL & $\begin{array}{l}\text { WINTHROP - } \\
\text { CHEWUCH RD } \\
\text { SITE IS MIDWAY }\end{array}$ \\
\hline $\mathrm{PM}_{2.5}$ & 160270002 & 43.58031 & -116.563 & $\begin{array}{c}\text { URBAN AND CENTER } \\
\text { CITY }\end{array}$ & $\begin{array}{l}\text { BETWEEN A MAJOR } \\
\text { STREET AND A LOCAL } \\
\text { STREET. }\end{array}$ \\
\hline $\mathrm{PM}_{2.5}$ & 530750003 & 46.72447 & -117.18 & SUBURBAN & $\begin{array}{c}\text { PULLMAN - DEXTER } \\
\text { AVE } 4\end{array}$ \\
\hline $\mathrm{PM}_{2.5}$ & 530770015 & 46.38024 & -120.333 & $\begin{array}{l}\text { URBAN AND CENTER } \\
\text { CITY }\end{array}$ & $\begin{array}{l}\text { TOPPENISH - WARD } \\
\text { RD (YAKAMA TRIBE) }\end{array}$ \\
\hline $\mathrm{PM}_{2.5}$ & 410392013 & 43.74435 & -122.48 & SUBURBAN & Oakridge - (OAK) \\
\hline $\mathrm{PM}_{2.5}$ & 160590004 & 45.1819 & -113.89 & RURAL & $\begin{array}{c}\text { SALMON IDAHO, } \\
\text { OPEN FIELD, GRASS } \\
\text { COVERED AND } \\
\text { PASTURE }\end{array}$ \\
\hline $\mathrm{PM}_{2.5}$ & 410370001 & 42.18922 & -120.354 & RURAL & $\begin{array}{c}\text { Lakeview, CENTER \& } \\
\text { M ST. (LCM) }\end{array}$ \\
\hline $\mathrm{PM}_{2.5}$ & 530090013 & 48.29786 & -124.625 & RURAL & CHEEKA PEAK \\
\hline $\mathrm{PM}_{2.5}$ & 530470013 & 48.39999 & -119.519 & SUBURBAN & Omak-Colville Tribe \\
\hline $\mathrm{PM}_{2.5}$ & 530110022 & 45.8639 & -122.411 & RURAL & YACOLT - YACOLT RD \\
\hline $\mathrm{PM}_{2.5}$ & 160010010 & 43.6007 & -116.348 & $\begin{array}{l}\text { URBAN AND CENTER } \\
\text { CITY }\end{array}$ & St. Luke's Meridian \\
\hline $\mathrm{PM}_{2.5}$ & 410090004 & 45.76853 & -122.772 & RURAL & SAUVIE ISLAND-SIS \\
\hline
\end{tabular}


This is a non peer-reviewed preprint submitted to EarthArxiv.

\begin{tabular}{|c|c|c|c|c|c|}
\hline & & & & & NW CORNER OF \\
\hline & & & & & ATHLETIC FIELD AT \\
\hline $\mathrm{PM}_{2.5}$ & 410030013 & 44.5884 & -123.267 & SUBURBAN & $\begin{array}{l}\text { HIGHLAND VIEW } \\
\text { INTERMEDIATE } \\
\text { SCHOOL }\end{array}$ \\
\hline $\mathrm{PM}_{2.5}$ & 530332004 & 47.38611 & -122.23 & $\begin{array}{c}\text { URBAN AND CENTER } \\
\text { CITY }\end{array}$ & $\begin{array}{c}\text { KENT - JAMES \& } \\
\text { CENTRAL }\end{array}$ \\
\hline $\mathrm{PM}_{2.5}$ & 530070010 & 47.59886 & -120.665 & SUBURBAN & $\begin{array}{l}\text { LEAVENWORTH - } \\
\text { EVANS ST }\end{array}$ \\
\hline $\mathrm{PM}_{2.5}$ & 530630047 & 47.69978 & -117.426 & $\begin{array}{l}\text { URBAN AND CENTER } \\
\text { CITY }\end{array}$ & $\begin{array}{c}\text { SPOKANE - MONROE } \\
\text { ST }\end{array}$ \\
\hline $\mathrm{PM}_{2.5}$ & 410630001 & 45.42635 & -117.296 & RURAL & Enterprise - USFS \\
\hline $\mathrm{PM}_{2.5}$ & 410670111 & 45.47019 & -122.816 & $\begin{array}{c}\text { URBAN AND CENTER } \\
\text { CITY }\end{array}$ & $\begin{array}{c}\text { Beaverton - Highland } \\
\text { Park }\end{array}$ \\
\hline $\mathrm{PM}_{2.5}$ & 530010003 & 47.12 & -118.382 & RURAL & RITZVILLE - ALDER ST \\
\hline $\mathrm{PM}_{2.5}$ & 530210002 & 46.5754 & -119.002 & RURAL & MESA - PEPOIT WAY \\
\hline $\mathrm{PM}_{2.5}$ & 410350004 & 42.1903 & -121.731 & SUBURBAN & $\begin{array}{l}\text { Klamath Falls - } \\
\text { Peterson School }\end{array}$ \\
\hline $\mathrm{PM}_{2.5}$ & 530710005 & 46.05881 & -118.351 & SUBURBAN & $\begin{array}{c}\text { WALLA WALL - } 12 \mathrm{TH} \\
\text { ST }\end{array}$ \\
\hline $\mathrm{PM}_{2.5}$ & 530450007 & 47.21355 & -123.101 & $\begin{array}{c}\text { URBAN AND CENTER } \\
\text { CITY }\end{array}$ & Shelton - W Franklin \\
\hline
\end{tabular}

S-Table 3. List of common AQS sites used and statistics per AIRPACT version.

\begin{tabular}{cccccccccc}
\hline Version & Species & Unit & AQSID & $\begin{array}{c}\text { Forecast } \\
\text { Mean }\end{array}$ & $\begin{array}{c}\text { Observation } \\
\text { Mean }\end{array}$ & FB [\%] & FE [\%] & RMSE & $\mathrm{R}^{2}[-]$ \\
\hline AP-3 & $\mathrm{O}_{3}$ & $\mathrm{ppb}$ & 530090013 & 36 & 36 & 0 & 15 & 7 & 0.46 \\
AP-3 & $\mathrm{O}_{3}$ & $\mathrm{ppb}$ & 300298001 & 41 & 35 & 19 & 24 & 11 & 0.27 \\
AP-3 & $\mathrm{O}_{3}$ & $\mathrm{ppb}$ & 490571003 & 57 & 54 & 5 & 12 & 9 & 0.4 \\
AP-3 & $\mathrm{O}_{3}$ & $\mathrm{ppb}$ & 160010010 & 43 & 42 & 3 & 15 & 8 & 0.58 \\
AP-3 & $\mathrm{O}_{3}$ & $\mathrm{ppb}$ & 410090004 & 38 & 33 & 15 & 22 & 10 & 0.46 \\
AP-3 & $\mathrm{O}_{3}$ & $\mathrm{ppb}$ & 490490002 & 49 & 43 & 19 & 24 & 12 & 0.57 \\
AP-3 & $\mathrm{O}_{3}$ & $\mathrm{ppb}$ & 530330017 & 41 & 35 & 19 & 25 & 11 & 0.45 \\
AP-3 & $\mathrm{O}_{3}$ & $\mathrm{ppb}$ & 410050004 & 38 & 36 & 5 & 17 & 7 & 0.6 \\
AP-3 & $\mathrm{O}_{3}$ & $\mathrm{ppb}$ & 490495010 & 60 & 54 & 10 & 14 & 10 & 0.26 \\
AP-3 & $\mathrm{O}_{3}$ & $\mathrm{ppb}$ & 530630001 & 46 & 48 & -4 & 10 & 6 & 0.55 \\
AP-3 & $\mathrm{O}_{3}$ & $\mathrm{ppb}$ & 530530012 & 42 & 41 & 3 & 15 & 8 & 0.22 \\
AP-3 & $\mathrm{O}_{3}$ & $\mathrm{ppb}$ & 410390060 & 41 & 35 & 16 & 21 & 10 & 0.56 \\
AP-3 & $\mathrm{O}_{3}$ & $\mathrm{ppb}$ & 530330080 & 27 & 26 & 1 & 33 & 10 & 0.3 \\
AP-3 & $\mathrm{O}_{3}$ & $\mathrm{ppb}$ & 410510080 & 32 & 29 & 12 & 27 & 9 & 0.53 \\
AP-3 & $\mathrm{O}_{3}$ & $\mathrm{ppb}$ & 530330023 & 43 & 37 & 17 & 23 & 10 & 0.54 \\
AP-3 & $\mathrm{O}_{3}$ & $\mathrm{ppb}$ & 490110004 & 57 & 47 & 20 & 22 & 13 & 0.55 \\
AP-3 & $\mathrm{O}_{3}$ & $\mathrm{ppb}$ & 530110011 & 41 & 37 & 11 & 20 & 10 & 0.51 \\
AP-3 & $\mathrm{O}_{3}$ & $\mathrm{ppb}$ & 490030003 & 57 & 54 & 6 & 12 & 8 & 0.39 \\
AP-3 & $\mathrm{O}_{3}$ & $\mathrm{ppb}$ & 160010017 & 52 & 49 & 5 & 15 & 10 & 0.23 \\
AP-3 & $\mathrm{O}_{3}$ & $\mathrm{ppb}$ & 410391007 & 42 & 36 & 17 & 21 & 10 & 0.54 \\
\hline
\end{tabular}


This is a non peer-reviewed preprint submitted to EarthArxiv.

\begin{tabular}{|c|c|c|c|c|c|c|c|c|c|}
\hline AP-3 & $\mathrm{O}_{3}$ & $\mathrm{ppb}$ & 490353006 & 45 & 42 & 11 & 22 & 10 & 0.67 \\
\hline AP-3 & $\mathrm{O}_{3}$ & $\mathrm{ppb}$ & 160230101 & 48 & 46 & 5 & 12 & 7 & 0.36 \\
\hline AP-3 & $\mathrm{O}_{3}$ & $\mathrm{ppb}$ & 530730005 & 37 & 31 & 18 & 24 & 10 & 0.35 \\
\hline AP-3 & $\mathrm{O}_{3}$ & $\mathrm{ppb}$ & 490570002 & 48 & 42 & 18 & 24 & 11 & 0.63 \\
\hline AP-3 & $\mathrm{O}_{3}$ & $\mathrm{ppb}$ & 530330010 & 42 & 37 & 16 & 22 & 11 & 0.45 \\
\hline AP-4 & $\mathrm{O}_{3}$ & $\mathrm{ppb}$ & 530090013 & 36 & 37 & -4 & 15 & 6 & 0.58 \\
\hline AP-4 & $\mathrm{O}_{3}$ & $\mathrm{ppb}$ & 300298001 & 43 & 35 & 23 & 27 & 12 & 0.26 \\
\hline AP-4 & $\mathrm{O}_{3}$ & $\mathrm{ppb}$ & 490571003 & 52 & 47 & 11 & 17 & 11 & 0.54 \\
\hline AP-4 & $\mathrm{O}_{3}$ & $\mathrm{ppb}$ & 160010010 & 44 & 37 & 20 & 26 & 12 & 0.5 \\
\hline AP-4 & $\mathrm{O}_{3}$ & $\mathrm{ppb}$ & 410090004 & 39 & 35 & 9 & 23 & 12 & 0.46 \\
\hline AP-4 & $\mathrm{O}_{3}$ & $\mathrm{ppb}$ & 490490002 & 51 & 43 & 22 & 25 & 14 & 0.55 \\
\hline AP-4 & $\mathrm{O}_{3}$ & $\mathrm{ppb}$ & 530330017 & 45 & 36 & 20 & 26 & 14 & 0.45 \\
\hline AP-4 & $\mathrm{O}_{3}$ & $\mathrm{ppb}$ & 410050004 & 43 & 41 & 1 & 20 & 11 & 0.59 \\
\hline AP-4 & $\mathrm{O}_{3}$ & $\mathrm{ppb}$ & 490495010 & 53 & 45 & 19 & 22 & 12 & 0.55 \\
\hline AP-4 & $\mathrm{O}_{3}$ & $\mathrm{ppb}$ & 530630001 & 46 & 46 & 0 & 16 & 10 & 0.2 \\
\hline AP-4 & $\mathrm{O}_{3}$ & $\mathrm{ppb}$ & 530530012 & 49 & 42 & 14 & 19 & 14 & 0.06 \\
\hline AP-4 & $\mathrm{O}_{3}$ & $\mathrm{ppb}$ & 410390060 & 39 & 37 & 4 & 19 & 10 & 0.52 \\
\hline AP-4 & $\mathrm{O}_{3}$ & $\mathrm{ppb}$ & 530330080 & 26 & 27 & -8 & 35 & 9 & 0.51 \\
\hline AP-4 & $\mathrm{O}_{3}$ & $\mathrm{ppb}$ & 410510080 & 35 & 29 & 18 & 29 & 10 & 0.56 \\
\hline AP-4 & $\mathrm{O}_{3}$ & $\mathrm{ppb}$ & 530330023 & 48 & 39 & 17 & 24 & 14 & 0.57 \\
\hline AP-4 & $\mathrm{O}_{3}$ & $\mathrm{ppb}$ & 490110004 & 49 & 40 & 25 & 27 & 13 & 0.64 \\
\hline AP-4 & $\mathrm{O}_{3}$ & $\mathrm{ppb}$ & 530110011 & 40 & 36 & 4 & 23 & 11 & 0.56 \\
\hline AP-4 & $\mathrm{O}_{3}$ & $\mathrm{ppb}$ & 490030003 & 55 & 49 & 12 & 17 & 12 & 0.3 \\
\hline AP-4 & $\mathrm{O}_{3}$ & $\mathrm{ppb}$ & 160010017 & 51 & 47 & 7 & 23 & 16 & 0.06 \\
\hline AP-4 & $\mathrm{O}_{3}$ & $\mathrm{ppb}$ & 410391007 & 43 & 39 & 10 & 20 & 11 & 0.51 \\
\hline AP-4 & $\mathrm{O}_{3}$ & $\mathrm{ppb}$ & 490353006 & 46 & 42 & 9 & 20 & 11 & 0.71 \\
\hline AP-4 & $\mathrm{O}_{3}$ & $\mathrm{ppb}$ & 160230101 & 49 & 44 & 11 & 16 & 11 & 0.19 \\
\hline AP-4 & $\mathrm{O}_{3}$ & ppb & 530730005 & 39 & 31 & 17 & 26 & 13 & 0.33 \\
\hline AP-4 & $\mathrm{O}_{3}$ & $\mathrm{ppb}$ & 490570002 & 50 & 43 & 18 & 22 & 11 & 0.62 \\
\hline AP-4 & $\mathrm{O}_{3}$ & $\mathrm{ppb}$ & 530330010 & 40 & 35 & 13 & 24 & 13 & 0.46 \\
\hline AP-5 & $\mathrm{O}_{3}$ & $\mathrm{ppb}$ & 530090013 & 34 & 36 & -8 & 16 & 7 & 0.54 \\
\hline AP-5 & $\mathrm{O}_{3}$ & $\mathrm{ppb}$ & 300298001 & 42 & 36 & 17 & 22 & 12 & 0.19 \\
\hline AP-5 & $\mathrm{O}_{3}$ & $\mathrm{ppb}$ & 490571003 & 50 & 47 & 10 & 19 & 11 & 0.49 \\
\hline AP-5 & $\mathrm{O}_{3}$ & $\mathrm{ppb}$ & 160010010 & 41 & 40 & 6 & 18 & 10 & 0.46 \\
\hline AP-5 & $\mathrm{O}_{3}$ & $\mathrm{ppb}$ & 410090004 & 35 & 34 & 1 & 17 & 9 & 0.46 \\
\hline AP-5 & $\mathrm{O}_{3}$ & $\mathrm{ppb}$ & 490490002 & 51 & 43 & 21 & 24 & 13 & 0.54 \\
\hline AP-5 & $\mathrm{O}_{3}$ & ppb & 530330017 & 39 & 36 & 9 & 20 & 12 & 0.35 \\
\hline AP-5 & $\mathrm{O}_{3}$ & $\mathrm{ppb}$ & 410050004 & 37 & 38 & -5 & 16 & 7 & 0.56 \\
\hline AP-5 & $\mathrm{O}_{3}$ & ppb & 490495010 & 50 & 46 & 10 & 17 & 13 & 0.3 \\
\hline AP-5 & $\mathrm{O}_{3}$ & $\mathrm{ppb}$ & 530630001 & 44 & 44 & -2 & 15 & 15 & 0.16 \\
\hline AP-5 & $\mathrm{O}_{3}$ & $\mathrm{ppb}$ & 530530012 & 46 & 43 & 6 & 14 & 9 & 0.23 \\
\hline AP-5 & $\mathrm{O}_{3}$ & $\mathrm{ppb}$ & 410390060 & 36 & 37 & -2 & 17 & 8 & 0.52 \\
\hline AP-5 & $\mathrm{O}_{3}$ & $\mathrm{ppb}$ & 530330080 & 27 & 29 & -9 & 25 & 8 & 0.5 \\
\hline
\end{tabular}


This is a non peer-reviewed preprint submitted to EarthArxiv.

\begin{tabular}{|c|c|c|c|c|c|c|c|c|c|}
\hline AP-5 & $\mathrm{O}_{3}$ & $\mathrm{ppb}$ & 410510080 & 35 & 32 & 12 & 23 & 9 & 0.45 \\
\hline AP-5 & $\mathrm{O}_{3}$ & $\mathrm{ppb}$ & 530330023 & 41 & 40 & 5 & 19 & 12 & 0.44 \\
\hline AP-5 & $\mathrm{O}_{3}$ & $\mathrm{ppb}$ & 490110004 & 50 & 45 & 14 & 19 & 11 & 0.56 \\
\hline AP-5 & $\mathrm{O}_{3}$ & $\mathrm{ppb}$ & 530110011 & 37 & 36 & 1 & 17 & 9 & 0.53 \\
\hline AP-5 & $\mathrm{O}_{3}$ & $\mathrm{ppb}$ & 490030003 & 51 & 43 & 19 & 24 & 13 & 0.35 \\
\hline AP-5 & $\mathrm{O}_{3}$ & $\mathrm{ppb}$ & 160010017 & 48 & 47 & 5 & 21 & 13 & 0.14 \\
\hline AP-5 & $\mathrm{O}_{3}$ & $\mathrm{ppb}$ & 410391007 & 38 & 37 & 5 & 18 & 9 & 0.44 \\
\hline AP-5 & $\mathrm{O}_{3}$ & $\mathrm{ppb}$ & 490353006 & 48 & 45 & 8 & 17 & 11 & 0.58 \\
\hline AP-5 & $\mathrm{O}_{3}$ & $\mathrm{ppb}$ & 160230101 & 47 & 45 & 6 & 14 & 10 & 0.16 \\
\hline AP-5 & $\mathrm{O}_{3}$ & $\mathrm{ppb}$ & 530730005 & 36 & 34 & 4 & 20 & 12 & 0.18 \\
\hline AP-5 & $\mathrm{O}_{3}$ & $\mathrm{ppb}$ & 490570002 & 48 & 46 & 10 & 20 & 11 & 0.56 \\
\hline AP-5 & $\mathrm{O}_{3}$ & $\mathrm{ppb}$ & 530330010 & 34 & 36 & -6 & 22 & 13 & 0.27 \\
\hline AP-3 & $\mathrm{PM}_{2.5}$ & $\mu \mathrm{g} \mathrm{m}^{-3}$ & 530150015 & 6 & 5.1 & 7 & 49 & 5 & 0.28 \\
\hline AP-3 & $\mathrm{PM}_{2.5}$ & $\mu \mathrm{g} \mathrm{m}^{-3}$ & 410610119 & 3.8 & 7.4 & -60 & 69 & 7 & 0.12 \\
\hline AP-3 & $\mathrm{PM}_{2.5}$ & $\mu \mathrm{g} \mathrm{m}^{-3}$ & 530610005 & 13 & 6 & 82 & 85 & 9 & 0.27 \\
\hline AP-3 & $\mathrm{PM}_{2.5}$ & $\mu \mathrm{g} \mathrm{m}^{-3}$ & 160090010 & 4.6 & 10 & -76 & 80 & 6 & 0 \\
\hline AP-3 & $\mathrm{PM}_{2.5}$ & $\mu \mathrm{g} \mathrm{m}^{-3}$ & 410170120 & 5.5 & 5.3 & 0 & 43 & 5 & 0.36 \\
\hline AP-3 & $\mathrm{PM}_{2.5}$ & $\mu \mathrm{g} \mathrm{m}^{-3}$ & 530470009 & 2.7 & 9.2 & -101 & 103 & 9 & 0.2 \\
\hline AP-3 & $\mathrm{PM}_{2.5}$ & $\mu \mathrm{g} \mathrm{m}^{-3}$ & 530531018 & 11 & 6.9 & 39 & 57 & 8 & 0.35 \\
\hline AP-3 & $\mathrm{PM}_{2.5}$ & $\mu \mathrm{g} \mathrm{m}^{-3}$ & 530330017 & 5.7 & 5.4 & 1 & 36 & 3 & 0.43 \\
\hline AP-3 & $\mathrm{PM}_{2.5}$ & $\mu \mathrm{g} \mathrm{m}^{-3}$ & 410050004 & 10 & 5 & 46 & 53 & 2 & 0.01 \\
\hline AP-3 & $\mathrm{PM}_{2.5}$ & $\mu \mathrm{g} \mathrm{m}^{-3}$ & 410470041 & 7.8 & 6.4 & 12 & 40 & 5 & 0.47 \\
\hline AP-3 & $\mathrm{PM}_{2.5}$ & $\mu \mathrm{g} \mathrm{m}^{-3}$ & 410390060 & 7.3 & 6.5 & 9 & 41 & 7 & 0.22 \\
\hline AP-3 & $\mathrm{PM}_{2.5}$ & $\mu \mathrm{g} \mathrm{m}^{-3}$ & 530330080 & 15 & 6.2 & 76 & 78 & 12 & 0.33 \\
\hline AP-3 & $\mathrm{PM}_{2.5}$ & $\mu \mathrm{g} \mathrm{m}^{-3}$ & 410510080 & 15 & 7.5 & 61 & 66 & 11 & 0.48 \\
\hline AP-3 & $\mathrm{PM}_{2.5}$ & $\mu \mathrm{g} \mathrm{m}^{-3}$ & 160490002 & 4.4 & 4.1 & 37 & 64 & 7 & 0.51 \\
\hline AP-3 & $\mathrm{PM}_{2.5}$ & $\mu \mathrm{g} \mathrm{m}^{-3}$ & 530330057 & 15 & 10 & 42 & 52 & 9 & 0.3 \\
\hline AP-3 & $\mathrm{PM}_{2.5}$ & $\mu \mathrm{g} \mathrm{m}^{-3}$ & 530670013 & 7.1 & 5.9 & 10 & 51 & 6 & 0.38 \\
\hline AP-3 & $\mathrm{PM}_{2.5}$ & $\mu \mathrm{g} \mathrm{m}^{-3}$ & 410670004 & 9.2 & 7.3 & 20 & 45 & 6 & 0.42 \\
\hline AP-3 & $\mathrm{PM}_{2.5}$ & $\mu \mathrm{g} \mathrm{m}^{-3}$ & 530530031 & 15 & 7.4 & 60 & 65 & 11 & 0.43 \\
\hline AP-3 & $\mathrm{PM}_{2.5}$ & $\mu \mathrm{g} \mathrm{m}^{-3}$ & 160570005 & 6 & 4.4 & 49 & 68 & 5 & 0.4 \\
\hline AP-3 & $\mathrm{PM}_{2.5}$ & $\mu \mathrm{g} \mathrm{m}^{-3}$ & 160690012 & 7 & 5.7 & 31 & 49 & 5 & 0.38 \\
\hline AP-3 & $\mathrm{PM}_{2.5}$ & $\mu \mathrm{g} \mathrm{m}^{-3}$ & 410650007 & 5.1 & 6.2 & -21 & 45 & 4 & 0.25 \\
\hline AP-3 & $\mathrm{PM}_{2.5}$ & $\mu \mathrm{g} \mathrm{m}^{-3}$ & 530770016 & 5 & 6.4 & -28 & 45 & 3 & 0.33 \\
\hline AP-3 & $\mathrm{PM}_{2.5}$ & $\mu \mathrm{g} \mathrm{m}^{-3}$ & 530330024 & 13 & 7.4 & 55 & 63 & 9 & 0.39 \\
\hline AP-3 & $\mathrm{PM}_{2.5}$ & $\mu \mathrm{g} \mathrm{m}^{-3}$ & 490494001 & 5.6 & 9.2 & -43 & 60 & 7 & 0.07 \\
\hline AP-3 & $\mathrm{PM}_{2.5}$ & $\mu \mathrm{g} \mathrm{m}^{-3}$ & 530750006 & 5.2 & 4.6 & 5 & 44 & 3 & 0.24 \\
\hline AP-3 & $\mathrm{PM}_{2.5}$ & $\mu \mathrm{g} \mathrm{m}^{-3}$ & 530650002 & 4.7 & 5.1 & -19 & 45 & 3 & 0.29 \\
\hline AP-3 & $\mathrm{PM}_{2.5}$ & $\mu \mathrm{g} \mathrm{m}^{-3}$ & 410432002 & 4.9 & 7.1 & -35 & 78 & 8 & 0.01 \\
\hline AP-3 & $\mathrm{PM}_{2.5}$ & $\mu \mathrm{g} \mathrm{m}^{-3}$ & 530611007 & 9.3 & 7.7 & 22 & 50 & 6 & 0.16 \\
\hline AP-3 & $\mathrm{PM}_{2.5}$ & $\mu \mathrm{g} \mathrm{m}^{-3}$ & 490490002 & 5.5 & 6.6 & -14 & 53 & 4 & 0.11 \\
\hline AP-3 & $\mathrm{PM}_{2.5}$ & $\mu \mathrm{g} \mathrm{m}^{-3}$ & 410010004 & 3.9 & 7.5 & -68 & 73 & 5 & 0.18 \\
\hline AP-3 & $\mathrm{PM}_{2.5}$ & $\mu \mathrm{g} \mathrm{m}^{-3}$ & 410290133 & 5.9 & 9 & -33 & 67 & 8 & 0.03 \\
\hline
\end{tabular}


This is a non peer-reviewed preprint submitted to EarthArxiv.

\begin{tabular}{|c|c|c|c|c|c|c|c|c|c|}
\hline AP-3 & $\mathrm{PM}_{2.5}$ & $\mu \mathrm{g} \mathrm{m}^{-3}$ & 530750005 & 4.9 & 4.2 & 9 & 46 & 3 & 0.4 \\
\hline AP-3 & $\mathrm{PM}_{2.5}$ & $\mu \mathrm{g} \mathrm{m}^{-3}$ & 410130100 & 3.3 & 7.9 & -66 & 77 & 8 & 0.02 \\
\hline AP-3 & $\mathrm{PM}_{2.5}$ & $\mu \mathrm{g} \mathrm{m}^{-3}$ & 410190002 & 5 & 6.3 & -36 & 55 & 6 & 0.11 \\
\hline AP-3 & $\mathrm{PM}_{2.5}$ & $\mu \mathrm{g} \mathrm{m}^{-3}$ & 530630021 & 8.9 & 8.8 & -6 & 33 & 4 & 0.36 \\
\hline AP-3 & $\mathrm{PM}_{2.5}$ & $\mu \mathrm{g} \mathrm{m}^{-3}$ & 490030003 & 5.2 & 8.1 & -34 & 57 & 6 & 0.26 \\
\hline AP-3 & $\mathrm{PM}_{2.5}$ & $\mu \mathrm{g} \mathrm{m}^{-3}$ & 410590121 & 4.1 & 7.4 & -54 & 62 & 6 & 0.18 \\
\hline AP-3 & $\mathrm{PM}_{2.5}$ & $\mu \mathrm{g} \mathrm{m}^{-3}$ & 530272002 & 4.2 & 3.9 & -13 & 54 & 4 & 0.23 \\
\hline AP-3 & $\mathrm{PM}_{2.5}$ & $\mu \mathrm{g} \mathrm{m}^{-3}$ & 410250003 & 2.6 & 9.8 & -100 & 103 & 8 & 0.02 \\
\hline AP-3 & $\mathrm{PM}_{2.5}$ & $\mu \mathrm{g} \mathrm{m}^{-3}$ & 530530029 & 13 & 7.9 & 52 & 60 & 8 & 0.42 \\
\hline AP-3 & $\mathrm{PM}_{2.5}$ & $\mu \mathrm{g} \mathrm{m}^{-3}$ & 410430009 & 7.6 & 6.1 & 15 & 45 & 6 & 0.34 \\
\hline AP-3 & $\mathrm{PM}_{2.5}$ & $\mu \mathrm{g} \mathrm{m}^{-3}$ & 530610020 & 3.6 & 7.3 & -47 & 75 & 7 & 0.04 \\
\hline AP-3 & $\mathrm{PM}_{2.5}$ & $\mu \mathrm{g} \mathrm{m}^{-3}$ & 530331011 & 15 & 8.5 & 48 & 55 & 10 & 0.39 \\
\hline AP-3 & $\mathrm{PM}_{2.5}$ & $\mu \mathrm{g} \mathrm{m}^{-3}$ & 530410004 & 6.1 & 5.7 & -24 & 55 & 4 & 0.37 \\
\hline AP-3 & $\mathrm{PM}_{2.5}$ & $\mu \mathrm{g} \mathrm{m}^{-3}$ & 530251002 & 5.2 & 6.1 & -23 & 43 & 4 & 0.42 \\
\hline AP-3 & $\mathrm{PM}_{2.5}$ & $\mu \mathrm{g} \mathrm{m}^{-3}$ & 160090011 & 4.9 & 7 & -38 & 51 & 5 & 0.28 \\
\hline AP-3 & $\mathrm{PM}_{2.5}$ & $\mu \mathrm{g} \mathrm{m}^{-3}$ & 410330114 & 5.1 & 7 & -32 & 57 & 6 & 0.17 \\
\hline AP-3 & $\mathrm{PM}_{2.5}$ & $\mu \mathrm{g} \mathrm{m}^{-3}$ & 410330011 & 3.9 & 5.3 & -44 & 64 & 4 & 0.1 \\
\hline AP-3 & $\mathrm{PM}_{2.5}$ & $\mu \mathrm{g} \mathrm{m}^{-3}$ & 490570002 & 8.5 & 11 & -14 & 45 & 7 & 0.2 \\
\hline AP-3 & $\mathrm{PM}_{2.5}$ & $\mu \mathrm{g} \mathrm{m}^{-3}$ & 160790017 & 4.8 & 13 & -74 & 86 & 12 & 0.02 \\
\hline AP-3 & $\mathrm{PM}_{2.5}$ & $\mu \mathrm{g} \mathrm{m}^{-3}$ & 530370002 & 4.9 & 7.8 & -23 & 51 & 9 & 0.39 \\
\hline AP-3 & $\mathrm{PM}_{2.5}$ & $\mu \mathrm{g} \mathrm{m}^{-3}$ & 410330036 & 3.3 & 6 & -73 & 89 & 4 & 0.04 \\
\hline AP-3 & $\mathrm{PM}_{2.5}$ & $\mu \mathrm{g} \mathrm{m}^{-3}$ & 530330037 & 12 & 4.7 & 81 & 83 & 10 & 0.34 \\
\hline AP-3 & $\mathrm{PM}_{2.5}$ & $\mu \mathrm{g} \mathrm{m}^{-3}$ & 410230002 & 3.2 & 8.9 & -93 & 102 & 7 & 0 \\
\hline AP-3 & $\mathrm{PM}_{2.5}$ & $\mu \mathrm{g} \mathrm{m}^{-3}$ & 160150001 & 4 & 5.7 & -37 & 57 & 2 & 0 \\
\hline AP-3 & $\mathrm{PM}_{2.5}$ & $\mu \mathrm{g} \mathrm{m}^{-3}$ & 530090015 & 1.9 & 3.5 & -81 & 88 & 2 & 0.12 \\
\hline AP-3 & $\mathrm{PM}_{2.5}$ & $\mu \mathrm{g} \mathrm{m}^{-3}$ & 410290019 & 4.2 & 5.4 & -34 & 54 & 5 & 0.08 \\
\hline AP-3 & $\mathrm{PM}_{2.5}$ & $\mu \mathrm{g} \mathrm{m}^{-3}$ & 300490026 & 5.8 & 9 & -17 & 49 & 6 & 0.23 \\
\hline AP-3 & $\mathrm{PM}_{2.5}$ & $\mu \mathrm{g} \mathrm{m}^{-3}$ & 530050002 & 5.6 & 6.2 & -17 & 40 & 3 & 0.46 \\
\hline AP-3 & $\mathrm{PM}_{2.5}$ & $\mu \mathrm{g} \mathrm{m}^{-3}$ & 530030004 & 5.4 & 8.1 & -35 & 48 & 6 & 0.45 \\
\hline AP-3 & $\mathrm{PM}_{2.5}$ & $\mu \mathrm{g} \mathrm{m}^{-3}$ & 530310003 & 5.3 & 5.4 & -11 & 42 & 3 & 0.25 \\
\hline AP-3 & $\mathrm{PM}_{2.5}$ & $\mu \mathrm{g} \mathrm{m}^{-3}$ & 300530018 & 4.9 & 11 & -69 & 77 & 9 & 0.04 \\
\hline AP-3 & $\mathrm{PM}_{2.5}$ & $\mu \mathrm{g} \mathrm{m}^{-3}$ & 530770009 & 5.7 & 8.6 & -24 & 49 & 7 & 0.34 \\
\hline AP-3 & $\mathrm{PM}_{2.5}$ & $\mu \mathrm{g} \mathrm{m}^{-3}$ & 530130002 & 3.8 & 5.3 & -36 & 47 & 3 & 0.32 \\
\hline AP-3 & $\mathrm{PM}_{2.5}$ & $\mu \mathrm{g} \mathrm{m}^{-3}$ & 410170004 & 4.9 & 11 & -77 & 84 & 35 & 0.42 \\
\hline AP-3 & $\mathrm{PM}_{2.5}$ & $\mu \mathrm{g} \mathrm{m}^{-3}$ & 490353006 & 11 & 9.2 & 35 & 60 & 8 & 0.2 \\
\hline AP-3 & $\mathrm{PM}_{2.5}$ & $\mu \mathrm{g} \mathrm{m}^{-3}$ & 530570015 & 6.1 & 4.6 & 18 & 44 & 4 & 0.28 \\
\hline AP-3 & $\mathrm{PM}_{2.5}$ & $\mu \mathrm{g} \mathrm{m}^{-3}$ & 530730015 & 6.6 & 5.7 & 11 & 42 & 4 & 0.25 \\
\hline AP-3 & $\mathrm{PM}_{2.5}$ & $\mu \mathrm{g} \mathrm{m}^{-3}$ & 530470010 & 2.7 & 7.6 & -91 & 92 & 7 & 0.21 \\
\hline AP-3 & $\mathrm{PM}_{2.5}$ & $\mu \mathrm{g} \mathrm{m}^{-3}$ & 160270002 & 15.3 & 10 & 19 & 36 & 2 & 0.01 \\
\hline AP-3 & $\mathrm{PM}_{2.5}$ & $\mu \mathrm{g} \mathrm{m}^{-3}$ & 530750003 & 5.5 & 5.6 & -4 & 39 & 3 & 0.47 \\
\hline AP-3 & $\mathrm{PM}_{2.5}$ & $\mu \mathrm{g} \mathrm{m}^{-3}$ & 530770015 & 5.8 & 8.5 & -22 & 46 & 6 & 0.52 \\
\hline AP-3 & $\mathrm{PM}_{2.5}$ & $\mu \mathrm{g} \mathrm{m}^{-3}$ & 410392013 & 3.8 & 9.3 & -79 & 97 & 11 & 0 \\
\hline AP-3 & $\mathrm{PM}_{2.5}$ & $\mu \mathrm{g} \mathrm{m}^{-3}$ & 160590004 & 5 & 14 & -67 & 84 & 18 & 0.48 \\
\hline
\end{tabular}


This is a non peer-reviewed preprint submitted to EarthArxiv.

\begin{tabular}{|c|c|c|c|c|c|c|c|c|c|}
\hline AP-3 & $\mathrm{PM}_{2.5}$ & $\mu \mathrm{g} \mathrm{m}^{-3}$ & 410370001 & 2.5 & 8.6 & -86 & 90 & 11 & 0.02 \\
\hline AP-3 & $\mathrm{PM}_{2.5}$ & $\mu \mathrm{g} \mathrm{m}^{-3}$ & 530090013 & 1.7 & 2.3 & -47 & 65 & 2 & 0.19 \\
\hline AP-3 & $\mathrm{PM}_{2.5}$ & $\mu \mathrm{g} \mathrm{m}^{-3}$ & 530470013 & 4 & 7.6 & -61 & 65 & 5 & 0.28 \\
\hline AP-3 & $\mathrm{PM}_{2.5}$ & $\mu \mathrm{g} \mathrm{m}^{-3}$ & 530110022 & 5.3 & 4.4 & 18 & 50 & 4 & 0.17 \\
\hline AP-3 & $\mathrm{PM}_{2.5}$ & $\mu \mathrm{g} \mathrm{m}^{-3}$ & 160010010 & 23 & 14 & 34 & 48 & 6 & 0.05 \\
\hline AP-3 & $\mathrm{PM}_{2.5}$ & $\mu \mathrm{g} \mathrm{m}^{-3}$ & 410090004 & 7.4 & 5.5 & 17 & 42 & 5 & 0.42 \\
\hline AP-3 & $\mathrm{PM}_{2.5}$ & $\mu \mathrm{g} \mathrm{m}^{-3}$ & 410030013 & 5.3 & 5.2 & -16 & 48 & 5 & 0.38 \\
\hline AP-3 & $\mathrm{PM}_{2.5}$ & $\mu \mathrm{g} \mathrm{m}^{-3}$ & 530332004 & 12 & 7.9 & 44 & 60 & 8 & 0.24 \\
\hline AP-3 & $\mathrm{PM}_{2.5}$ & $\mu \mathrm{g} \mathrm{m}^{-3}$ & 530070010 & 3.3 & 6.9 & -58 & 71 & 8 & 0.42 \\
\hline AP-3 & $\mathrm{PM}_{2.5}$ & $\mu \mathrm{g} \mathrm{m}^{-3}$ & 530630047 & 8.6 & 6.8 & 26 & 42 & 5 & 0.47 \\
\hline AP-3 & $\mathrm{PM}_{2.5}$ & $\mu \mathrm{g} \mathrm{m}^{-3}$ & 410630001 & 2.6 & 6 & -78 & 81 & 5 & 0.1 \\
\hline AP-3 & $\mathrm{PM}_{2.5}$ & $\mu \mathrm{g} \mathrm{m}^{-3}$ & 410670111 & 11.9 & 5.8 & 63 & 67 & 9 & 0.51 \\
\hline AP-3 & $\mathrm{PM}_{2.5}$ & $\mu \mathrm{g} \mathrm{m}^{-3}$ & 530010003 & 4.6 & 5.2 & -19 & 43 & 3 & 0.38 \\
\hline AP-3 & $\mathrm{PM}_{2.5}$ & $\mu \mathrm{g} \mathrm{m}^{-3}$ & 530210002 & 5.5 & 5.8 & -13 & 41 & 4 & 0.39 \\
\hline AP-3 & $\mathrm{PM}_{2.5}$ & $\mu \mathrm{g} \mathrm{m}^{-3}$ & 410350004 & 5.4 & 10.3 & -43 & 70 & 11 & 0.06 \\
\hline AP-3 & $\mathrm{PM}_{2.5}$ & $\mu \mathrm{g} \mathrm{m}^{-3}$ & 530710005 & 5.5 & 6.2 & -16 & 42 & 4 & 0.42 \\
\hline AP-3 & $\mathrm{PM}_{2.5}$ & $\mu \mathrm{g} \mathrm{m}^{-3}$ & 530450007 & 5.1 & 7.3 & -50 & 62 & 3 & 0.29 \\
\hline AP-4 & $\mathrm{PM}_{2.5}$ & $\mu \mathrm{g} \mathrm{m}^{-3}$ & 530150015 & 7.1 & 6.3 & 7 & 36 & 5 & 0.35 \\
\hline AP-4 & $\mathrm{PM}_{2.5}$ & $\mu \mathrm{g} \mathrm{m}^{-3}$ & 410610119 & 3.5 & 9.1 & -70 & 73 & 9 & 0.36 \\
\hline AP-4 & $\mathrm{PM}_{2.5}$ & $\mu \mathrm{g} \mathrm{m}^{-3}$ & 530610005 & 8.7 & 6.4 & 37 & 55 & 4 & 0.18 \\
\hline AP-4 & $\mathrm{PM}_{2.5}$ & $\mu \mathrm{g} \mathrm{m}^{-3}$ & 160090010 & 2.7 & 13 & -122 & 123 & 12 & 0.17 \\
\hline AP-4 & $\mathrm{PM}_{2.5}$ & $\mu \mathrm{g} \mathrm{m}^{-3}$ & 410170120 & 8.6 & 6 & 43 & 58 & 7 & 0.13 \\
\hline AP-4 & $\mathrm{PM}_{2.5}$ & $\mu \mathrm{g} \mathrm{m}^{-3}$ & 530470009 & 2.1 & 9.4 & -120 & 121 & 12 & 0.38 \\
\hline AP-4 & $\mathrm{PM}_{2.5}$ & $\mu \mathrm{g} \mathrm{m}^{-3}$ & 530531018 & 10 & 6.5 & 43 & 59 & 8 & 0.42 \\
\hline AP-4 & $\mathrm{PM}_{2.5}$ & $\mu \mathrm{g} \mathrm{m}^{-3}$ & 530330017 & 5.7 & 5.3 & 4 & 51 & 4 & 0.13 \\
\hline AP-4 & $\mathrm{PM}_{2.5}$ & $\mu \mathrm{g} \mathrm{m}^{-3}$ & 410050004 & 10 & 5.2 & 45 & 63 & 4 & 0 \\
\hline AP-4 & $\mathrm{PM}_{2.5}$ & $\mu \mathrm{g} \mathrm{m}^{-3}$ & 410470041 & 15 & 7.2 & 67 & 70 & 12 & 0.38 \\
\hline AP-4 & $\mathrm{PM}_{2.5}$ & $\mu \mathrm{g} \mathrm{m}^{-3}$ & 410390060 & 11 & 7.9 & 34 & 48 & 9 & 0.34 \\
\hline AP-4 & $\mathrm{PM}_{2.5}$ & $\mu \mathrm{g} \mathrm{m}^{-3}$ & 530330080 & 12 & 6.4 & 49 & 59 & 9 & 0.25 \\
\hline AP-4 & $\mathrm{PM}_{2.5}$ & $\mu \mathrm{g} \mathrm{m}^{-3}$ & 410510080 & 16 & 7.5 & 65 & 69 & 14 & 0.39 \\
\hline AP-4 & $\mathrm{PM}_{2.5}$ & $\mu \mathrm{g} \mathrm{m}^{-3}$ & 160490002 & 2.1 & 7.6 & -17 & 86 & 11 & 0.15 \\
\hline AP-4 & $\mathrm{PM}_{2.5}$ & $\mu \mathrm{g} \mathrm{m}^{-3}$ & 530330057 & 14 & 10.3 & -10 & 32 & 1 & 0 \\
\hline AP-4 & $\mathrm{PM}_{2.5}$ & $\mu \mathrm{g} \mathrm{m}^{-3}$ & 530670013 & 8 & 7.2 & 6 & 39 & 5 & 0.54 \\
\hline$A P-4$ & $\mathrm{PM}_{2.5}$ & $\mu \mathrm{g} \mathrm{m}^{-3}$ & 410670004 & 14 & 7.1 & 57 & 63 & 12 & 0.42 \\
\hline$A P-4$ & $\mathrm{PM}_{2.5}$ & $\mu \mathrm{g} \mathrm{m}^{-3}$ & 530530031 & 11 & 8 & 18 & 42 & 8 & 0.47 \\
\hline AP-4 & $\mathrm{PM}_{2.5}$ & $\mu \mathrm{g} \mathrm{m}^{-3}$ & 160570005 & 4.2 & 6 & 50 & 99 & 8 & 0.02 \\
\hline AP-4 & $\mathrm{PM}_{2.5}$ & $\mu \mathrm{g} \mathrm{m}^{-3}$ & 160690012 & 4.9 & 8.3 & 7 & 69 & 11 & 0.02 \\
\hline AP-4 & $\mathrm{PM}_{2.5}$ & $\mu \mathrm{g} \mathrm{m}^{-3}$ & 410650007 & 6.3 & 6.8 & -14 & 45 & 6 & 0.16 \\
\hline AP-4 & $\mathrm{PM}_{2.5}$ & $\mu \mathrm{g} \mathrm{m}^{-3}$ & 530770016 & 4.1 & 6.3 & -51 & 69 & 6 & 0.15 \\
\hline$A P-4$ & $\mathrm{PM}_{2.5}$ & $\mu \mathrm{g} \mathrm{m}^{-3}$ & 530330024 & 9.5 & 7.8 & 17 & 42 & 6 & 0.46 \\
\hline$A P-4$ & $\mathrm{PM}_{2.5}$ & $\mu \mathrm{g} \mathrm{m}^{-3}$ & 490494001 & 7.2 & 9.5 & -5 & 56 & 11 & 0.15 \\
\hline AP-4 & $\mathrm{PM}_{2.5}$ & $\mu \mathrm{g} \mathrm{m}^{-3}$ & 530750006 & 3.5 & 5.4 & -36 & 58 & 5 & 0.08 \\
\hline AP-4 & $\mathrm{PM}_{2.5}$ & $\mu \mathrm{g} \mathrm{m}^{-3}$ & 530650002 & 2.6 & 5.9 & -74 & 88 & 6 & 0.3 \\
\hline
\end{tabular}


This is a non peer-reviewed preprint submitted to EarthArxiv.

\begin{tabular}{|c|c|c|c|c|c|c|c|c|c|}
\hline AP-4 & $\mathrm{PM}_{2.5}$ & $\mu \mathrm{g} \mathrm{m}^{-3}$ & 410432002 & 8.2 & 6.2 & 24 & 54 & 14 & 0.06 \\
\hline AP-4 & $\mathrm{PM}_{2.5}$ & $\mu \mathrm{g} \mathrm{m}^{-3}$ & 530611007 & 9.2 & 7.9 & 17 & 46 & 4 & 0.13 \\
\hline AP-4 & $\mathrm{PM}_{2.5}$ & $\mu \mathrm{g} \mathrm{m}^{-3}$ & 490490002 & 7.3 & 7.3 & 1 & 43 & 5 & 0.26 \\
\hline AP-4 & $\mathrm{PM}_{2.5}$ & $\mu g \mathrm{~m}^{-3}$ & 410010004 & 4.5 & 8 & -53 & 58 & 7 & 0.16 \\
\hline AP-4 & $\mathrm{PM}_{2.5}$ & $\mu g \mathrm{~m}^{-3}$ & 410290133 & 16 & 12 & 36 & 57 & 12 & 0.29 \\
\hline AP-4 & $\mathrm{PM}_{2.5}$ & $\mu \mathrm{g} \mathrm{m}^{-3}$ & 530750005 & 3.7 & 5.3 & -28 & 57 & 6 & 0.07 \\
\hline AP-4 & $\mathrm{PM}_{2.5}$ & $\mu g \mathrm{~m}^{-3}$ & 410130100 & 4.9 & 9.8 & -39 & 58 & 11 & 0.13 \\
\hline AP-4 & $\mathrm{PM}_{2.5}$ & $\mu g \mathrm{~m}^{-3}$ & 410190002 & 8.6 & 6.8 & 16 & 46 & 6 & 0.3 \\
\hline AP-4 & $\mathrm{PM}_{2.5}$ & $\mu \mathrm{g} \mathrm{m}^{-3}$ & 530630021 & 5.9 & 9.3 & -57 & 68 & 5 & 0.11 \\
\hline AP-4 & $\mathrm{PM}_{2.5}$ & $\mu \mathrm{g} \mathrm{m}^{-3}$ & 490030003 & 3.6 & 6.9 & -38 & 59 & 7 & 0.44 \\
\hline AP-4 & $\mathrm{PM}_{2.5}$ & $\mu \mathrm{g} \mathrm{m}^{-3}$ & 410590121 & 7.6 & 7.3 & 3 & 48 & 6 & 0.28 \\
\hline AP-4 & $\mathrm{PM}_{2.5}$ & $\mu \mathrm{g} \mathrm{m}^{-3}$ & 530272002 & 3.8 & 5.7 & -44 & 52 & 3 & 0.27 \\
\hline AP-4 & $\mathrm{PM}_{2.5}$ & $\mu \mathrm{g} \mathrm{m}^{-3}$ & 410250003 & 2.6 & 9.2 & -99 & 100 & 9 & 0.39 \\
\hline AP-4 & $\mathrm{PM}_{2.5}$ & $\mu g \mathrm{~m}^{-3}$ & 530530029 & 9.1 & 7.9 & 11 & 37 & 6 & 0.44 \\
\hline AP-4 & $\mathrm{PM}_{2.5}$ & $\mu g \mathrm{~m}^{-3}$ & 410430009 & 12 & 7.1 & 51 & 58 & 10 & 0.32 \\
\hline AP-4 & $\mathrm{PM}_{2.5}$ & $\mu \mathrm{g} \mathrm{m}^{-3}$ & 530610020 & 3.1 & 6.5 & -47 & 64 & 5 & 0.08 \\
\hline AP-4 & $\mathrm{PM}_{2.5}$ & $\mu g \mathrm{~m}^{-3}$ & 530331011 & 14 & 9.4 & 28 & 40 & 9 & 0.45 \\
\hline AP-4 & $\mathrm{PM}_{2.5}$ & $\mu g \mathrm{~m}^{-3}$ & 530410004 & 6.6 & 6.6 & -16 & 44 & 4 & 0.43 \\
\hline AP-4 & $\mathrm{PM}_{2.5}$ & $\mu g \mathrm{~m}^{-3}$ & 530251002 & 4.3 & 6.8 & -48 & 60 & 5 & 0.2 \\
\hline AP-4 & $\mathrm{PM}_{2.5}$ & $\mu \mathrm{g} \mathrm{m}^{-3}$ & 160090011 & 2.8 & 7.8 & -86 & 90 & 8 & 0.07 \\
\hline AP-4 & $\mathrm{PM}_{2.5}$ & $\mu g \mathrm{~m}^{-3}$ & 410330114 & 13 & 8.9 & 34 & 52 & 24 & 0.35 \\
\hline AP-4 & $\mathrm{PM}_{2.5}$ & $\mu g \mathrm{~m}^{-3}$ & 410330011 & 5.6 & 7.1 & -31 & 49 & 13 & 0.31 \\
\hline AP-4 & $\mathrm{PM}_{2.5}$ & $\mu \mathrm{g} \mathrm{m}^{-3}$ & 490570002 & 9.2 & 12 & -24 & 44 & 8 & 0.29 \\
\hline AP-4 & $\mathrm{PM}_{2.5}$ & $\mu \mathrm{g} \mathrm{m}^{-3}$ & 160790017 & 2.4 & 14 & -126 & 128 & 16 & 0.21 \\
\hline AP-4 & $\mathrm{PM}_{2.5}$ & $\mu \mathrm{g} \mathrm{m}^{-3}$ & 530370002 & 3.5 & 6.5 & -50 & 62 & 6 & 0.32 \\
\hline AP-4 & $\mathrm{PM}_{2.5}$ & $\mu \mathrm{g} \mathrm{m}^{-3}$ & 410330036 & 5.7 & 9.1 & -39 & 51 & 14 & 0.24 \\
\hline AP-4 & $\mathrm{PM}_{2.5}$ & $\mu \mathrm{g} \mathrm{m}^{-3}$ & 530330037 & 9.1 & 5.2 & 46 & 54 & 6 & 0.29 \\
\hline AP-4 & $\mathrm{PM}_{2.5}$ & $\mu g \mathrm{~m}^{-3}$ & 410230002 & 2.2 & 10 & -113 & 113 & 11 & 0.25 \\
\hline AP-4 & $\mathrm{PM}_{2.5}$ & $\mu g \mathrm{~m}^{-3}$ & 160150001 & 2.5 & 5.7 & -63 & 84 & 4 & 0 \\
\hline AP-4 & $\mathrm{PM}_{2.5}$ & $\mu \mathrm{g} \mathrm{m}^{-3}$ & 530090015 & 2.4 & 4.1 & -59 & 65 & 3 & 0.06 \\
\hline AP-4 & $\mathrm{PM}_{2.5}$ & $\mu g \mathrm{~m}^{-3}$ & 410290019 & 5.7 & 8.1 & -9 & 40 & 15 & 0.13 \\
\hline AP-4 & $\mathrm{PM}_{2.5}$ & $\mu g \mathrm{~m}^{-3}$ & 300490026 & 3.1 & 8.3 & -79 & 83 & 9 & 0.21 \\
\hline AP-4 & $\mathrm{PM}_{2.5}$ & $\mu \mathrm{g} \mathrm{m}^{-3}$ & 530050002 & 5 & 6.5 & -35 & 54 & 5 & 0.29 \\
\hline AP-4 & $\mathrm{PM}_{2.5}$ & $\mu \mathrm{g} \mathrm{m}^{-3}$ & 530030004 & 3.3 & 8.4 & -81 & 83 & 7 & 0.16 \\
\hline AP-4 & $\mathrm{PM}_{2.5}$ & $\mu g \mathrm{~m}^{-3}$ & 530310003 & 5.4 & 5.9 & -21 & 41 & 5 & 0.16 \\
\hline AP-4 & $\mathrm{PM}_{2.5}$ & $\mu g \mathrm{~m}^{-3}$ & 300530018 & 3.8 & 12 & -78 & 86 & 13 & 0.32 \\
\hline AP-4 & $\mathrm{PM}_{2.5}$ & $\mu \mathrm{g} \mathrm{m}^{-3}$ & 530770009 & 5.5 & 9.5 & -59 & 69 & 7 & 0.37 \\
\hline AP-4 & $\mathrm{PM}_{2.5}$ & $\mu g \mathrm{~m}^{-3}$ & 530130002 & 4 & 5.1 & -24 & 46 & 3 & 0.24 \\
\hline AP-4 & $\mathrm{PM}_{2.5}$ & $\mu g \mathrm{~m}^{-3}$ & 410170004 & 4.8 & 5.2 & -4 & 49 & 5 & 0.05 \\
\hline AP-4 & $\mathrm{PM}_{2.5}$ & $\mu \mathrm{g} \mathrm{m}^{-3}$ & 490353006 & 13 & 8.5 & 52 & 62 & 9 & 0.47 \\
\hline AP-4 & $\mathrm{PM}_{2.5}$ & $\mu \mathrm{g} \mathrm{m}^{-3}$ & 530570015 & 5.4 & 4.6 & 9 & 40 & 4 & 0.21 \\
\hline AP-4 & $\mathrm{PM}_{2.5}$ & $\mu g \mathrm{~m}^{-3}$ & 530730015 & 5.6 & 7 & -23 & 46 & 4 & 0.25 \\
\hline AP-4 & $\mathrm{PM}_{2.5}$ & $\mu \mathrm{g} \mathrm{m}^{-3}$ & 530470010 & 1.8 & 6.8 & -116 & 116 & 6 & 0.22 \\
\hline
\end{tabular}


This is a non peer-reviewed preprint submitted to EarthArxiv.

\begin{tabular}{|c|c|c|c|c|c|c|c|c|c|}
\hline AP-4 & $\mathrm{PM}_{2.5}$ & $\mu \mathrm{g} \mathrm{m}^{-3}$ & 160270002 & 9.5 & 8.3 & 9 & 58 & 5 & 0 \\
\hline AP-4 & $\mathrm{PM}_{2.5}$ & $\mu \mathrm{g} \mathrm{m}^{-3}$ & 530750003 & 3.8 & 5.5 & -32 & 52 & 4 & 0.05 \\
\hline AP-4 & $\mathrm{PM}_{2.5}$ & $\mu \mathrm{g} \mathrm{m}^{-3}$ & 530770015 & 5.6 & 11 & -53 & 65 & 10 & 0.3 \\
\hline AP-4 & $\mathrm{PM}_{2.5}$ & $\mu \mathrm{g} \mathrm{m}^{-3}$ & 410392013 & 6 & 9.6 & -43 & 61 & 15 & 0.05 \\
\hline AP-4 & $\mathrm{PM}_{2.5}$ & $\mu \mathrm{g} \mathrm{m}^{-3}$ & 160590004 & 2.4 & 13 & -121 & 122 & 17 & 0.16 \\
\hline AP-4 & $\mathrm{PM}_{2.5}$ & $\mu \mathrm{g} \mathrm{m}^{-3}$ & 410370001 & 1.9 & 10 & -110 & 110 & 16 & 0.22 \\
\hline AP-4 & $\mathrm{PM}_{2.5}$ & $\mu \mathrm{g} \mathrm{m}^{-3}$ & 530090013 & 2.3 & 2.3 & -4 & 43 & 2 & 0.07 \\
\hline AP-4 & $\mathrm{PM}_{2.5}$ & $\mu \mathrm{g} \mathrm{m}^{-3}$ & 530470013 & 2.7 & 13 & -111 & 112 & 27 & 0.55 \\
\hline AP-4 & $\mathrm{PM}_{2.5}$ & $\mu \mathrm{g} \mathrm{m}^{-3}$ & 530110022 & 4.5 & 6 & -22 & 50 & 5 & 0.09 \\
\hline AP-4 & $\mathrm{PM}_{2.5}$ & $\mu \mathrm{g} \mathrm{m}^{-3}$ & 160010010 & 7.4 & 6.7 & 1 & 53 & 4 & 0.01 \\
\hline AP-4 & $\mathrm{PM}_{2.5}$ & $\mu \mathrm{g} \mathrm{m}^{-3}$ & 410090004 & 8.3 & 5.7 & 29 & 44 & 6 & 0.33 \\
\hline AP-4 & $\mathrm{PM}_{2.5}$ & $\mu \mathrm{g} \mathrm{m}^{-3}$ & 410030013 & 9 & 5.8 & 42 & 52 & 7 & 0.36 \\
\hline AP-4 & $\mathrm{PM}_{2.5}$ & $\mu \mathrm{g} \mathrm{m}^{-3}$ & 530332004 & 9.8 & 6.8 & 35 & 53 & 7 & 0.38 \\
\hline AP-4 & $\mathrm{PM}_{2.5}$ & $\mu \mathrm{g} \mathrm{m}^{-3}$ & 530070010 & 2.9 & 8.4 & -93 & 94 & 8 & 0.26 \\
\hline AP-4 & $\mathrm{PM}_{2.5}$ & $\mu \mathrm{g} \mathrm{m}^{-3}$ & 530630047 & 6.6 & 8 & -14 & 41 & 6 & 0.21 \\
\hline AP-4 & $\mathrm{PM}_{2.5}$ & $\mu \mathrm{g} \mathrm{m}^{-3}$ & 410630001 & 2.7 & 6.9 & -69 & 71 & 8 & 0.2 \\
\hline AP-4 & $\mathrm{PM}_{2.5}$ & $\mu \mathrm{g} \mathrm{m}^{-3}$ & 410670111 & 15 & 6 & 79 & 82 & 13 & 0.39 \\
\hline AP-4 & $\mathrm{PM}_{2.5}$ & $\mu \mathrm{g} \mathrm{m}^{-3}$ & 530010003 & 3.9 & 5.3 & -27 & 53 & 5 & 0.05 \\
\hline AP-4 & $\mathrm{PM}_{2.5}$ & $\mu \mathrm{g} \mathrm{m}^{-3}$ & 530210002 & 4.7 & 6.3 & -36 & 57 & 5 & 0.19 \\
\hline AP-4 & $\mathrm{PM}_{2.5}$ & $\mu \mathrm{g} \mathrm{m}^{-3}$ & 410350004 & 5.9 & 11 & -36 & 55 & 11 & 0.28 \\
\hline AP-4 & $\mathrm{PM}_{2.5}$ & $\mu \mathrm{g} \mathrm{m}^{-3}$ & 530710005 & 6 & 6 & -2 & 50 & 5 & 0.2 \\
\hline AP-4 & $\mathrm{PM}_{2.5}$ & $\mu \mathrm{g} \mathrm{m}^{-3}$ & 530450007 & 5.3 & 6.5 & -30 & 48 & 4 & 0.41 \\
\hline AP-5 & $\mathrm{PM}_{2.5}$ & $\mu \mathrm{g} \mathrm{m}^{-3}$ & 530150015 & 6 & 5.5 & -9 & 38 & 4 & 0.22 \\
\hline AP-5 & $\mathrm{PM}_{2.5}$ & $\mu \mathrm{g} \mathrm{m}^{-3}$ & 410610119 & 2.7 & 5.9 & -72 & 74 & 4 & 0.37 \\
\hline AP-5 & $\mathrm{PM}_{2.5}$ & $\mu \mathrm{g} \mathrm{m}^{-3}$ & 530610005 & 9.2 & 4.7 & 60 & 77 & 8 & 0.22 \\
\hline AP-5 & $\mathrm{PM}_{2.5}$ & $\mu \mathrm{g} \mathrm{m}^{-3}$ & 160090010 & 4.2 & 12 & -107 & 111 & 12 & 0.56 \\
\hline AP-5 & $\mathrm{PM}_{2.5}$ & $\mu \mathrm{g} \mathrm{m}^{-3}$ & 410170120 & 8.1 & 7.3 & 26 & 43 & 6 & 0.73 \\
\hline AP-5 & $\mathrm{PM}_{2.5}$ & $\mu \mathrm{g} \mathrm{m}^{-3}$ & 530470009 & 3.5 & 9.6 & -122 & 124 & 11 & 0.26 \\
\hline AP-5 & $\mathrm{PM}_{2.5}$ & $\mu \mathrm{g} \mathrm{m}^{-3}$ & 530531018 & 8.9 & 5.6 & 35 & 60 & 9 & 0.15 \\
\hline AP-5 & $\mathrm{PM}_{2.5}$ & $\mu \mathrm{g} \mathrm{m}^{-3}$ & 530330017 & 4.4 & 4 & 10 & 60 & 8 & 0.46 \\
\hline AP-5 & $\mathrm{PM}_{2.5}$ & $\mu \mathrm{g} \mathrm{m}^{-3}$ & 410470041 & 8.7 & 5.8 & 28 & 46 & 5 & 0.3 \\
\hline AP-5 & $\mathrm{PM}_{2.5}$ & $\mu \mathrm{g} \mathrm{m}^{-3}$ & 410390060 & 9 & 6.5 & 17 & 55 & 7 & 0.31 \\
\hline AP-5 & $\mathrm{PM}_{2.5}$ & $\mu \mathrm{g} \mathrm{m}^{-3}$ & 530330080 & 11 & 5.9 & 48 & 60 & 9 & 0.16 \\
\hline AP-5 & $\mathrm{PM}_{2.5}$ & $\mu \mathrm{g} \mathrm{m}^{-3}$ & 410510080 & 9.5 & 6.2 & 36 & 49 & 6 & 0.24 \\
\hline AP-5 & $\mathrm{PM}_{2.5}$ & $\mu \mathrm{g} \mathrm{m}^{-3}$ & 160490002 & 3.5 & 5.7 & -71 & 85 & 5 & 0.77 \\
\hline AP-5 & $\mathrm{PM}_{2.5}$ & $\mu \mathrm{g} \mathrm{m}^{-3}$ & 530330057 & 11 & 7.8 & 16 & 49 & 7 & 0.18 \\
\hline AP-5 & $\mathrm{PM}_{2.5}$ & $\mu \mathrm{g} \mathrm{m}^{-3}$ & 530670013 & 8.2 & 5.6 & 11 & 52 & 6 & 0.23 \\
\hline AP-5 & $\mathrm{PM}_{2.5}$ & $\mu \mathrm{g} \mathrm{m}^{-3}$ & 410670004 & 9.2 & 6.5 & 25 & 43 & 7 & 0.3 \\
\hline AP-5 & $\mathrm{PM}_{2.5}$ & $\mu \mathrm{g} \mathrm{m}^{-3}$ & 530530031 & 9 & 6.5 & 8 & 52 & 7 & 0.2 \\
\hline AP-5 & $\mathrm{PM}_{2.5}$ & $\mu \mathrm{g} \mathrm{m}^{-3}$ & 160570005 & 5.6 & 4.3 & 37 & 83 & 7 & 0.79 \\
\hline AP-5 & $\mathrm{PM}_{2.5}$ & $\mu \mathrm{g} \mathrm{m}^{-3}$ & 160690012 & 6.8 & 8.1 & -6 & 61 & 8 & 0.72 \\
\hline AP-5 & $\mathrm{PM}_{2.5}$ & $\mu \mathrm{g} \mathrm{m}^{-3}$ & 410650007 & 6 & 8.3 & -39 & 55 & 8 & 0.54 \\
\hline AP-5 & $\mathrm{PM}_{2.5}$ & $\mu \mathrm{g} \mathrm{m}^{-3}$ & 530770016 & 4.8 & 5.4 & -36 & 72 & 8 & 0.64 \\
\hline
\end{tabular}


This is a non peer-reviewed preprint submitted to EarthArxiv.

\begin{tabular}{|c|c|c|c|c|c|c|c|c|c|}
\hline AP-5 & $\mathrm{PM}_{2.5}$ & $\mu \mathrm{g} \mathrm{m}^{-3}$ & 530330024 & 9.8 & 6.4 & 68 & 71 & 2 & 0.06 \\
\hline AP-5 & $\mathrm{PM}_{2.5}$ & $\mu \mathrm{g} \mathrm{m}^{-3}$ & 490494001 & 7.3 & 6.4 & -17 & 57 & 23 & 0.02 \\
\hline AP-5 & $\mathrm{PM}_{2.5}$ & $\mu \mathrm{g} \mathrm{m}^{-3}$ & 530750006 & 3.9 & 5.3 & -61 & 75 & 10 & 0.75 \\
\hline AP-5 & $\mathrm{PM}_{2.5}$ & $\mu \mathrm{g} \mathrm{m}^{-3}$ & 530650002 & 3.5 & 5.9 & -83 & 87 & 9 & 0.61 \\
\hline AP-5 & $\mathrm{PM}_{2.5}$ & $\mu \mathrm{g} \mathrm{m}^{-3}$ & 410432002 & 4.9 & 7.1 & -53 & 64 & 7 & 0.32 \\
\hline AP-5 & $\mathrm{PM}_{2.5}$ & $\mu \mathrm{g} \mathrm{m}^{-3}$ & 530611007 & 8.4 & 6.8 & 10 & 54 & 6 & 0.22 \\
\hline AP-5 & $\mathrm{PM}_{2.5}$ & $\mu \mathrm{g} \mathrm{m}^{-3}$ & 490490002 & 4.8 & 5.4 & 6 & 63 & 4 & 0.23 \\
\hline AP-5 & $\mathrm{PM}_{2.5}$ & $\mu \mathrm{g} \mathrm{m}^{-3}$ & 410010004 & 4.2 & 7.3 & -63 & 67 & 4 & 0.55 \\
\hline AP-5 & $\mathrm{PM}_{2.5}$ & $\mu \mathrm{g} \mathrm{m}^{-3}$ & 410290133 & 10 & 10 & 15 & 47 & 11 & 0.66 \\
\hline AP-5 & $\mathrm{PM}_{2.5}$ & $\mu \mathrm{g} \mathrm{m}^{-3}$ & 530750005 & 4 & 4.8 & -46 & 67 & 10 & 0.75 \\
\hline AP-5 & $\mathrm{PM}_{2.5}$ & $\mu \mathrm{g} \mathrm{m}^{-3}$ & 410130100 & 5.2 & 9.1 & -54 & 59 & 7 & 0.57 \\
\hline AP-5 & $\mathrm{PM}_{2.5}$ & $\mu \mathrm{g} \mathrm{m}^{-3}$ & 410190002 & 5.7 & 6.8 & -35 & 48 & 5 & 0.26 \\
\hline AP-5 & $\mathrm{PM}_{2.5}$ & $\mu \mathrm{g} \mathrm{m}^{-3}$ & 530630021 & 7.8 & 8.6 & -21 & 57 & 9 & 0.74 \\
\hline AP-5 & $\mathrm{PM}_{2.5}$ & $\mu \mathrm{g} \mathrm{m}^{-3}$ & 490030003 & 3.4 & 7.9 & -94 & 98 & 6 & 0.22 \\
\hline AP-5 & $\mathrm{PM}_{2.5}$ & $\mu \mathrm{g} \mathrm{m}^{-3}$ & 410590121 & 5.8 & 7.2 & -24 & 43 & 6 & 0.73 \\
\hline AP-5 & $\mathrm{PM}_{2.5}$ & $\mu \mathrm{g} \mathrm{m}^{-3}$ & 530272002 & 3.1 & 5.1 & -64 & 69 & 4 & 0.1 \\
\hline AP-5 & $\mathrm{PM}_{2.5}$ & $\mu \mathrm{g} \mathrm{m}^{-3}$ & 410250003 & 3 & 9.2 & -105 & 107 & 8 & 0.28 \\
\hline AP-5 & $\mathrm{PM}_{2.5}$ & $\mu \mathrm{g} \mathrm{m}^{-3}$ & 530530029 & 8.3 & 6.4 & 12 & 44 & 6 & 0.32 \\
\hline AP-5 & $\mathrm{PM}_{2.5}$ & $\mu \mathrm{g} \mathrm{m}^{-3}$ & 410430009 & 8.4 & 6.1 & 21 & 44 & 6 & 0.25 \\
\hline AP-5 & $\mathrm{PM}_{2.5}$ & $\mu \mathrm{g} \mathrm{m}^{-3}$ & 530610020 & 3.2 & 6.5 & -40 & 81 & 9 & 0.17 \\
\hline AP-5 & $\mathrm{PM}_{2.5}$ & $\mu \mathrm{g} \mathrm{m}^{-3}$ & 530331011 & 9.7 & 8.3 & -8 & 46 & 7 & 0.15 \\
\hline AP-5 & $\mathrm{PM}_{2.5}$ & $\mu \mathrm{g} \mathrm{m}^{-3}$ & 530410004 & 5.5 & 5.7 & -33 & 52 & 5 & 0.16 \\
\hline AP-5 & $\mathrm{PM}_{2.5}$ & $\mu \mathrm{g} \mathrm{m}^{-3}$ & 530251002 & 5 & 6.2 & -47 & 65 & 10 & 0.61 \\
\hline AP-5 & $\mathrm{PM}_{2.5}$ & $\mu \mathrm{g} \mathrm{m}^{-3}$ & 160090011 & 3.8 & 7.8 & -98 & 106 & 5 & 0 \\
\hline AP-5 & $\mathrm{PM}_{2.5}$ & $\mu \mathrm{g} \mathrm{m}^{-3}$ & 410330114 & 9.2 & 9.4 & 10 & 53 & 10 & 0.38 \\
\hline AP-5 & $\mathrm{PM}_{2.5}$ & $\mu \mathrm{g} \mathrm{m}^{-3}$ & 410330011 & 4.6 & 8.3 & -86 & 89 & 10 & 0.55 \\
\hline AP-5 & $\mathrm{PM}_{2.5}$ & $\mu \mathrm{g} \mathrm{m}^{-3}$ & 490570002 & 5.8 & 7.5 & -42 & 64 & 6 & 0.1 \\
\hline AP-5 & $\mathrm{PM}_{2.5}$ & $\mu \mathrm{g} \mathrm{m}^{-3}$ & 160790017 & 3.9 & 13 & -116 & 119 & 12 & 0.61 \\
\hline AP-5 & $\mathrm{PM}_{2.5}$ & $\mu \mathrm{g} \mathrm{m}^{-3}$ & 530370002 & 5 & 7.6 & -47 & 70 & 7 & 0.67 \\
\hline AP-5 & $\mathrm{PM}_{2.5}$ & $\mu \mathrm{g} \mathrm{m}^{-3}$ & 410330036 & 7 & 9.3 & -101 & 103 & 8 & 0.11 \\
\hline AP-5 & $\mathrm{PM}_{2.5}$ & $\mu \mathrm{g} \mathrm{m}^{-3}$ & 530330037 & 10 & 3.5 & 84 & 86 & 7 & 0.08 \\
\hline AP-5 & $\mathrm{PM}_{2.5}$ & $\mu \mathrm{g} \mathrm{m}^{-3}$ & 410230002 & 2.6 & 8.8 & -117 & 119 & 8 & 0.36 \\
\hline AP-5 & $\mathrm{PM}_{2.5}$ & $\mu \mathrm{g} \mathrm{m}^{-3}$ & 160150001 & 2.8 & 7.1 & -103 & 117 & 7 & 0.03 \\
\hline AP-5 & $\mathrm{PM}_{2.5}$ & $\mu \mathrm{g} \mathrm{m}^{-3}$ & 530090015 & 2.3 & 3.7 & -58 & 67 & 3 & 0.03 \\
\hline AP-5 & $\mathrm{PM}_{2.5}$ & $\mu \mathrm{g} \mathrm{m}^{-3}$ & 410290019 & 5.5 & 7.4 & -69 & 72 & 6 & 0.43 \\
\hline AP-5 & $\mathrm{PM}_{2.5}$ & $\mu \mathrm{g} \mathrm{m}^{-3}$ & 300490026 & 4.3 & 9.1 & -68 & 76 & 9 & 0.36 \\
\hline AP-5 & $\mathrm{PM}_{2.5}$ & $\mu \mathrm{g} \mathrm{m}^{-3}$ & 530050002 & 5.9 & 6.6 & -38 & 57 & 10 & 0.66 \\
\hline AP-5 & $\mathrm{PM}_{2.5}$ & $\mu \mathrm{g} \mathrm{m}^{-3}$ & 530030004 & 4.4 & 8.7 & -83 & 87 & 9 & 0.75 \\
\hline AP-5 & $\mathrm{PM}_{2.5}$ & $\mu \mathrm{g} \mathrm{m}^{-3}$ & 530310003 & 4.5 & 5.1 & -35 & 53 & 3 & 0.25 \\
\hline AP-5 & $\mathrm{PM}_{2.5}$ & $\mu \mathrm{g} \mathrm{m}^{-3}$ & 300530018 & 5.5 & 12 & -91 & 95 & 13 & 0.44 \\
\hline AP-5 & $\mathrm{PM}_{2.5}$ & $\mu \mathrm{g} \mathrm{m}^{-3}$ & 530770009 & 7.4 & 8.7 & 14 & 93 & 7 & 0.71 \\
\hline AP-5 & $\mathrm{PM}_{2.5}$ & $\mu \mathrm{g} \mathrm{m}^{-3}$ & 530130002 & 3.8 & 5.7 & -54 & 72 & 8 & 0.62 \\
\hline AP-5 & $\mathrm{PM}_{2.5}$ & $\mu \mathrm{g} \mathrm{m}^{-3}$ & 410170004 & 4.8 & 10 & -60 & 71 & 17 & 0.52 \\
\hline
\end{tabular}


This is a non peer-reviewed preprint submitted to EarthArxiv.

\begin{tabular}{|c|c|c|c|c|c|c|c|c|c|}
\hline AP-5 & $\mathrm{PM}_{2.5}$ & $\mu \mathrm{g} \mathrm{m}^{-3}$ & 490353006 & 8.9 & 8 & -7 & 52 & 8 & 0.24 \\
\hline AP-5 & $\mathrm{PM}_{2.5}$ & $\mu g \mathrm{~m}^{-3}$ & 530570015 & 5.2 & 3.2 & 39 & 51 & 4 & 0.19 \\
\hline AP-5 & $\mathrm{PM}_{2.5}$ & $\mu g \mathrm{~m}^{-3}$ & 530730015 & 5.8 & 5.1 & 20 & 46 & 5 & 0.27 \\
\hline AP-5 & $\mathrm{PM}_{2.5}$ & $\mu \mathrm{g} \mathrm{m}^{-3}$ & 530470010 & 3.4 & 7.7 & -109 & 114 & 9 & 0.34 \\
\hline AP-5 & $\mathrm{PM}_{2.5}$ & $\mu \mathrm{g} \mathrm{m}^{-3}$ & 160270002 & 13 & 9.7 & 17 & 56 & 9 & 0.4 \\
\hline AP-5 & $\mathrm{PM}_{2.5}$ & $\mu \mathrm{g} \mathrm{m}^{-3}$ & 530750003 & 4.3 & 4.6 & -25 & 56 & 8 & 0.86 \\
\hline AP-5 & $\mathrm{PM}_{2.5}$ & $\mu g \mathrm{~m}^{-3}$ & 530770015 & 6.3 & 10.8 & -71 & 77 & 9 & 0.64 \\
\hline AP-5 & $\mathrm{PM}_{2.5}$ & $\mu \mathrm{g} \mathrm{m}^{-3}$ & 410392013 & 3.5 & 8.9 & -100 & 102 & 9 & 0.6 \\
\hline AP-5 & $\mathrm{PM}_{2.5}$ & $\mu g \mathrm{~m}^{-3}$ & 160590004 & 2.8 & 12 & -121 & 134 & 14 & 0.22 \\
\hline AP-5 & $\mathrm{PM}_{2.5}$ & $\mu \mathrm{g} \mathrm{m}^{-3}$ & 410370001 & 2.6 & 7.8 & -108 & 109 & 8 & 0.07 \\
\hline AP-5 & $\mathrm{PM}_{2.5}$ & $\mu \mathrm{g} \mathrm{m}^{-3}$ & 530090013 & 2.2 & 2.6 & -3 & 45 & 6 & 0.02 \\
\hline AP-5 & $\mathrm{PM}_{2.5}$ & $\mu \mathrm{g} \mathrm{m}^{-3}$ & 530470013 & 3.9 & 8.9 & -83 & 101 & 10 & 0.34 \\
\hline AP-5 & $\mathrm{PM}_{2.5}$ & $\mu \mathrm{g} \mathrm{m}^{-3}$ & 530110022 & 3.5 & 5 & -44 & 61 & 6 & 0.28 \\
\hline AP-5 & $\mathrm{PM}_{2.5}$ & $\mu \mathrm{g} \mathrm{m}^{-3}$ & 160010010 & 11 & 7.4 & 35 & 65 & 7 & 0.47 \\
\hline AP-5 & $\mathrm{PM}_{2.5}$ & $\mu \mathrm{g} \mathrm{m}^{-3}$ & 410090004 & 6.5 & 5.1 & 3 & 49 & 5 & 0.17 \\
\hline AP-5 & $\mathrm{PM}_{2.5}$ & $\mu g \mathrm{~m}^{-3}$ & 410030013 & 7.1 & 5.5 & 20 & 48 & 4 & 0.18 \\
\hline AP-5 & $\mathrm{PM}_{2.5}$ & $\mu \mathrm{g} \mathrm{m}^{-3}$ & 530332004 & 8.3 & 6.3 & 19 & 54 & 6 & 0.25 \\
\hline AP-5 & $\mathrm{PM}_{2.5}$ & $\mu \mathrm{g} \mathrm{m}^{-3}$ & 530070010 & 3.6 & 5.9 & -74 & 80 & 5 & 0.14 \\
\hline AP-5 & $\mathrm{PM}_{2.5}$ & $\mu \mathrm{g} \mathrm{m}^{-3}$ & 530630047 & 8.2 & 7.4 & 0 & 48 & 9 & 0.74 \\
\hline AP-5 & $\mathrm{PM}_{2.5}$ & $\mu \mathrm{g} \mathrm{m}^{-3}$ & 410630001 & 2.9 & 6.8 & -86 & 89 & 5 & 0.58 \\
\hline AP-5 & $\mathrm{PM}_{2.5}$ & $\mu \mathrm{g} \mathrm{m}^{-3}$ & 410670111 & 10 & 5.3 & 54 & 62 & 8 & 0.22 \\
\hline AP-5 & $\mathrm{PM}_{2.5}$ & $\mu \mathrm{g} \mathrm{m}^{-3}$ & 530010003 & 4.3 & 4.8 & -38 & 59 & 10 & 0.74 \\
\hline AP-5 & $\mathrm{PM}_{2.5}$ & $\mu \mathrm{g} \mathrm{m}^{-3}$ & 530210002 & 5.1 & 5.6 & -43 & 65 & 11 & 0.67 \\
\hline AP-5 & $\mathrm{PM}_{2.5}$ & $\mu g \mathrm{~m}^{-3}$ & 410350004 & 6.8 & 11 & -57 & 63 & 7 & 0.54 \\
\hline AP-5 & $\mathrm{PM}_{2.5}$ & $\mu \mathrm{g} \mathrm{m}^{-3}$ & 530710005 & 6 & 6.3 & -16 & 51 & 8 & 0.71 \\
\hline AP-5 & $\mathrm{PM}_{2.5}$ & $\mu \mathrm{g} \mathrm{m}^{-3}$ & 530450007 & 4.2 & 5.7 & -48 & 56 & 4 & 0.26 \\
\hline
\end{tabular}




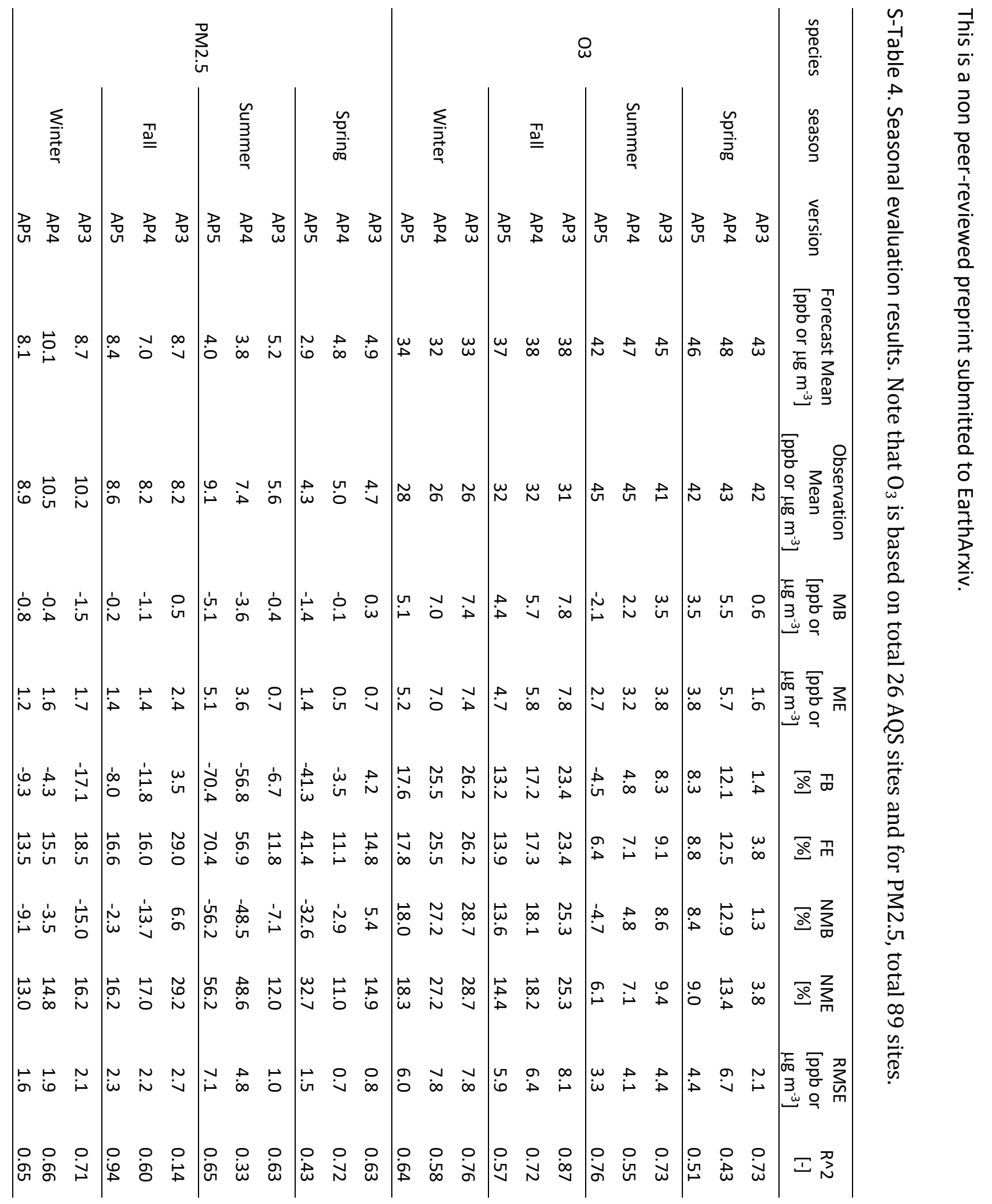




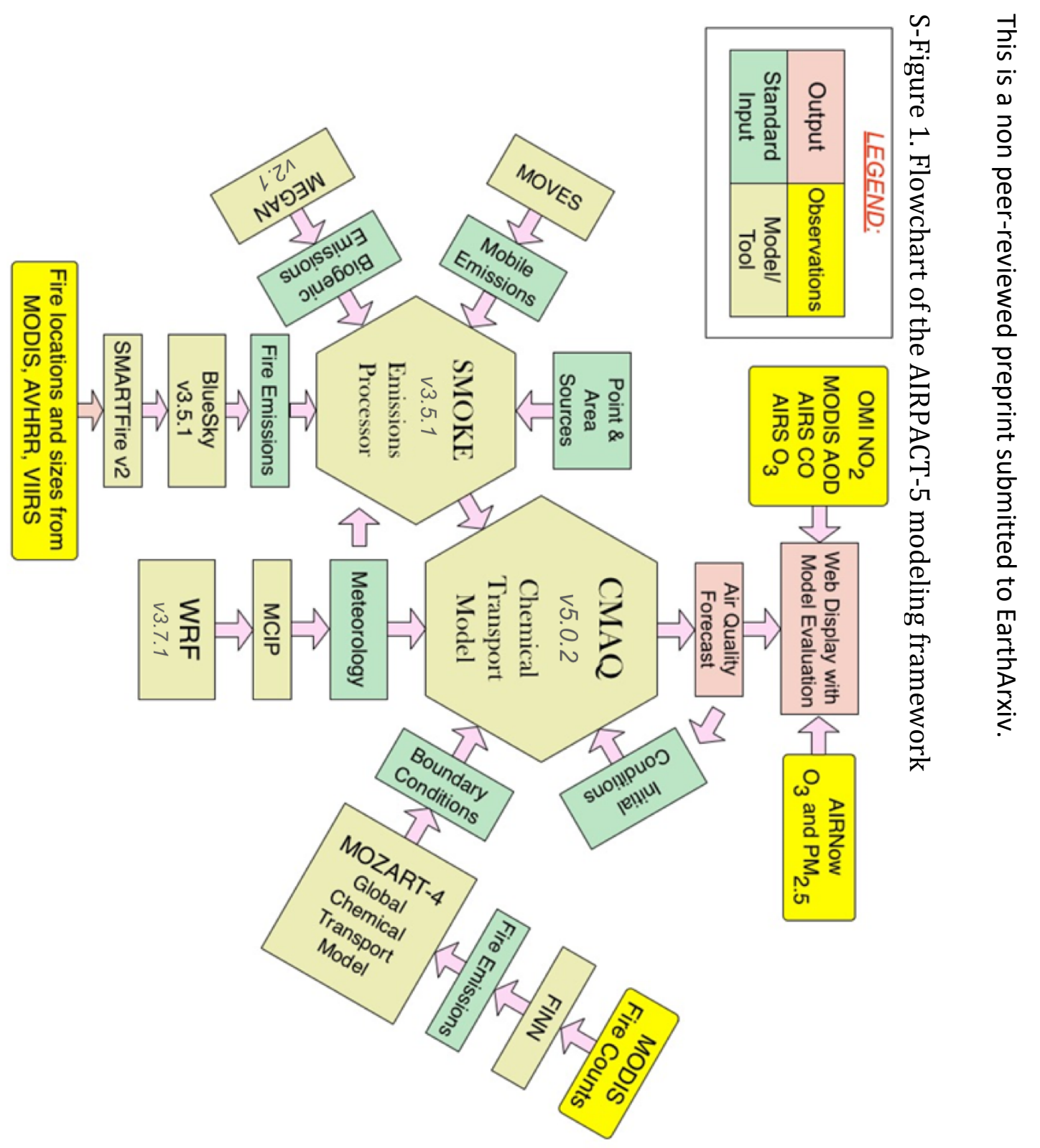




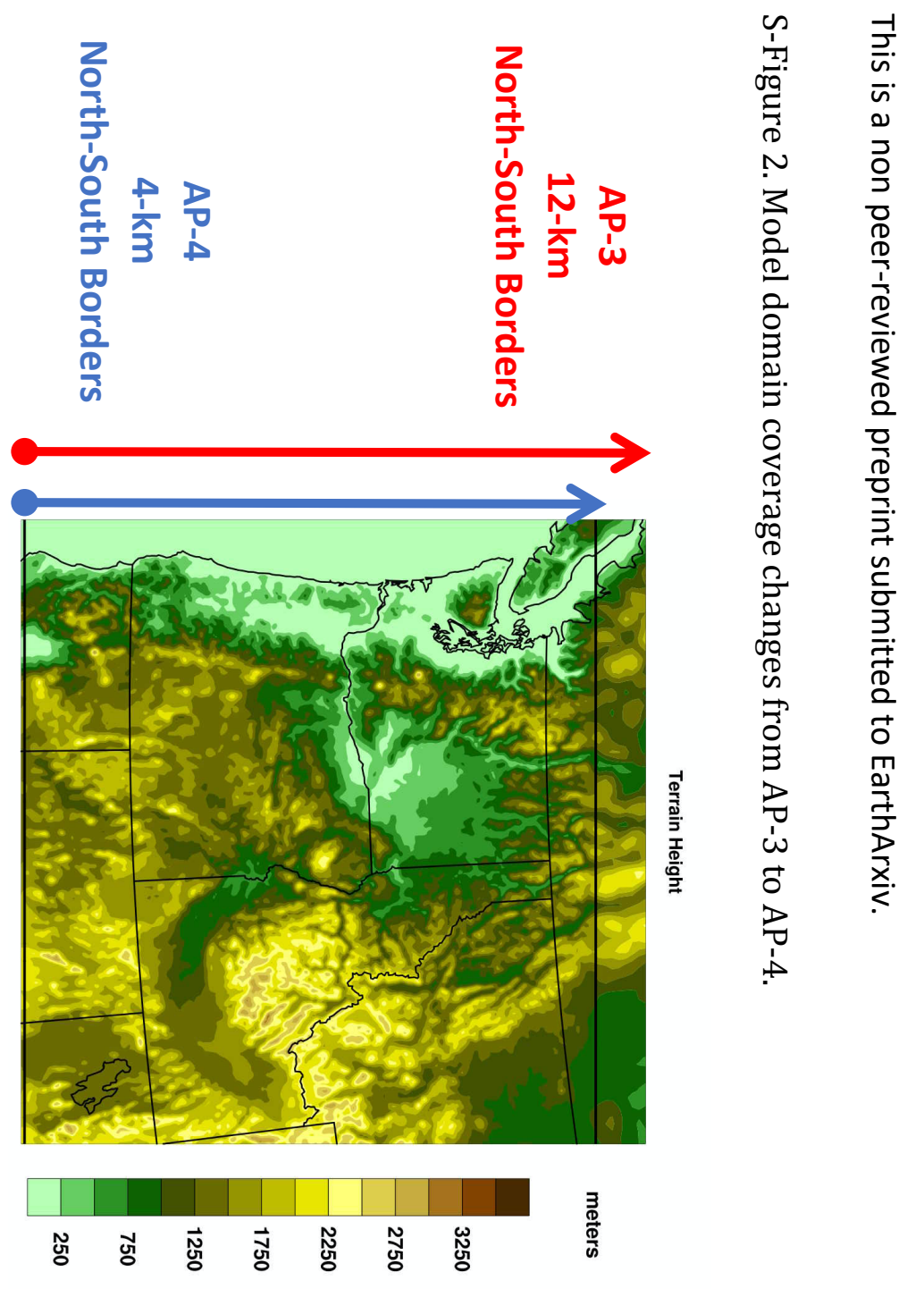



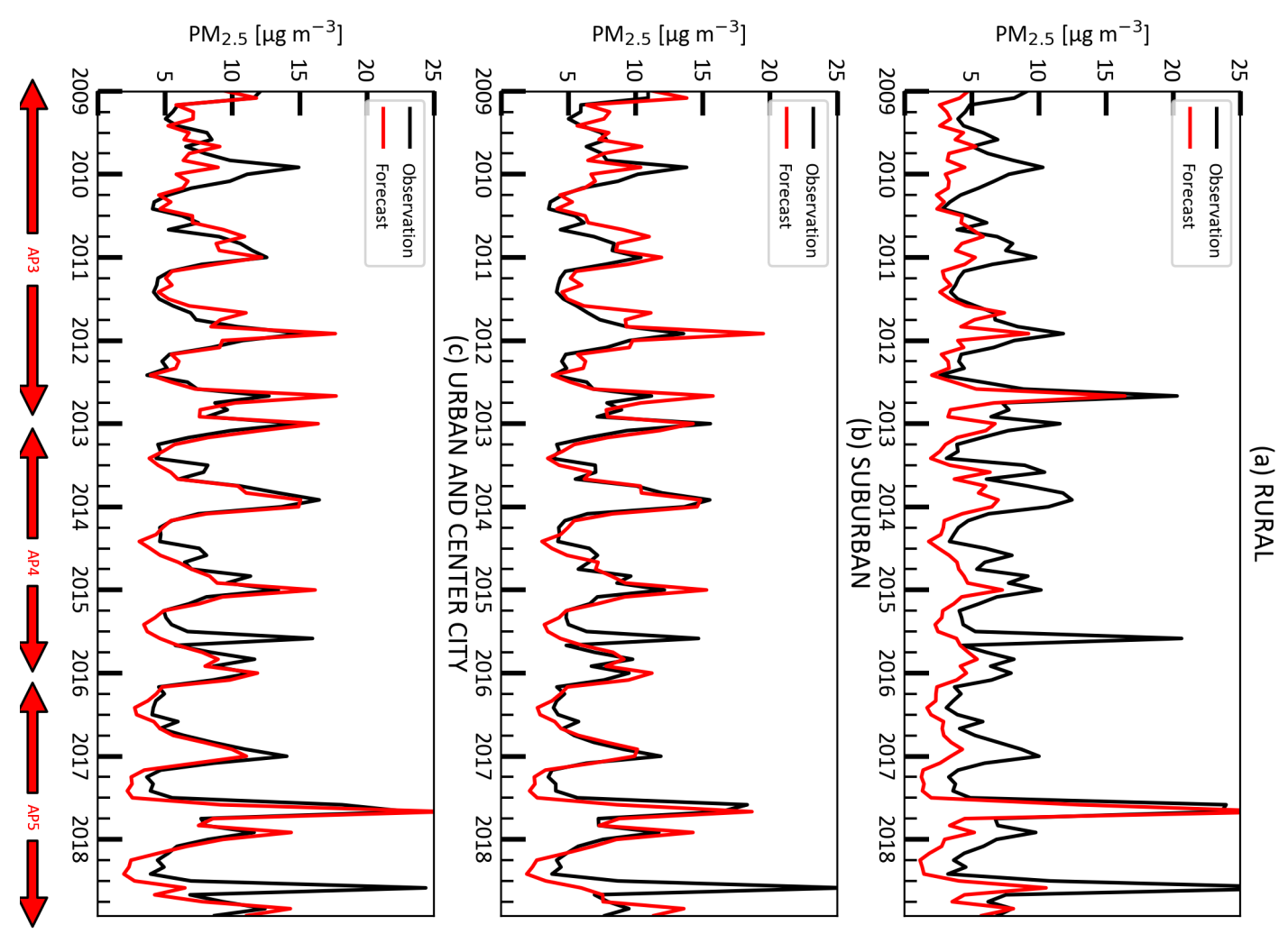

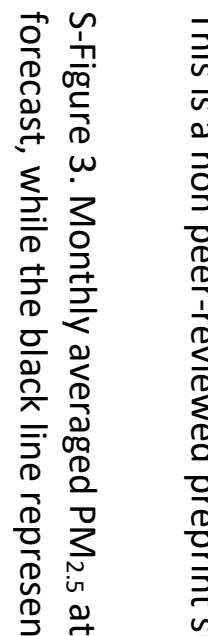

ज芩

을

造

齐步

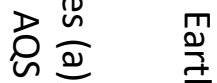

우

के

단

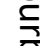

כ

ज.

$\frac{a}{0}$

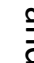

$\omega$

금

要

$\stackrel{n}{\mathbb{D}}$

ล

공

त)

$\overline{\bar{D}}$

용

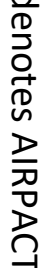



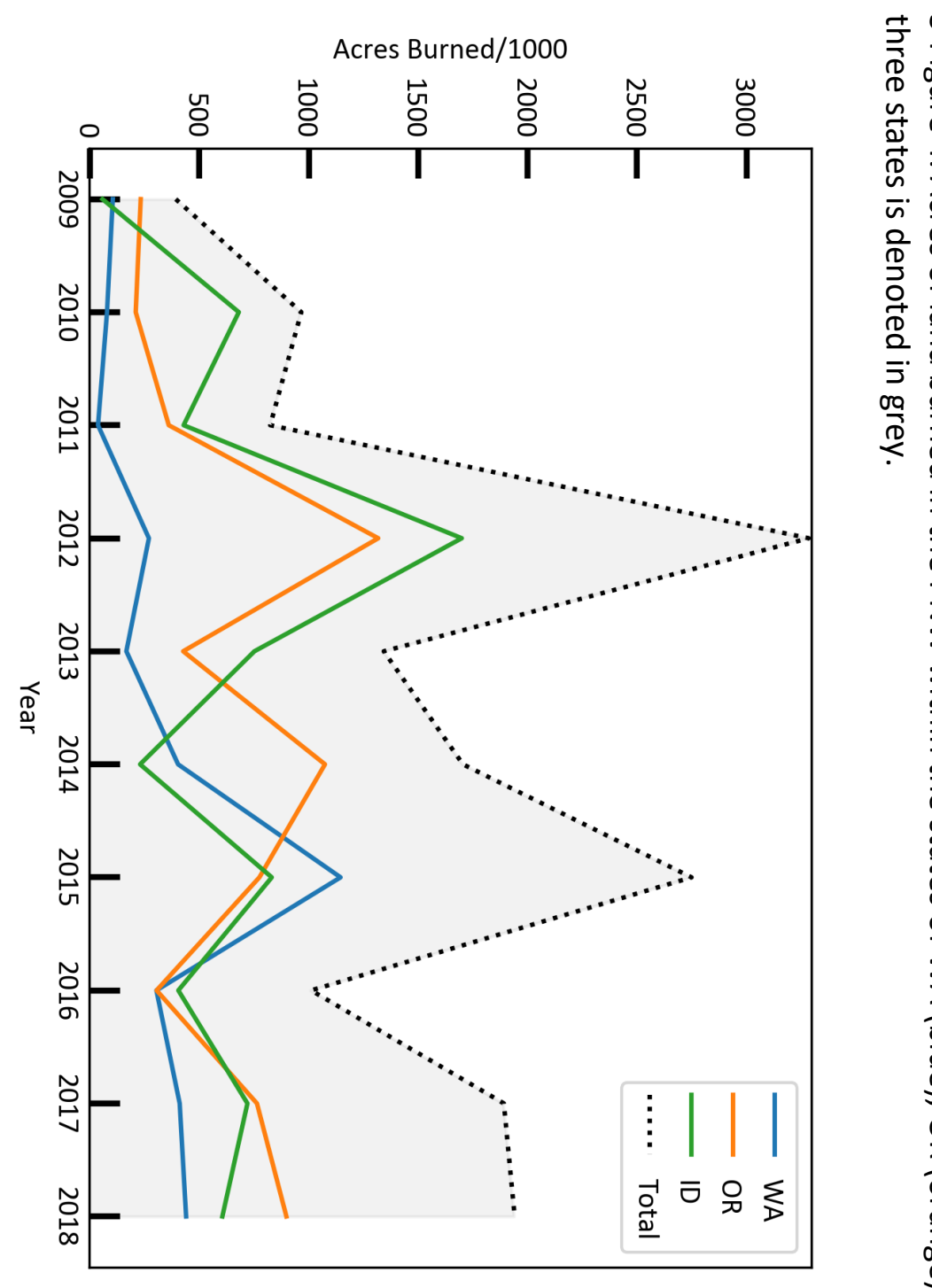

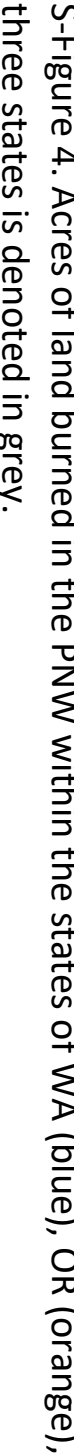

고․

ป

$\rightarrow$ 음

每 